\title{
Petrology and geochemistry of Variscan dykes from the Jáchymov (Joachimsthal) ore district, Czech Republic
}

\author{
Miroslav ŠTEMPROK ${ }^{1 *}$, Thomas SEIFERT², František V. HOLUB ${ }^{1}$, Marta CHLUPÁČOVÁ3 \\ David DOLEJŠ ${ }^{4}$, Jiří K. NOVÁK${ }^{5}$, Edvín PIVEC ${ }^{6}$, Miloš LANG ${ }^{5}$ \\ ${ }^{1}$ Department of Petrology and Structural Geology, Charles University, Albertov 6, 12843 Prague 2, Czech Republic; \\ stemprok@natur.cuni.cz \\ ${ }^{2}$ Institute of Mineralogy, TU Bergakademie, 09596 Freiberg, Brennhausgasse 14, Germany \\ ${ }^{3}$ Boháčova 866/4, 14900 Prague 4, Czech Republic \\ ${ }^{4}$ Bayerisches Geoinstitut, University of Bayreuth, 95440 Bayreuth, Germany \\ ${ }^{5}$ Institute of Geology, v.v.i., Academy of Sciences of the Czech Republic, Rozvojová 269, 16500 Prague 6, Czech Republic \\ ${ }^{6}$ Rajmonova 1196, 18200 Prague 8, Czech Republic \\ * Corresponding author
}

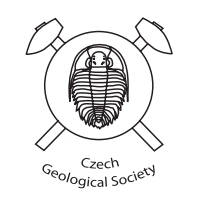

Mafic and silicic dyke rocks, which occur in the Ag-U ore district of Jáchymov (Joachimsthal) in the Krušné hory (Erzgebirge) belong to kersantites, diorite porphyries, and granite porphyries, subordinately to spessartites. Dykes of minettes are located outside the district and penetrate the Nejdek-Eibenstock granitic massif. Mafic and silicic dykes exhibit diverse cross-cutting relationships and form in places composite dykes. Lamprophyres correspond to shoshonitic magmas with high abundances of compatible ( $\mathrm{Cr}, \mathrm{Ni}$ ) and incompatible elements ( $\mathrm{Rb}, \mathrm{Ba}, \mathrm{P})$. All mafic dykes were affected by a postmagmatic alteration manifested by replacement of primary olivine and pyroxenes by amphibole, biotite and chlorite. Granite porphyries crystallized from leucocratic, weakly peraluminous, low-P magmas with moderate enrichments in $\mathrm{Rb}$ and depletions in $\mathrm{Ca}, \mathrm{Sr}$ and $\mathrm{Zr}$. By contrast, diorite porphyries are intermediate rocks containing $62-65 \mathrm{wt}$. \% $\mathrm{SiO}_{2}$ whose geological occurrence and major-element composition suggest origin by magma mixing involving lamprophyric and silicic melts, with simultaneous fractionation of biotite. The $\mathrm{Th} / \mathrm{U}$ ratios in all dyke rocks correspond to chondritic and crustal values and demonstrate that whole-rock uranium contents were neither significantly increased nor affected by contemporaneous mineralization events.

The stable isotope composition has been determined for whole rocks $(\mathrm{O}, \mathrm{C}, \mathrm{S})$ and carbonate minerals $(\mathrm{C}, \mathrm{O})$. Wholerock $\delta^{18} \mathrm{O}$ values range between 1.6 to $7.8 \%$ SMOW and do not show any systematic variations with the rock types. The isotopic composition of carbonates is represented by the following values: $\delta^{18} \mathrm{O}=19.6$ to $25.0 \%$ SMOW and $\delta^{13} \mathrm{C}=-5.7$ to $-9.0 \%$ PDB. The high positive values of $\delta^{18} \mathrm{O}$ of carbonates are in a remarkable contrast to compositions of primary magmatic carbonates and indicate the carbonate formation during low-temperature hydrothermal event(s). Sulphides in kersantites and diorite porphyries yielded $\delta^{34} \mathrm{~S}=0.5$ to $6.6 \%$ CDT, which document crustal in addition to mantle source of sulphur consistent with average value in the Saxothuringian crust ( $5 \%$ CDT). Bulk magnetic susceptibility of dyke rocks shows a general decrease from mafic to silicic magmas in a sequence as follows: kersantites -500 , minettes -350 , diorite porphyries -350 and granite porphyries $-50 \cdot 10^{-6}[\mathrm{SI}]$. Local increases up to $5000 \cdot 10^{-6}[\mathrm{SI}]$ are due to accessory pyrrhotite in kersantites and diorite porphyries. Mafic dykes in the Western Krušné hory (Erzgebirge) are preferentially found within the Jáchymov-Gera tectonic zone and demonstrate spatial focusing of ascending mantle-derived melts. Such pathways may have served for transfer of ore-forming elements on the crustal scale by fluids of diverse origin.

Keywords: lamprophyre, granite porphyry, uranium mineralization, magma mixing, Western Krušné hory/Erzgebirge Pluton Received: February 15, 2008; accepted March 26, 2008, handling editor S. Vrána

\section{Introduction}

Magmatic dykes are common in hydrothermal ore districts related to granitoids and exhibit various spatial and temporal relationships to metallic mineralization (Robb 2004). For example, silicic batholiths are frequently associated with granitic, aplitic and porphyry dykes as well as calc-alkaline lamprophyres (Wimmenauer 1973; Rock 1991). Composite felsic-mafic dykes demonstrate a contemporaneous intrusion of magmas with contrasting compositions, sources of which may have been indepen- dent (e.g., crustal versus mantle). Frequently, bimodal dykes involve calc-alkaline, shoshonitic lamprophyres (Rock 1977; Mitchell 1994), which, in turn, are associated with mesothermal hydrothermal gold deposits (Rock et al. 1989; Ashley et al. 1994) and the dykes serve as an evidence for the mantle origin of gold (McNeil and Kerrich 1986; Wyman and Kerrich 1988; Rock 1991). The genetic relationship between dyke rocks and the origin of ore-bearing fluids has been proposed in numerous other districts as well (Abdullaev 1957; Shchukin 1974; Efremova 1983; Müller and Groves 1997). 

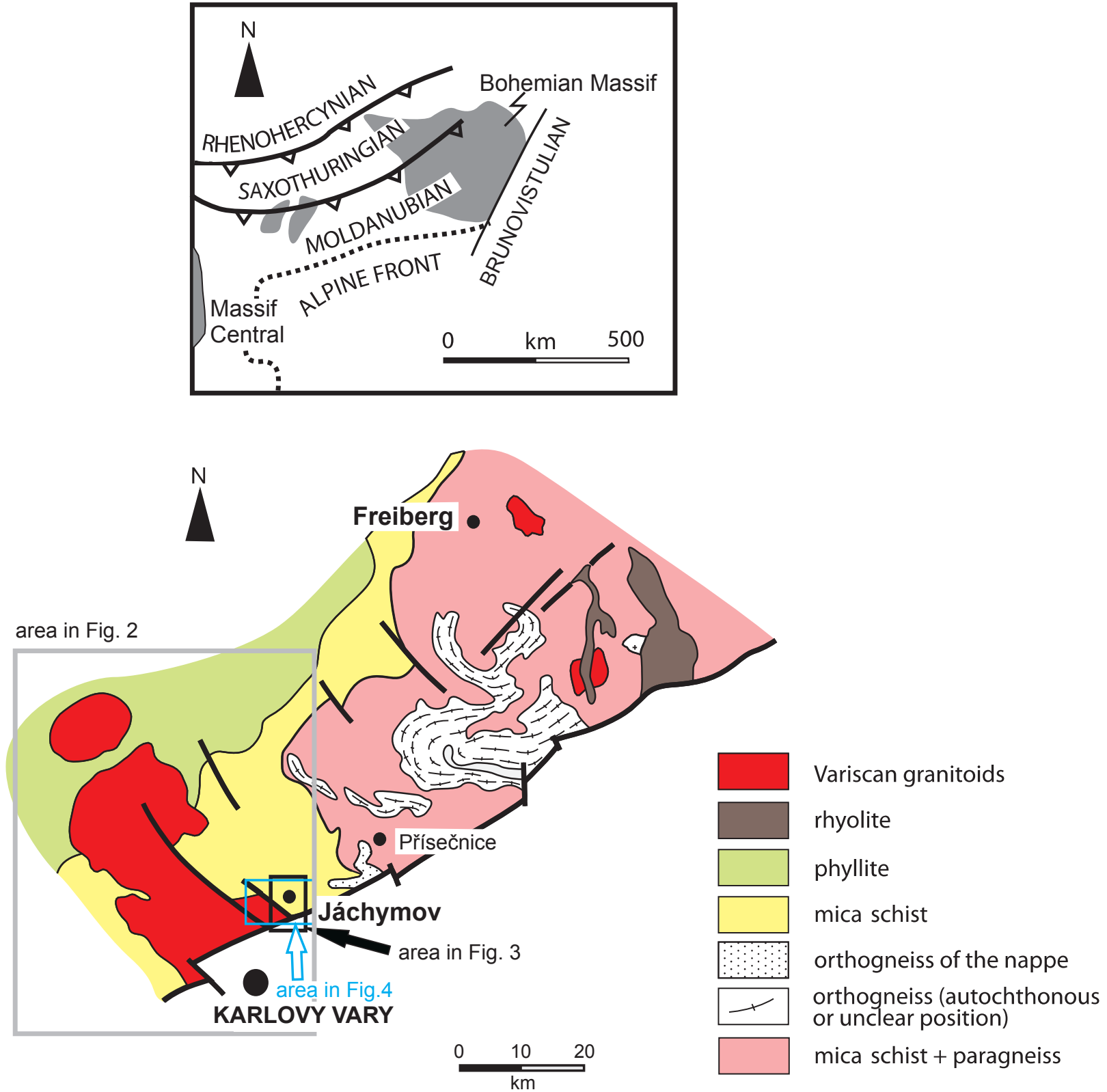

Fig. 1 Simplified geological map of the central part of the Krušné hory/Erzgebirge (adapted from Konopásek et al. 2001).

The connection between occurrences of bimodal dykes in the ore districts and hydrothermal mineralization may be twofold: (1) structural - dyke rocks indicate brittle discontinuities, which may have served as magma and fluid-feeding channels, or (2) chemical - dyke rocks or magmatic fluids may have been the source of metals for hydrothermal mineralization. In addition, bimodal dykes testify to various magmatic sources (crustal vs. mantle) for the parental magmas and their communication in the upper crust at the time and locus of ore mineralization (Rock et al. 1989; Holub and Štemprok 1999).
The presence of dyke swarms can provide important clues in the search for ore components of Variscan mineralizations in the northwestern part of the Bohemian Massif (Kramer 1976) and, in particular, in the metallogenic province of the Krušné hory/Erzgebirge (Štemprok and Seltmann 1994). The genetic link between lamprophyres and mineralization in this magmatic-metallogenic province has been advocated previously (Kramer 1988; Seifert 1999).

This paper presents new geological, petrological and geochemical data from dyke rocks in the Jáchymov (Joachimsthal) area, which is located at the exocontact 


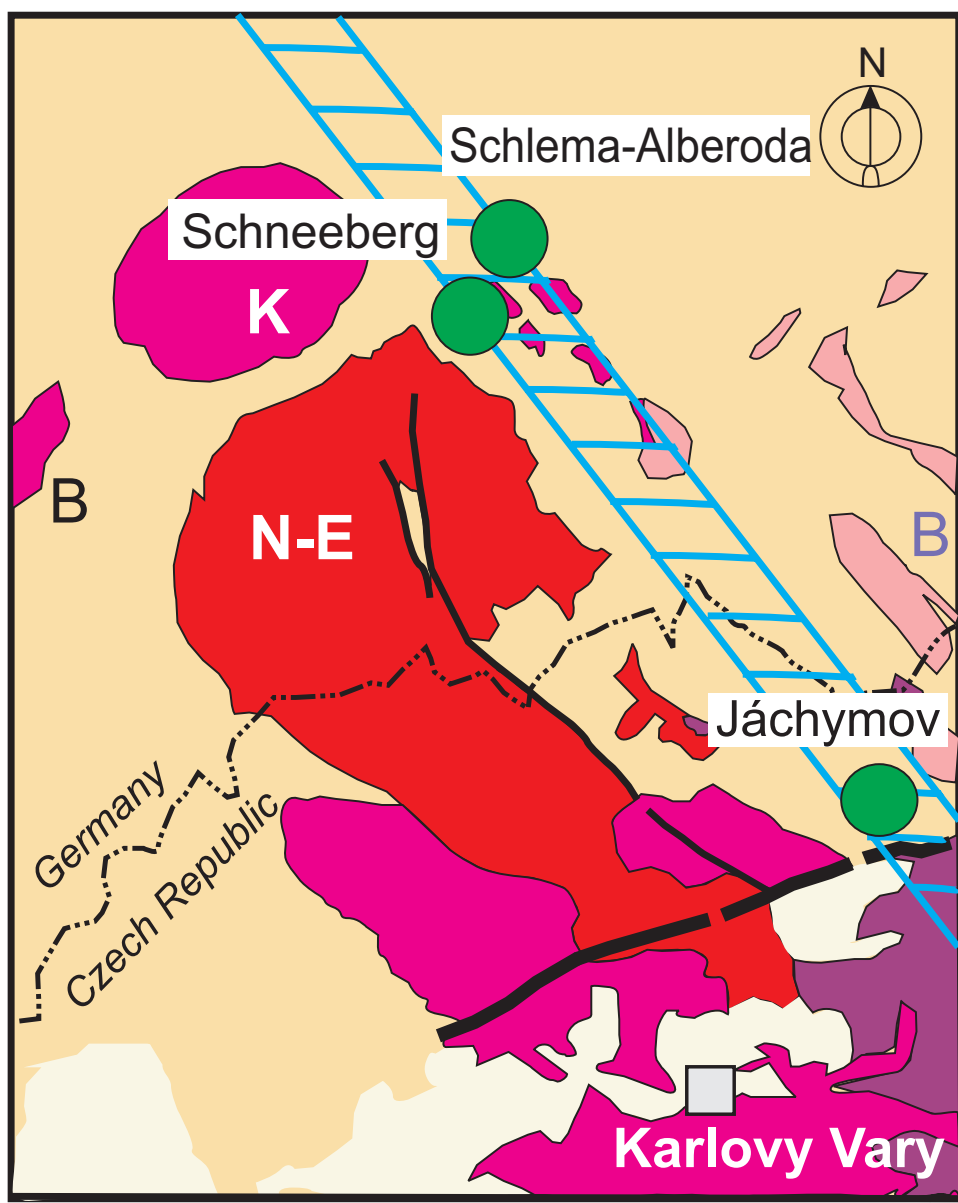

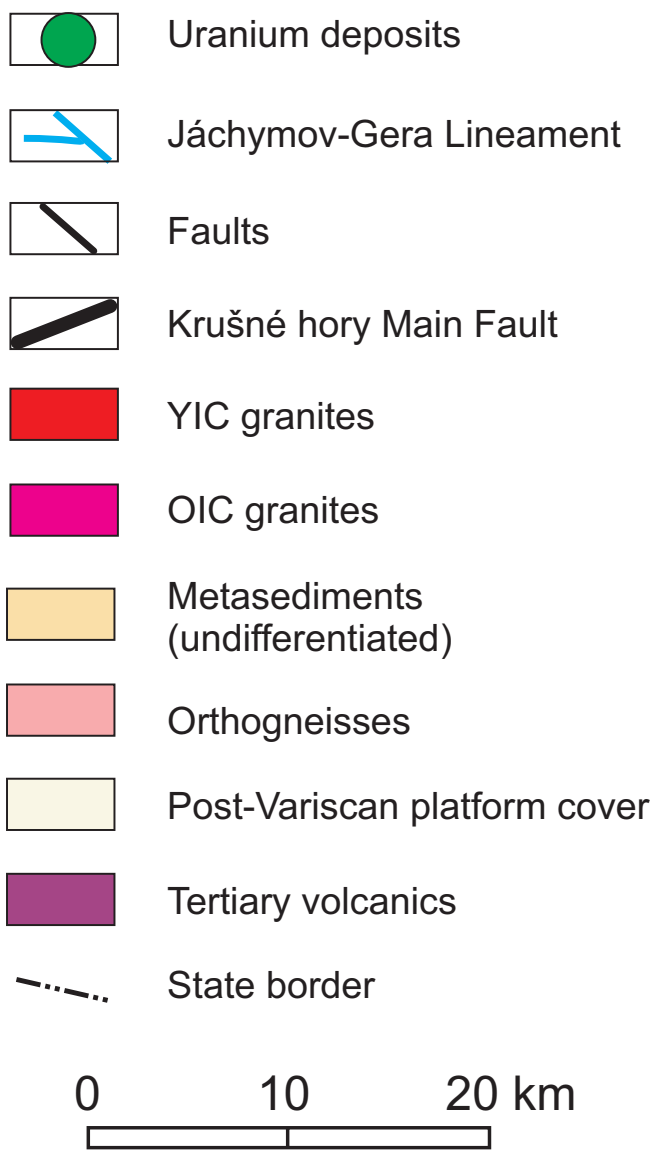

Fig. 2 Simplified geological map of the Western Krušné hory/Erzgebirge Pluton showing two principal Variscan granitic intrusive complexes (Older Intrusive Complex, OIC, and Younger Intrusive Complex, YIC), the Jáchymov-Gera Lineament and the main uranium deposits (based on geological map 1:200 000, sheet Karlovy Vary, Czech Geological Survey 1963, ore deposits by Hösel and Breiter eds, 1995).

N-E - Nejdek-Eibenstock; K - Kirchberg; B - Bergen massifs

of the Western Krušné hory/Erzgebirge Pluton (WKEP) and hosts extensive uranium and bismuth-cobalt-nickel mineralization.

\section{Geological setting}

\subsection{Geological position}

The historical Jáchymov (Joachimsthal) ore district (Majer 2004) is located in the western Krušné hory/ Erzgebirge, in the northwestern part of the Bohemian Massif (Fig.1). The area is known for the outcrops of Late Variscan granites (325-290 Ma; Kempe et al. 2004; Romer et al. 2007) assigned to the WKEP (Fig. 2). This is divided into the Nejdek-Eibenstock massif north of the Krušné hory/Erzgebirge fault and the Karlovy Vary (Carlsbad) massif located to the south (Fig. 2). Granite intrusions build two main intrusive suites: the Older
Intrusive Complex (in further text OIC) (or "Gebirgsgranit" according to Laube 1876) and the Younger Intrusive Complex (further YIC) or "Erzgebirgsgranit" (Laube 1876). This interpretation was accepted in later papers (Lange et al. 1972, Štemprok 1986) but replaced in some studies by a more complex geochemical classification of Förster et al. (1999).

The Jáchymov district has been renowned for its silver, uranium and bismuth-cobalt-nickel mineralization for several centuries. The crystalline complex of the area is part of the Saxothuringian Zone of the Variscan orogen in Europe interpreted as a component of peri-Gondwanan terranes (Murphy et al. 2004). The complex consists of high-grade Proterozoic paragneisses and mica schists as well as medium- to low-grade Lower Palaeozoic mica schists and phyllites (Škvor 1974) (Fig. 1). Pre-Variscan granites intruded at $\sim 550 \mathrm{Ma}$ and $\sim 500-480 \mathrm{Ma}$ (Mingram et al. 2004) in the (meta-) sedimentary complex and were transformed into orthogneisses during Variscan 


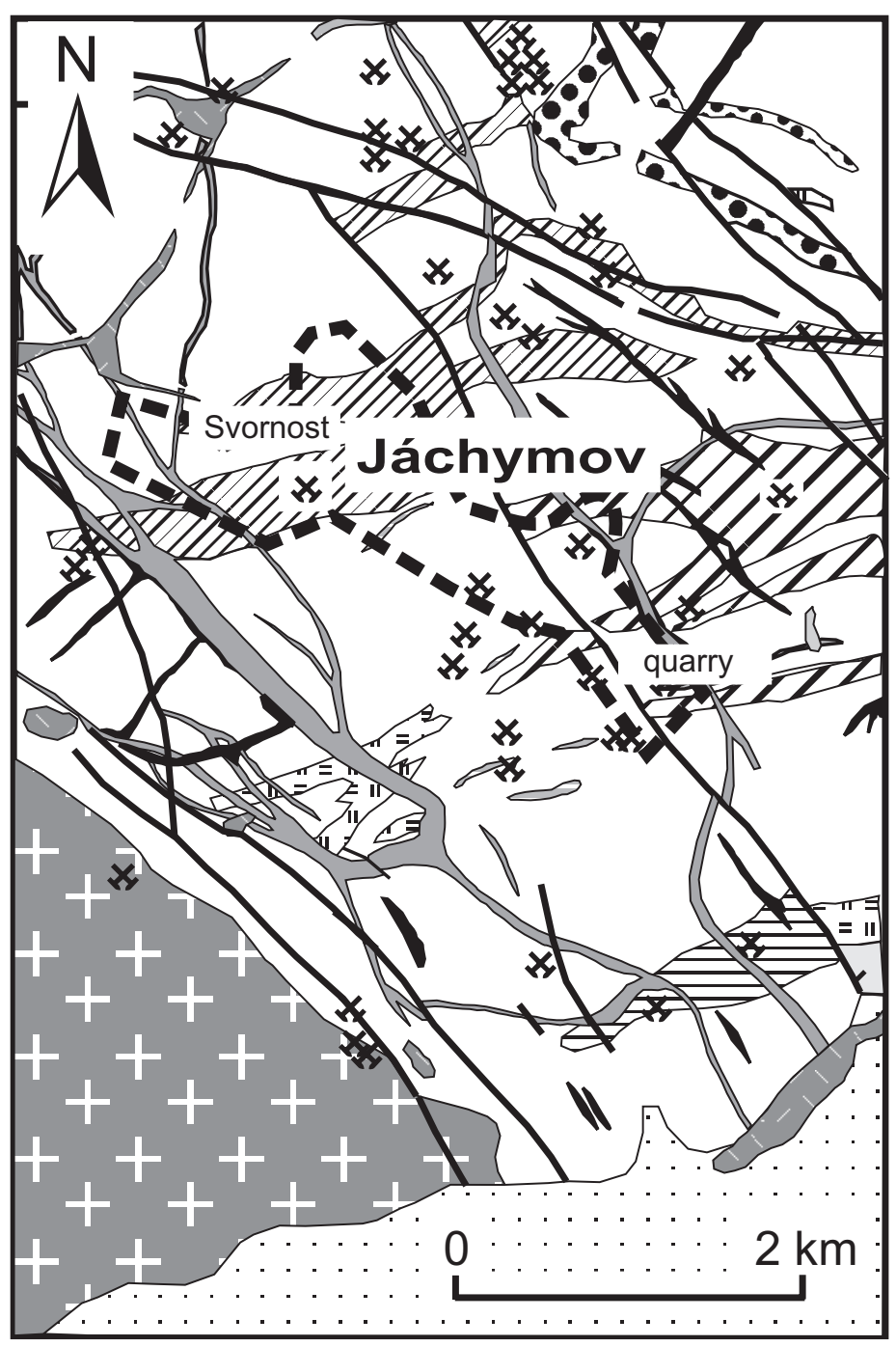

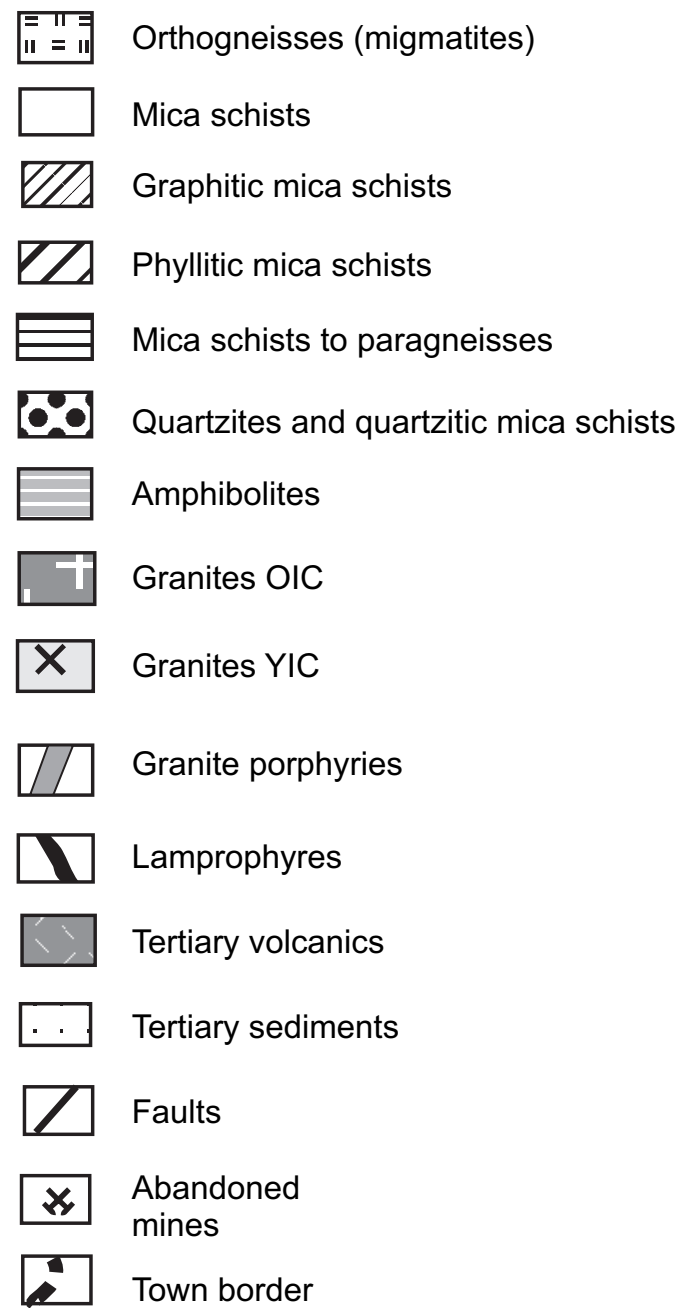

Fig. 3 Detailed geological map of the Jáchymov district (simplified from the map 1:50 000 of the Czech Geological Survey by Škvor and Sattran eds, 1974).

orogeny. The current geological structure is dominated by Variscan thrust tectonics, which led to the juxtaposition of eclogites, orthogneisses and metasedimentary units (Konopásek 1998, Konopásek et al. 2001) (Fig. 1).

Metamorphic rocks in the Jáchymov region are composed of intensely folded mica schists and micaceous paragneisses (Fig. 3). Komínek et al. (1994) distinguished (from the bottom to the top): (1) the Jáchymov Formation c. $1000 \mathrm{~m}$ thick, built up by various mica schists, locally garnet-bearing, with intercalations of calc-silicate rocks, quartzites and amphibolites; (2) the Barbora Formation, which is $700-1000 \mathrm{~m}$ thick, and consists of micaschists, locally with garnet, enclosing intercalations of amphibolites, quartzites and orthogneisses; (3) the Potůcky Formation c. 1000-1500 m thick, made up of phyllites, which enclose amphibolite bodies (Fig. 3). The crystalline complex is underlain by the YIC granites of the WKEP at 200-400 m below the present surface (Komínek et al. 1994). The Pluton roof is flat or weakly undulated (Sattran 1965; Veselý 1986a, b), partly reflecting intrusion into folded metasediments. The western part of the Jáchymov district has been juxtaposed to the OIC granite by NW-trending faults parallel to the Jáchymov-Gera Lineament (Fig. 4).

The metamorphosed sediments are assembled into the Klínovec anticline and its subparallel fold structures. This structure is cross cut by numerous faults, which separate the crystalline complex into several tectonic segments. The central fault appears to be the main structure in the Jáchymov district (Fig. 4). 


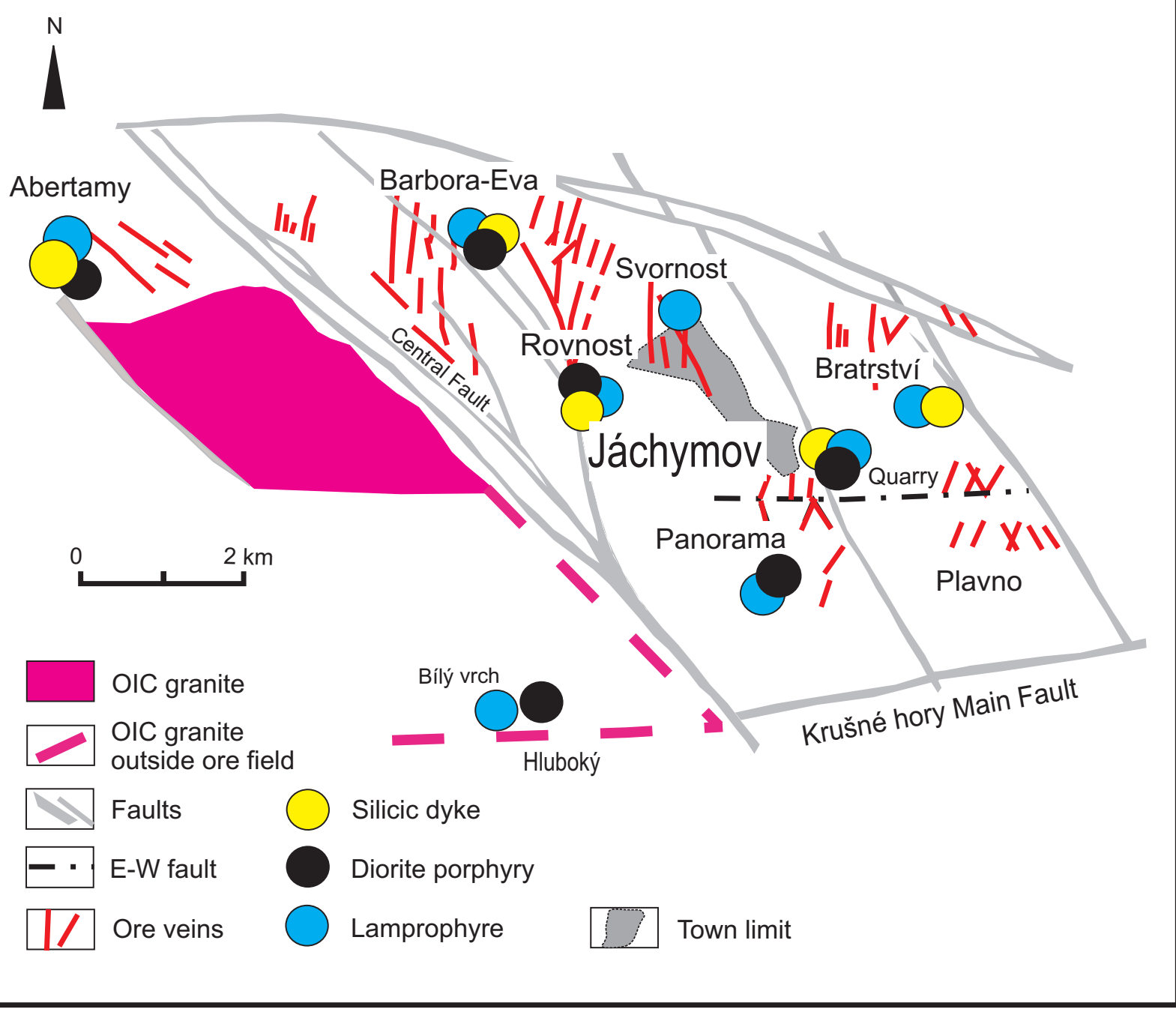

Fig. 4 Schematic map of fault structures in the Jáchymov ore district adapted from Veselý (1986b). The position of the main ore clusters and the sampled association of dyke rocks on the dumps or primary outcrops. The structures of the ore clusters Abertamy and Barbora-Eva at the 630-650 $\mathrm{m}$ a.s.l.; Rovnost, Svornost, Panorama, Bratrství and Plavno at the $450-500 \mathrm{~m}$ a.s.1.

\subsection{Mineralization of the Jáchymov district}

The Jáchymov ore district is located on a major NWtrending lineament, which is about $20 \mathrm{~km}$ wide and hosts other important ore deposits of Schlema-Alberoda and Schneeberg located in Saxony, further to the NW. The Jáchymov district covers $c .45 \mathrm{~km}^{2}$ and is bound by major northwest- and northeast-trending tectonic structures. Mineralized veins have two major strikes: (1) NW to NE with predominant dips to the W, which were historically called „Midnight Veins“ and (2) E$\mathrm{W}$ veins with the main dip to the $\mathrm{N}$ termed „Morning Veins" (Ondruš et al. 2003). The Midnight Veins were the carriers of the main uranium mineralization, whereas the Morning Veins were mined for the Bi-Co-Ni-Ag ores (i.e., the "five-element formation"). The uranium deposit is subdivided into seven vein clusters (Fig. 4; Veselý1986a, b). The uranium ore shoots formed above the hidden granite contact and did not continue into the granites, even though some rare exceptions exist (e.g. the $\mathrm{Y}$ vein at the Rovnost Shaft). The barren interval was located some 150 to $200 \mathrm{~m}$ above the underlying granite surface. Zoubek et al. (1996) explained the occurrence of $U$ mineralization along deep-seated lineaments in the Krušné hory/Erzgebirge by remobilization of dispersed uranium minerals from the Moldanubian protolith below the Saxothuringicum by the fluids of various origins.

Mine workings occasionally intersected $\mathrm{Sn}-\mathrm{As}$ veins or greisens, which are independent of the Ag-U hydrothermal veins (Komínek et al. 1994). The Sn-As mineralization is 
related to the upper surface of the underlying granite pluton, the presence of which may explain greisenization of some mafic dykes situated near the contact of the YIC granites.

The gangue minerals are quartz, carbonates (mainly dolomite), rare fluorite, $\mathrm{Fe}-, \mathrm{Zn}-, \mathrm{Cu}-, \mathrm{Pb}$-sulphides, uraninite, $\mathrm{Co}-\mathrm{Ni}$ arsenides, native bismuth and complex silver ores (Mrňa and Pavlů 1967). The ore mineral sequence covers early quartz-sulphide and carbonateuraninite mineralizations of Variscan age and carbonatearsenide, sulphoarsenide and quartz-hematite mineralization, which is younger ( 150 Ma, Komínek et al. 1994). Baumann et al. (2000) distinguished in the Jáchymov district Variscan and post-Variscan mineralization events. Ore veins were subject to supergene and oxidation processes, which have led to the formation of a variety of secondary minerals (Ondruš et al. 1997).

The dyke swarm occurs at the eastern exocontact zone of the Western Krušné hory/Erzgebirge Pluton in the district. Mafic and silicic dykes do not act as direct hosts of primary uranium mineralization but the uranium shoots are mainly scattered in the mica schists with pyrite impregnations, or are associated with the amphibolites and calc-silicate rocks. The absence of uranium ores in the vicinity of dyke rocks was explained by compact (impermeable) textures of the dykes, their mechanical properties affecting the morphology of veins and unfavourable lithology for ore deposition (Veselý 1986b). On the other hand, both lamprophyres and granite porphyries are frequently intersected by the ore veins (e.g. in ore clusters of Bratrství, Barbora-Eva, Rovnost and Plavno) but a joint occurrence of the ore veins and lamprophyres was observed only exceptionally (e.g., at Panorama), in contrast to other uranium districts in the Krušné hory/Erzgebirge (Seifert 1999, 2007).

\section{Previous studies}

Variscan lamprophyres are frequent in the granitoid areas of the Bohemian Massif, e.g. in its centre, in association with the Central Bohemian Plutonic Complex (Němec 1973) or its northwestern part - in the Krušné hory/Erzgebirge and Fichtelgebirge (Kramer 1976; Štemprok et al. 2000; Seifert 2007). In the latter region the lamprophyres are distributed independently of the late-Variscan granites (Watznauer 1964) but most of their occurrences can be related to outcrops of Variscan plutonic bodies or Late-Palaeozoic volcanic rocks (Seifert 2007). In detail, lamprophyres in the Krušné hory/Erzgebirge are clearly spatially associated with the deep-seated fault zones such as the NW-SE trending Gera-Jáchymov Lineament (Kramer 1976) or associated fault systems (Seifert 1999).

The petrology and geochemistry of lamprophyres in the Krušné hory/Erzgebirge and Fichtelgebirge has been subject of numerous studies initiated by Kramer (1976, 1988) and Seifert (1994). A brief petrological summary of lamprophyres from the Czech part of the Krušné hory/ Erzgebirge was given by Škvor (1974) and those in the eastern Krušné hory by Štemprok et al. (1994). Seifert (1994, 2007) presented detailed accounts of lamprophyre petrology and geochemistry in the Saxonian part of the Central Erzgebirge together with a discussion about the role of lamprophyric magmas in metallogenesis of this region. Micas in lamprophyres have been examined by Kramer and Seifert (1994).

In the western Krušné hory /Erzgebirge lamprophyres mainly occur in the metamorphic envelope of the lateVariscan granites (Kramer 1976; Seifert 2007) and have a form of simple or composite dykes with numerous country rock xenoliths (Baumann and Gorny 1964). The dykes were mostly emplaced before the coarse-grained porphyritic granite of the Eibenstock type, as documented by cross-cutting relationships. In the uranium mines at Rabenberg near Johanngeorgenstadt lamprophyre dykes up to $18 \mathrm{~m}$ thick are intruded by a coarse-grained granite of the Eibenstock type. In contrast, Baumann and Gorny (1964) described a kersantite dyke younger than the coarse-grained porphyritic granite of the Eibenstock type. At the Tannenberg tin deposit, these authors observed an older kersantite intruded prior to greisenization, whereas another lamprophyre was emplaced following the greisenization (see also Seifert 2007). Ačejev and Harlass (1968) interpreted these observations as two lamprophyre series associated with the WKEP, one related to the OIC granites and the other one linked to the YIC granites. This view was adopted by Sattran (1965) to elucidate the sequences of lamprophyres and silicic dykes in the Jáchymov district.

The hypothesis of two lamprophyre suites, which postdate the OIC and YIC granites, respectively, differs from the temporal sequence of lamprophyres recently proposed by Seifert $(1999,2007)$. This author distinguished three stages of lamprophyre intrusions: (1) LD1 emplaced prior to the intrusion of monzogranites (OIC, Eibenstock type); (2) LD2 emplaced between the intrusions of the OIC and YIC granites with associated rhyolitic dykes, and (3) LD3 postdating the Late Variscan granitic magmatism and greisen tin mineralization. In the Central Erzgebirge, emplacement of lamprophyres can only be related to the YIC granites (Seifert et al. 1992; Seifert 1994; Seifert and Kempe 1994). The LD1 kersantites are older than the YIC granites, by which they are intersected in the Sauberg and Vierung districts at Ehrenfriedersdorf. Among lamprophyres in the Annaberg-Marienberg block of the central Erzgebirge (Seifert and Baumann 1994), two types were distinguished: the earlier LD2 (Lauta) and the later LD3 (Pobershau), the latter of which postdates the vein and greisen $\mathrm{Sn}(-\mathrm{W})$ mineralization. 
Lamprophyres in the Jáchymov ore district were described by Sattran (1965) and more recently by Štemprok et al. $(1999,2000)$. The chemical composition of the rock-forming minerals from the mafic dykes in the Krušné hory area, including the Jáchymov district, has been already reported by Pivec et al. (2002). Stable isotopes from mafic dykes in the district were analyzed by Žák et al. (2001). Whole-rock analytical data from several samples were included in a comprehensive study of Seifert (2007).

\section{Dyke rocks in the Jáchymov area}

Distribution of dyke rocks in the Jáchymov area is illustrated in Figs 3 and 4. The strike and dips of many dykes are shown in Fig. 5. In the vicinity of NW-trending contact of the WKEP, the granite porphyries follow the northwestern strike, whereas those emplaced in the phyllite sequences near Abertamy strike E-W (Sattran 1965, 1966).
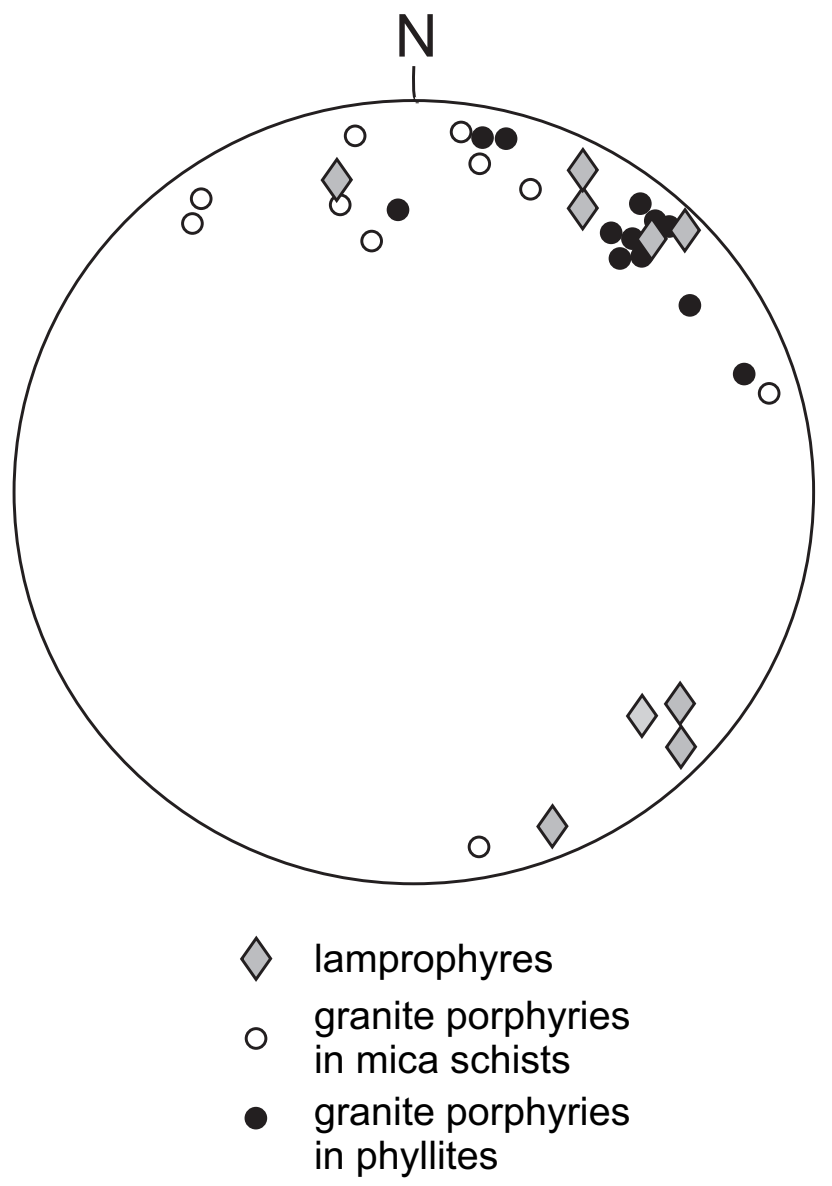

Fig. 5 The poles of the strikes and dips of the dykes in the Jáchymov district according to Sattran (1965).
Granite porphyries occur in several forms: (1) separate dykes, (2) dykes associated with lamprophyres (Fig. 6), or (3) composite dykes consisting of mafic and silicic parts. Granite porphyry dykes exhibit a very irregular course, locally branch, reconnect or pinch out (Fig. 7). A complex branching and connecting of the dykes of granite porphyry near the Pluton contact (Veselý 1986b) suggests an active dyking as the main emplacement mechanism. Dykes of the NE strike are less common. Aplites show both the NW-SE and E-W strikes (Sattran 1965).

The length of granite porphyry dykes ranges from several tens of meters to 3 kilometres and the vertical extent in the mine workings was up to $250 \mathrm{~m}$. Lamprophyre dykes are even more variable in their length and course, the thickness ranges from 0.3 to $10 \mathrm{~m}$, rarely reaches up to $25 \mathrm{~m}$ (Sattran 1965).

The cross-cutting relationships between the mafic and silicic dykes are fairly complex (Sattran 1965; Veselý 1986a, b). In composite dykes, where lamprophyre and granite porphyry occur together, both possible relationships were observed. For example, lamprophyres (NNE) crosscut granite porphyries (NW) at Panorama, lamprophyres and granite porphyries form composite dyke at the Barbora-Eva ore cluster, and granite porphyry (W-E) is intersected by lamprophyre (NW) between the veins 13 and 32 at Bratrství. Between the veins $Z B$ and F3 a crosscutting of a lamprophyre by granite porphyry was observed. Intersections of several stages of granite porphyries are common at the Rovnost I and II mines (Sattran 1965). Similarly, at least two different lamprophyre types intersect at the Boží sen vein. Sattran (1965), based on earlier unpublished petrological work, gave the following sequence of dyke intrusions in the Jáchymov district: (1) early lamprophyres (mainly kersantites), (2) granite porphyries (,quartz porphyries“) with rose or pink colour, (3) younger lamprophyres (mainly spessartites), (4) grey granite porphyries, and (5) aplites. These temporal relationships were interpreted as two dyke sequences of granite porphyries, lamprophyres and aplites, belonging separately to OIC and YIC granites.

On the surface, the joint occurrence of mafic and felsic dykes is exposed in the quarry near the road to the Tomáš mine at the SE margin of Jáchymov (Fig. 8). Here the diorite porphyry intruded a dyke of felsitic granite porphyry (about $20 \mathrm{~m}$ thick); kersantite occurs at the rim of the dyke. Similar porphyritic microgranites were collected on the dumps of the Adam mine.

The dumps of the Rovnost mine provided kersantite with uralitized phenocrysts of clinopyroxene, which must have come from the southern system of ore veins, where a complex lamprophyre dyke associated with the granite porphyry was previously documented (Veselý 1986b). Biotite diorite porphyry with minor uralitized clinopyroxene and ophitic microdiorite from the dumps 


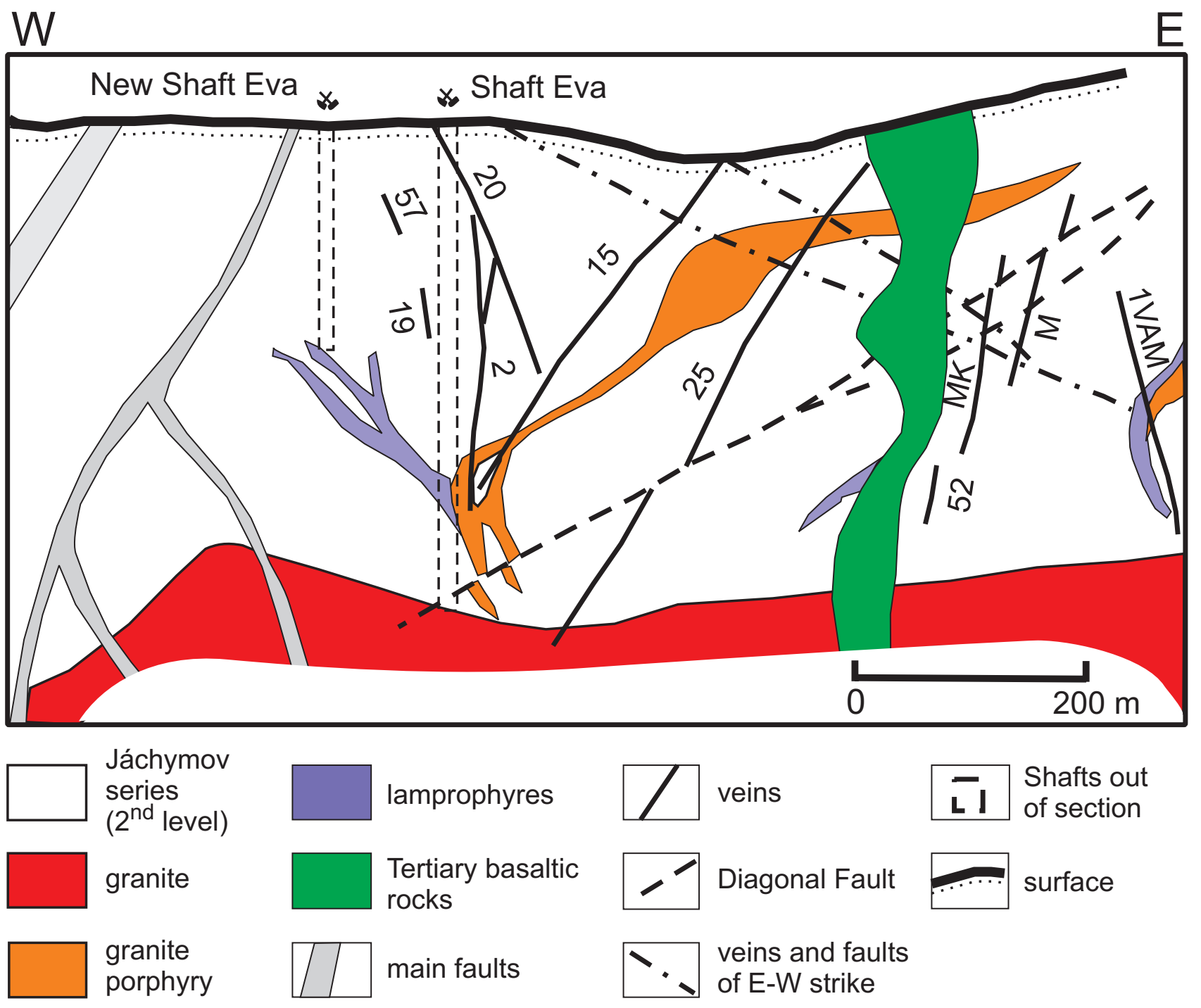

Fig. 6 Schematic section across the ore cluster Barbora-Bratrství, south of the shaft Eva (Veselý 1986b) in the contact zone of the granite. Numbers and letters show the ore vein designation.

of Panorama has been observed in ancient mine workings and identified as a „lamprophyre“ (Veselý 1986b). According to our observations, a fragment of the dark altered lamprophyre was cemented by granite porphyry on the dump of the Eva mine.

\section{Sampling and analytical methods}

Samples for petrographic, geochemical and petrophysical investigation were collected from rock outcrops (Bílý vrch near Hluboký), quarries (Jáchymov), mine dumps (Barbora, Eva, Adam, Rovnost I and Rovnost II) and underground workings (Svornost; Seifert 2007) (Fig. 4). Mine dumps provided unaltered material in the form of blocks ranging from decimetres to metres in size. The re- connaissance study of Štemprok et al. (1999) and Seifert (2007) included the dykes from the Jáchymov quarry.

Samples collected in 1998, each weighing about $2 \mathrm{~kg}$, were crushed in the Institute of Geology of the Academy of Sciences of the Czech Republic (Prague). Majorelement composition was determined by wet chemical methods in the chemical laboratories of the same institute and at the Faculty of Science, Charles University in Prague. Fluorine concentrations were measured after hydropyrolytic decomposition on ion selective electrode and those of chlorine by absorption spectrometry at the Czech Geological Survey (Prague).

Trace-element contents were analyzed by a combination of atomic absorption spectrometry (Cs, Ta, Pb, Li and $\mathrm{Be}$ ) and ICP-MS (Hf, Sn, and REE) at the Faculty of Science, Charles University (Prague) and by X-ray fluo- 

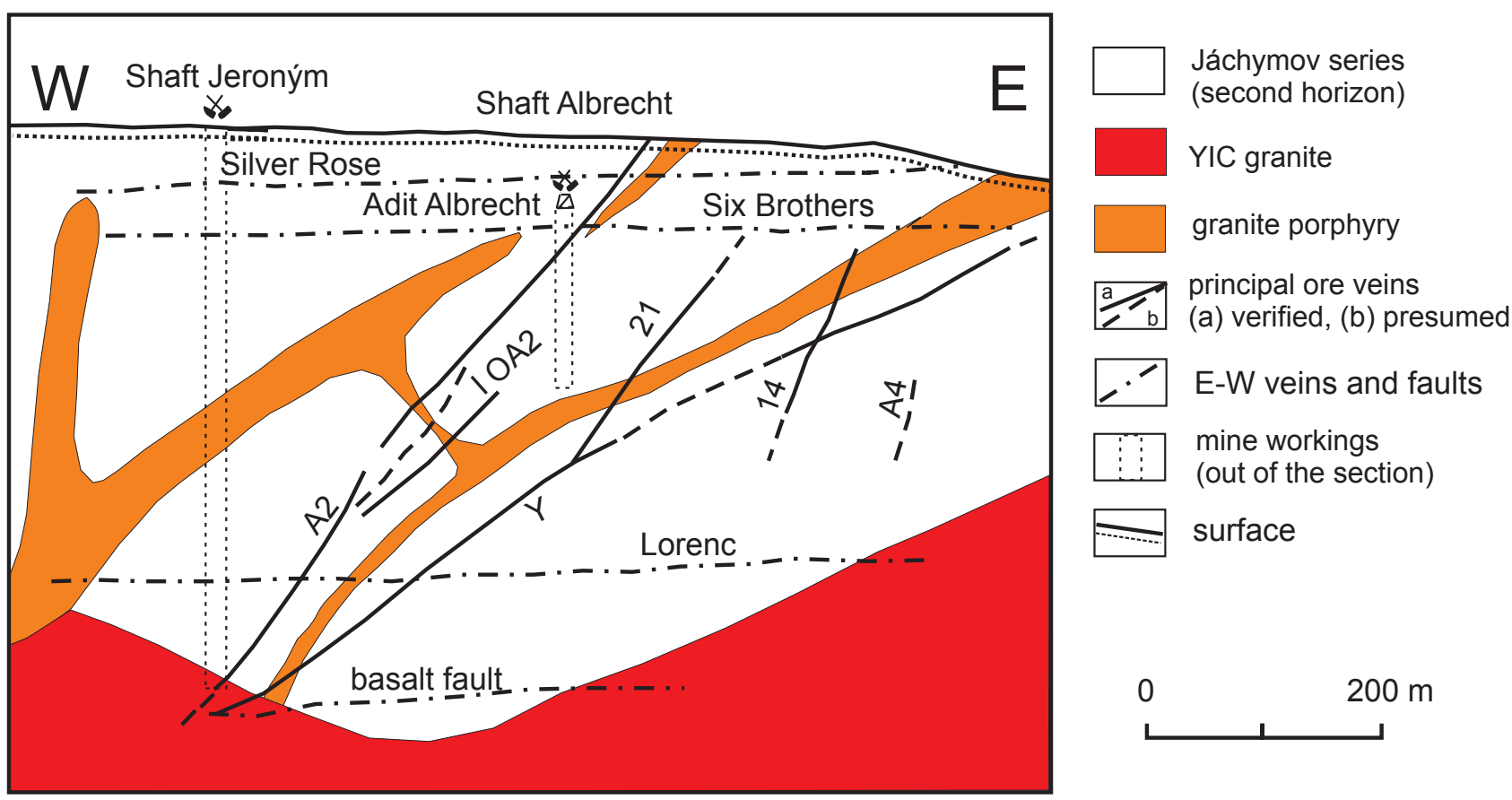

Fig. 7 Schematic cross section through the ore cluster Abertamy, $380 \mathrm{~m} \mathrm{~S}$ of the shaft Jeroným, according to Veselý (1986b). The section shows branching of the granite porphyry dykes at the exocontact of the hidden granite body. Numbers and letters show the designation of ore veins.

rescence (Ba, Rb, Sr, Y, Zr, Ni, Th, Ga, Nb, Zn, V and Cr) at the Faculty of Science of the University of Vienna. The $\mathrm{U}(\mathrm{Ra}), \mathrm{U}$, Th and $\mathrm{K}$ concentrations have been analyzed in a larger set of 65 samples by gamma ray spectrometry at Exploranium $\mathrm{CZ}$ (Brno) using the standards of the International Atomic Agency in Vienna. The details of the method are described in Appendix 1.

Additional samples have been analysed for major and trace elements at the Actlabs Ltd (Ancaster, Canada) and the Sächsisches Landesamt für Umwelt und Geologie (Dresden, Germany) using combination of X-ray fluorescence, ICP-OES, ICP-MS, INAA, gravimetric, infra-spectroscopic, ion-selective electrode and CV-FIMS (Cold Vapour-Flow Injection Mercury System) methods (Seifert 2007).

Stable isotope analyses were carried out at the Czech Geological Survey (Prague). Total concentrations of carbon and sulphur $\left(\mathrm{C}_{\text {tot }}, \mathrm{S}_{\text {tot }}\right)$ were measured by the ELTRA CS 500 analyser. Determination of $\mathrm{CO}_{2}$ was done by coulometric method using Coulomat 7012 and carbon in the carbonate form $\left(\mathrm{C}_{\text {carb }}\right)$ was recalculated from $\mathrm{CO}_{2}$. Gaseous $\mathrm{CO}_{2}$ for measurement of isotopic composition of carbon and oxygen in carbonates has been prepared by reaction with $100 \% \mathrm{H}_{3} \mathrm{PO}_{4}$ in vacuum. Sulphur in the sulphide form was separated chemically by the method similar to that described by Newton et al. (1995). Stable isotope ratios were measured using the Finnigan MAT 251 mass spectrometer. Stable isotope compositions are expressed in the per mil (\%o) notation relative to SMOW/ PDB (O), PDB (C) and CDT (S) standards, respectively. Total error of $\delta^{13} \mathrm{C}$ and $\delta^{18} \mathrm{O}$ in carbonates is equal to \pm $0.1 \%$, the error in $\delta^{34} \mathrm{~S}$ is $\pm 0.2 \%$.

Mineral chemistry of the rock-forming minerals has been analyzed using the JEOL XA 50A electron microprobe in the Institute of Geology of the Academy of Sciences of the Czech Republic in Prague (see Pivec et al. 2002 for analytical details). Mean magnetic susceptibility $\mathrm{Km}$ of selected whole-rock samples was measured on the KLY-3/NRM kappabridge with the JR-5A rotating magnetometer at Agico Ltd. (Brno).

The dependence of magnetic susceptibility on temperature has been studied on the KLY-3S kappabridge in combination with the CS-3 non-magnetic furnace. Details of these methods were given by Hrouda $(1980,1994)$ and Tarling and Hrouda (1993).

\section{Petrography}

\subsection{Lamprophyres}

\subsubsection{Minettes}

All samples of minette were taken in the NW vicinity of Hluboký (a village SW of Jáchymov) (Fig. 4) within biotite granite of the OIC. This minette is of a typical 


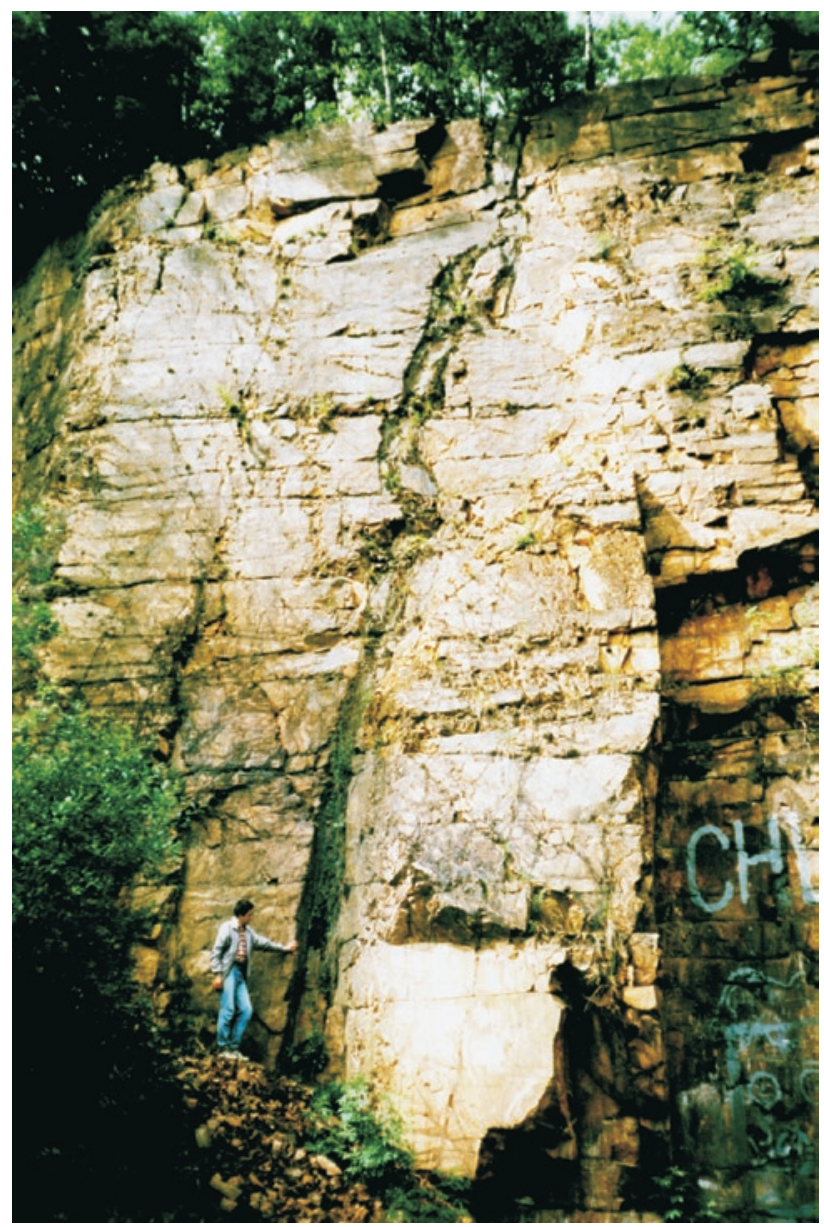

Fig. 8 The northern wall of the quarry in Jáchymov (near the shaft Tomáš) with a dyke of diorite porphyry (centre) intersecting a dyke of granite porphyry (microgranite)

lamprophyre nature by its texture which contains weakly zoned phlogopite/biotite phenocrysts 0.7 to $3.5 \mathrm{~mm}$ in size (Fig. 9a), actinolite clusters after clinopyroxene, and pilitic pseudomorphs after olivine. Deep red phlogopite phenocrysts contain 4.7-5.9 wt. $\% \mathrm{TiO}_{2} ; \mathrm{Mg} /(\mathrm{Mg}+\mathrm{Fe})$ ranges between 0.73 and 0.58 in the cores and 0.62 to 0.59 in the rims. Pilitic pseudomorphs consist mostly of fine-grained assemblage of $\mathrm{Mg}$-rich actinolite and chlorite with other unidentified phases. In some cases, the pseudomorphs are surrounded by biotite flakes. The fine-grained trachytic groundmass comprises clear and very thin K-feldspar laths showing Carlsbad twinning, abundant clouded albite, and biotite flakes compositionally similar to the phenocryst rims. The K-feldspar contains an increased amount of $\mathrm{Ba}$ (up to $1.8 \mathrm{wt} \%$ $\mathrm{BaO}$ ). The most common accessory mineral is fluorapatite accompanied by some titanite and magnetite. All the samples display variable but generally high degrees of alteration producing chlorite, epidote, carbonates and clay minerals. Minette encloses abundant quartz xeno- crysts (10 to 15 grains within each thin section) with actinolitic reaction rims (Fig. 9b) and rarely also gneissic microxenoliths.

\subsubsection{Kersantites}

Kersantites are the dominant lamprophyre type in the Jáchymov district. Highly mafic varieties of kersantite contain variable but often high amounts of pilitic pseudomorphs after olivine phenocrysts or their clusters 0.5 to $3 \mathrm{~mm}$ in size. Pilite is dominated by acicular, almost colourless Mg-rich actinolite with some shredy phlogopite, and frequently also minute inclusions of $\mathrm{Cr}$-spinel and sulphides. The original olivine shape is in some samples well-preserved (Fig. 9c) whereas others contain only irregular patches of the same composition with boundaries disturbed by growth of actinolite needles. Pseudomorphs after clinopyroxene consist of uralitic to homogeneous $\mathrm{Mg}$-rich actinolite ranging to Al-poor (actinolitic) hornblende. In contrast to kersantites from many other areas of the Bohemian Massif, the kersantites studied lack phenocrysts of any primary OH-bearing mineral phase.

The rock matrix of variable grain size $(0.05-0.50$ $\mathrm{mm}$ ), commonly displaying an ophitic-like texture dominated by laths of zoned plagioclase $\left(\mathrm{An}_{70}\right.$ to $\left.A n_{05}\right)$, abundant biotite, and variable amounts of actinolitic pseudomorphs after clinopyroxene rarely preserving the original crystal shape (Fig. 9d). Phlogopite has $\mathrm{Mg} /(\mathrm{Mg}$ $+\mathrm{Fe}) 0.72$ to 0.64 and variable, often conspicuously high titanium contents $\left(\mathrm{TiO}_{2} 2-6\right.$ wt. \%). Sporadically, kersantites may contain relics of prismatic brown amphibole in various stages of replacement by biotite with abundant secondary titanium oxides. Some kersantites contain an increased abundance of interstitial K-feldspar and these were previously classified as kersantite/minette (Seifert 2007).

Inconspicuously porphyritic varieties of kersantite (e.g., samples from the Jáchymov quarry) contain some plagioclase laths of a significantly larger size than the plagioclases in the fine-grained matrix (Fig. 9d), but commonly not larger than the matrix grain-size of a coarsergrained kersantite. When the size contrast between these plagioclase laths and the finer groundmass is more significant, the kersantite passes into diorite porphyry.

Less mafic kersantites (e.g., sample LA 138, Fig. 9e) are poor in fuzzy clusters of actinolite representing poorly preserved pseudomorphs after olivine and/or clinopyroxene phenocrysts. Besides plagioclase some quartz is present in the matrix. Quartz xenocrysts of ,phenocrystic“ size are present in many samples as well.

Acicular apatite is the most common accessory mineral. Oxidic and sulphidic opaque minerals are present locally in highly variable amounts. In the quarry at Jáchy- 

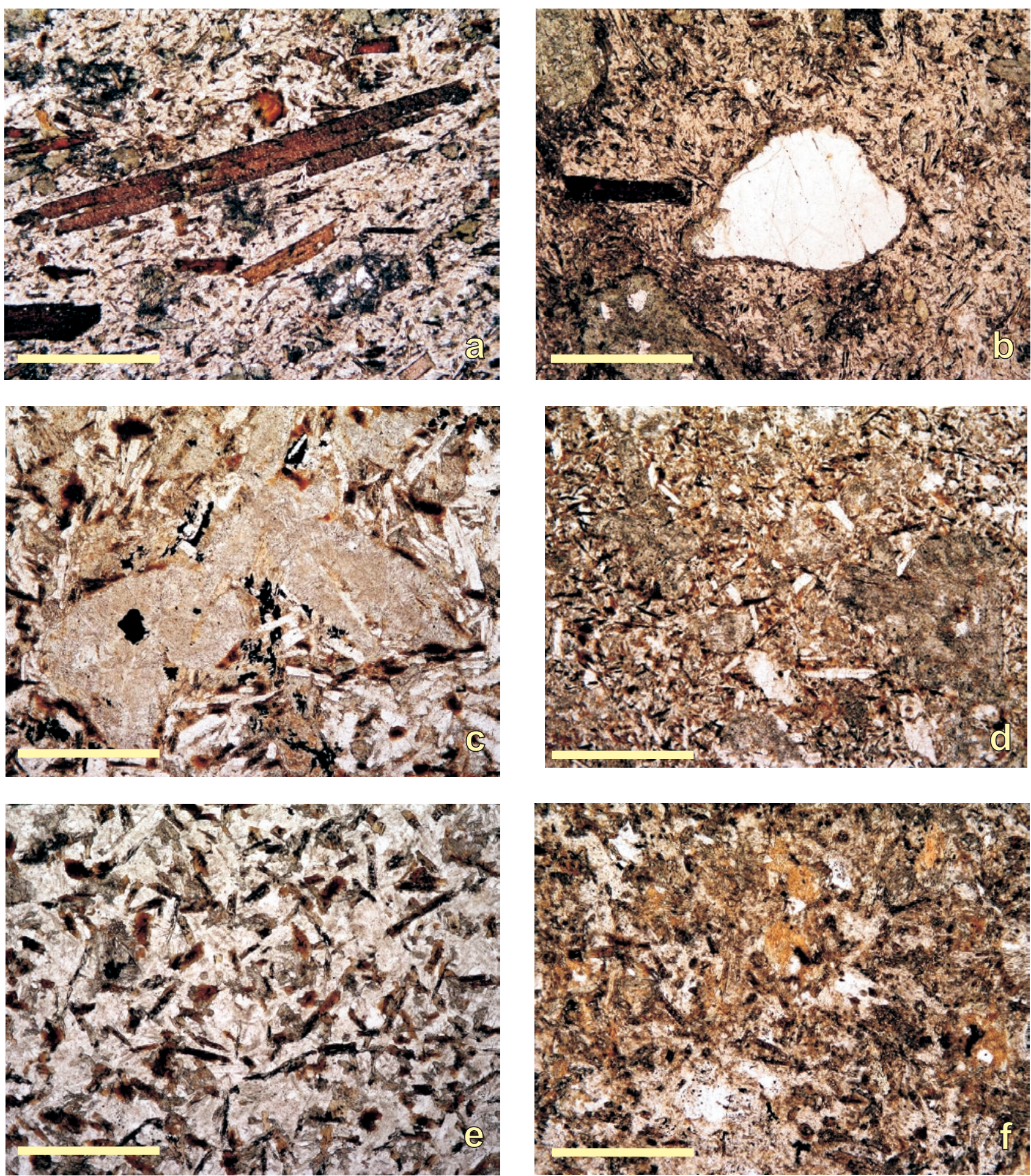

Fig. 9 Photomicrographs (plane polarized light, length of the bar is $1 \mathrm{~mm}$ ) of principal lamprophyre types from the Jáchymov ore district. a - Minette LA 172 with mica phenocrysts (W surroundings of Hluboký); b - Quartz xenocryst in minette LA 131 (NW surroundings of Hluboký); c - Kersantite LA 107 with a cluster of pilitic pseudomorphs after olivine (Jáchymov, quarry near the Tomáš Shaft); d - Kersantite LA 108 (Jáchymov, quarry near the Tomáš Shaft); e - Less mafic kersantite LA 138 (Jáchymov, dump of the Eva mine); f - Spessartite LA 182 (NW of Jáchymov, southern dumps of the Barbora mine) 

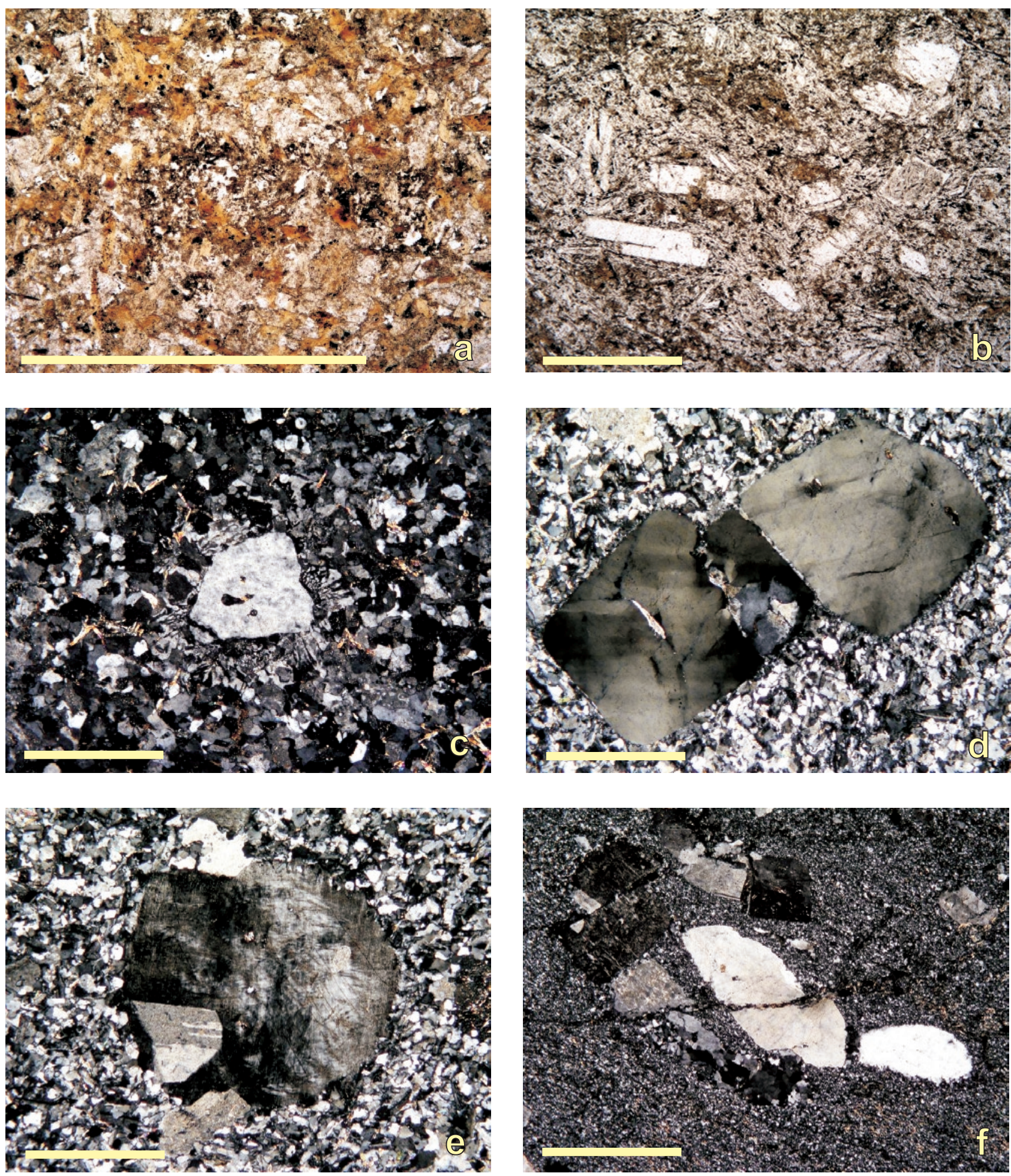

Fig. 10 Photomicrographs of various dyke rocks (// - plane polarized light; $\mathrm{X}$ - crossed nicols; length of the bar is $1 \mathrm{~mm}$ ). a - Secondary dark micas in spessartite LA 182, // (dump of the Barbora mine, NW of Jáchymov); b - Diorite porphyry LA 109 from the dyke intruding the phenocryst-poor granite porphyry, // (Jáchymov, quarry at SE margin); c - Phenocryst-poor granite porphyry (microgranite) LA 110B, rare phenocryst of quartz with micrographic rim, X (Jáchymov, quarry near the Tomáš Shaft); d - Granite porphyry LA 147 with quartz phenocrysts showing strong undulatory extinction, X (Jáchymov, dump of the Adam mine); $\mathbf{e}$ - ditto, small phenocryst of microcline partly enclosing albitic plagioclase crystals; $\mathbf{f}-$ Granite porphyry LA 149 with deformed quartz and feldspar phenocrysts and aphanitic/felsitic groundmass, X (Jáchymov, dump of the Adam mine) 
mov, parts of the kersantite dyke are impregnated by pyrrhotite with some pyrite and small amounts of other ore minerals, including ferrocobaltite. Ferrocobaltite intergrowths with actinolite aggregates suggest that the nickel-cobalt mineralization is younger than postmagmatic (deuteric) uralitization.

\subsubsection{Spessartites}

Spessartite occurrences are subordinate (Sattran 1965) present namely in the central part of the Jáchymov district. The spessartite samples studied were found on dumps of the former mine Barbora. The samples examined are fine-grained with $\mathrm{Mg}$-actinolite clusters representing pseudomorphs after clinopyroxene \pm olivine (?) phenocrysts (Fig. 9f). Primary magmatic amphibole only rarely reaches the size of phenocrysts and commonly is restricted to the matrix.

The matrix texturally similar to kersantites comprises amphibole, plagioclase (labradorite to oligoclase) \pm K-feldspar and variable amounts of phlogopite-biotite. Thin columns to needles $(0.1-0.5 \mathrm{~mm}$ in length) of reddish brown to brown amphibole are Ti- rich and Si-poor and their composition corresponds to titanian magnesiohastingsite up to kaersutite with more than 0.5 atom of Ti per formula unit (Pivec et al. 2002). These amphiboles are partly replaced by greenish to almost colourless magnesiohornblende and actinolite. Much more common is, however, the replacement by Ti-rich phlogopite ranging to biotite that may in places represent a dominant mafic mineral. The samples from the Barbora mine (LA 119 and LA 182) contain also patches of very fine greenish brown Li-bearing dark mica associated with quartz and minute grains of topaz and very fine-grained aggregates of light foxy to orange mica (Fig. 10a), replacing pilitic pseudomorphs. Apatite, ilmenite and magnetite are the accessory minerals.

\subsection{Diorite to granodiorite porphyries}

Diorite porphyries are porphyritic fine-grained mesocratic rocks of lamprophyric appearance. They typically contain small tabular phenocrysts of plagioclase (1-1.5 $\mathrm{mm}$ ) accompanied by variable amounts of pseudomorphs after mafic phenocrysts (Fig. 10b). Plagioclase composition ranges from $\mathrm{An}_{60}$ to $\mathrm{An}_{15}$. In more altered samples, primary plagioclase is totally replaced by albite (e.g., Hluboký).

The fine-grained matrix does not significantly differ from that of kersantite. The major constituents are plagioclase and biotite in thin laths and platelets, usually also secondary lightly greenish actinolite in small clusters. Relics of primary brown amphibole are rare. Diorite por- phyries contain low amount of quartz and some of them also subordinate $\mathrm{K}$-feldspar (sometimes with increased $\mathrm{Ba}$ contents). Apatite and opaque minerals are common accessory constituents. Secondary alteration products are chlorite, sericite, kaolinite, carbonates, hematite and very rare prehnite.

\subsection{Deuteric and postmagmatic alterations of mafic and intermediate dykes}

Deuteric to early postmagmatic alterations of primary magmatic minerals in lamprophyres and diorite porphyries are pervasive and show no relationships to fracture systems. Typical of lamprophyre dykes is total pilitization of olivine phenocrysts and amphibolization of clinopyroxene (uralitization or replacement by homogeneous Mg-actinolite to Al-poor magnesiohornblende). Chloritization of biotite and origin of epidote are common in minette and diorite porphyry. In the area built by granites of the OIC in surroundings of Hluboký the postmagmatic alterations resemble those typical of mafic dykes in general.

Another type of alterations was found in the lamprophyre and diorite porphyry dykes occurring in the area built by metamorphic rocks above the upper contact of the YIC granite Pluton. For these dykes biotitization and lack of chloritization are characteristic. Magmatic Tirich (brown) amphiboles are partly, and in places totally, replaced by reddish brown biotite containing abundant secondary Ti-minerals. Groundmass of many dykes contains significant amounts of disseminated fine-grained biotite that occasionally forms also veinlets attacking plagioclase crystals and quartz xenocrysts.

In some lamprophyres occur patches containing clusters of very fine dark mica displaying various pleochroic colours (deep greenish brown at maximum absorption). This mica classified as Li-bearing one is associated with subhedral grains of quartz and minute topaz crystals. Fluorite may also be present in these rocks. Presence of these minerals is characteristic of greisenization, and the mineral association is similar to that observed in mafic dykes at Krupka in the eastern Krušné hory (Novák et al. 2001).

Some secondary mica occurs as fine-grained, light orange-brown aggregates in lamprophyres, replacing the original pilitic pseudomorphs after olivine and less frequently also actinolitic clusters after clinopyroxene. The presence of more than one type of secondary dark mica is typical especially of spessartites (e.g., from the Barbora mine, samples La 119, 182) (Fig. 11). Some samples are affected by biotitization s.l., to such an extent that their original petrographic nature can hardly be determined with certainty (e.g., sample LA 113). 


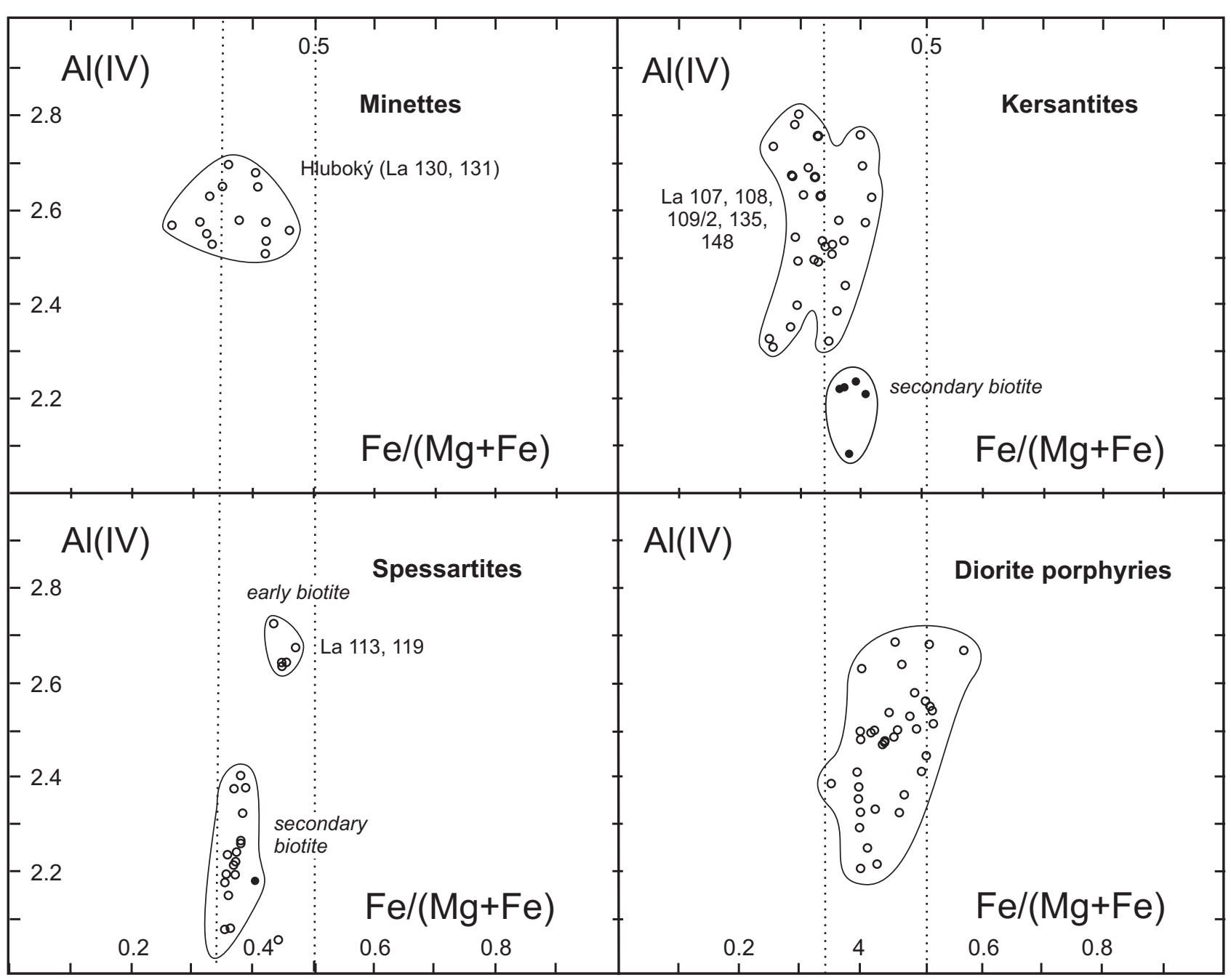

Fig. 11 The composition of biotites of the lamprophyres and diorite porphyries from the Jáchymov ore district adapted from Pivec et al. (2002).

\subsection{Silicic dyke rocks}

\subsubsection{Phenocryst-poor granite porphyry (microgranite)}

This variety of felsic rocks forms a dyke c. $20 \mathrm{~m}$ thick, well exposed in the quarry SE of Jáchymov. Similar rocks were found also at dumps of former uranium mines. Megascopically it is a light grey, pinkish (mostly on weathered surfaces), fine-grained rock almost lacking phenocrysts observable by naked eye.

It shows subhedral equigranular and in some parts also micrographic texture with rare phenocrysts ( 1 to 5 crystals within a thin section) of quartz and feldspars. The phenocrysts of quartz $(0.5-3.5 \mathrm{~mm})$ are euhedral to drop-like and may form small clusters (Fig. 10c). Alkali feldspars form individual tabular crystals, which are occasionally twinned. Aggregates of 3T-muscovite are locally accompanied by chlorite and this suggests the formation by alteration of rare biotite phenocrysts.

The rock matrix $(0.1-0.2 \mathrm{~mm})$ consists of quartz, sodic plagioclase (ordered albite to oligoclase), xenomorphic $\mathrm{K}$-feldspar, and low amounts of muscovite. Topaz, fluorite, ilmenite and magnetite are present as rare accessory minerals. Secondary minerals are represented by sericite, kaolinite, hematite and chlorite.

\subsubsection{Granite porphyries rich in phenocrysts}

Granite porphyries differ from the previous microgranite variety by much higher abundance and greater size of phenocrysts. Formerly, also granodiorite and syenite porphyries were described from the area (e.g., Sattran 1965 and internal mine reports. However, using the recent classification of igneous rocks (Le Maitre et al. 2002) 
all the felsic porphyries we have studied correspond to granite composition.

Quartz phenocrysts are either round with embayments of the groundmass or occur as angular grains and polygranular aggregates occasionally with a strong undulatory extinction (Fig. 10d). Plagioclase (oligoclase) forms thick tabular crystals $(1.0-1.5 \mathrm{~mm})$ or has accumulated as several grains (occasionally with K-feldspar). The K-feldspar phenocrysts are irregular to almost euhedral, 1 to $10 \mathrm{~mm}$ in size (Fig. 10e). In some dykes, phenocrysts of perthitic $\mathrm{K}$-feldspar show overgrowths extending into the groundmass. Rims of secondary albite on the K-feldspar phenocrysts suggest subsolidus unmixing or weak albitization. The rock matrix displays highly variable grain size and consists of quartz, K-feldspar, plagioclase (oligoclase), chloritized biotite and muscovite. Biotite occurs as individual flakes or aggregates, which are often completely chloritized and contain inclusions of secondary titanite. Both the biotite and secondary chlorite are significantly richer in iron compared to those in lamprophyres and diorite porphyries. Composition of muscovite overlaps with that of hydrothermal origin (Štemprok et al. 1999).

Some samples of granite porphyries with very finegrained (felsitic/aphanitic) matrix show distinct fluidal textures defined by arrangement of feldspars and sericite into bands. This variety found on the dumps probably comes from marginal parts of granite porphyry dykes. Accessory phases are represented by topaz, apatite, zir- con, ilmenite and (secondary?) titanite. Some samples contain abundant hematite pigment or are crosscut by quartz or carbonate veinlets.

\subsubsection{Aplites}

Aplites are fine- to very fine-grained equigranular rocks frequently occurring as dykes in the Krušné hory Metamorphic Complex in the vicinity of the granitic bodies (Škvor 1974) or intersecting various granitic intrusions (Štemprok et al. 1996). In contrast to granite porphyries, aplite dykes show constant dyke thickness, straight contacts with wall rocks, lack phenocrysts and have a very fine-grained matrix. We have not studied them in the ore district, from which they were reported in the literature.

\section{Whole-rock geochemistry}

We present geochemical data for 23 samples in Tabs $1-3$.

\subsection{Major elements}

Whole-rock concentrations of $\mathrm{SiO}_{2}$ range between 50.3 and 56.9 wt. \% in lamprophyres, $62.6-64.8$ wt. $\%$ in diorite porphyries, and $73.7-75.1$ wt. \% in granite porphyries

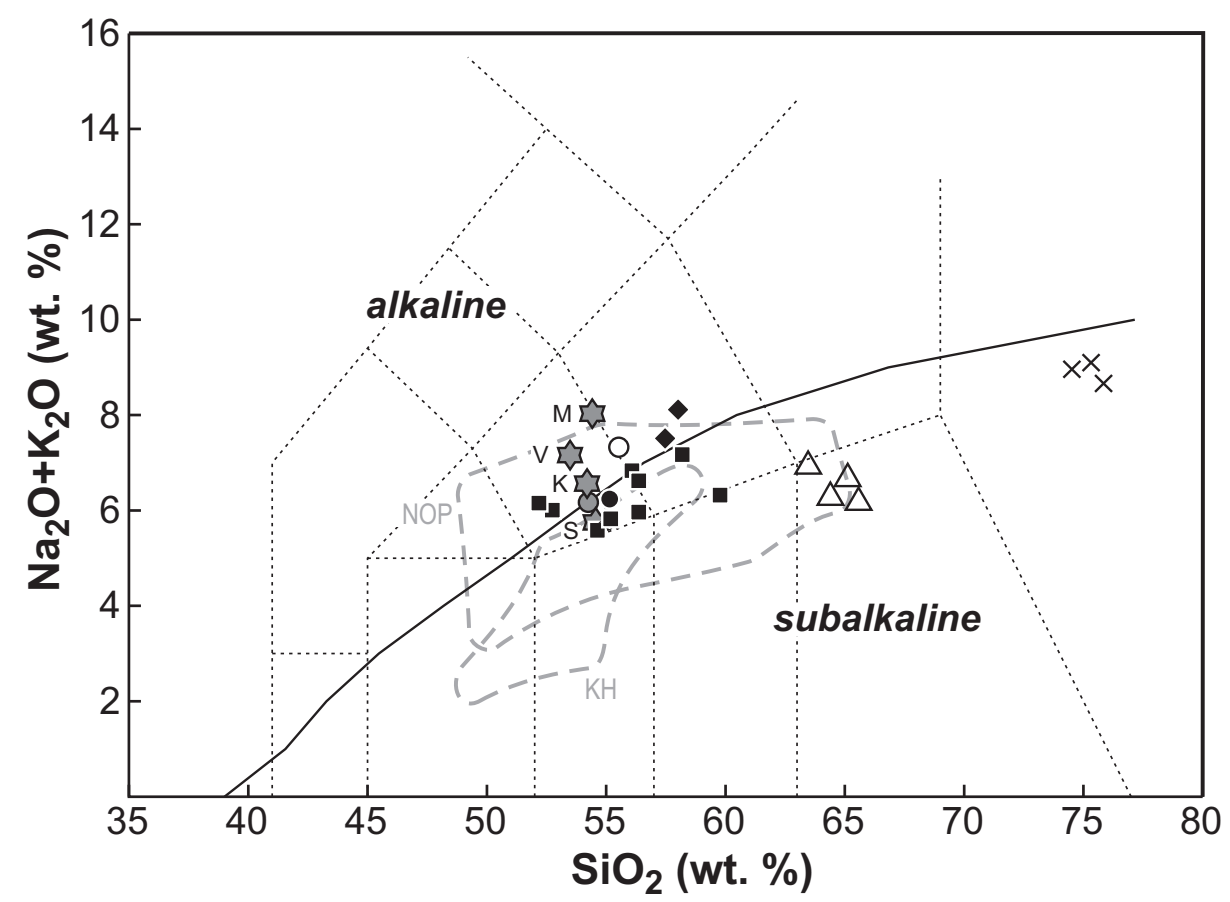

- minettes

- kersantites

- spessartites

- altered lamprophyres

$\triangle$ diorite porphyries

$\times$ granite porphyries

average lamprophyres average calc-alkaline lamprophyre

Fig. 12 The total alkalies versus silica (TAS) diagram of the dyke rocks from the Jáchymov ore district. Average compositions of calc-alkaline lamprophyres are from Rock (1991) (M - minette, S - spessartite, V - vogesite, K - kersantite), NOP - field of redwitzites of the Northern Oberpfalz after Troll (1968) and Siebel (1993), KH - field of redwitzites from the Krušné hory (Kováríková et al. 2007). 


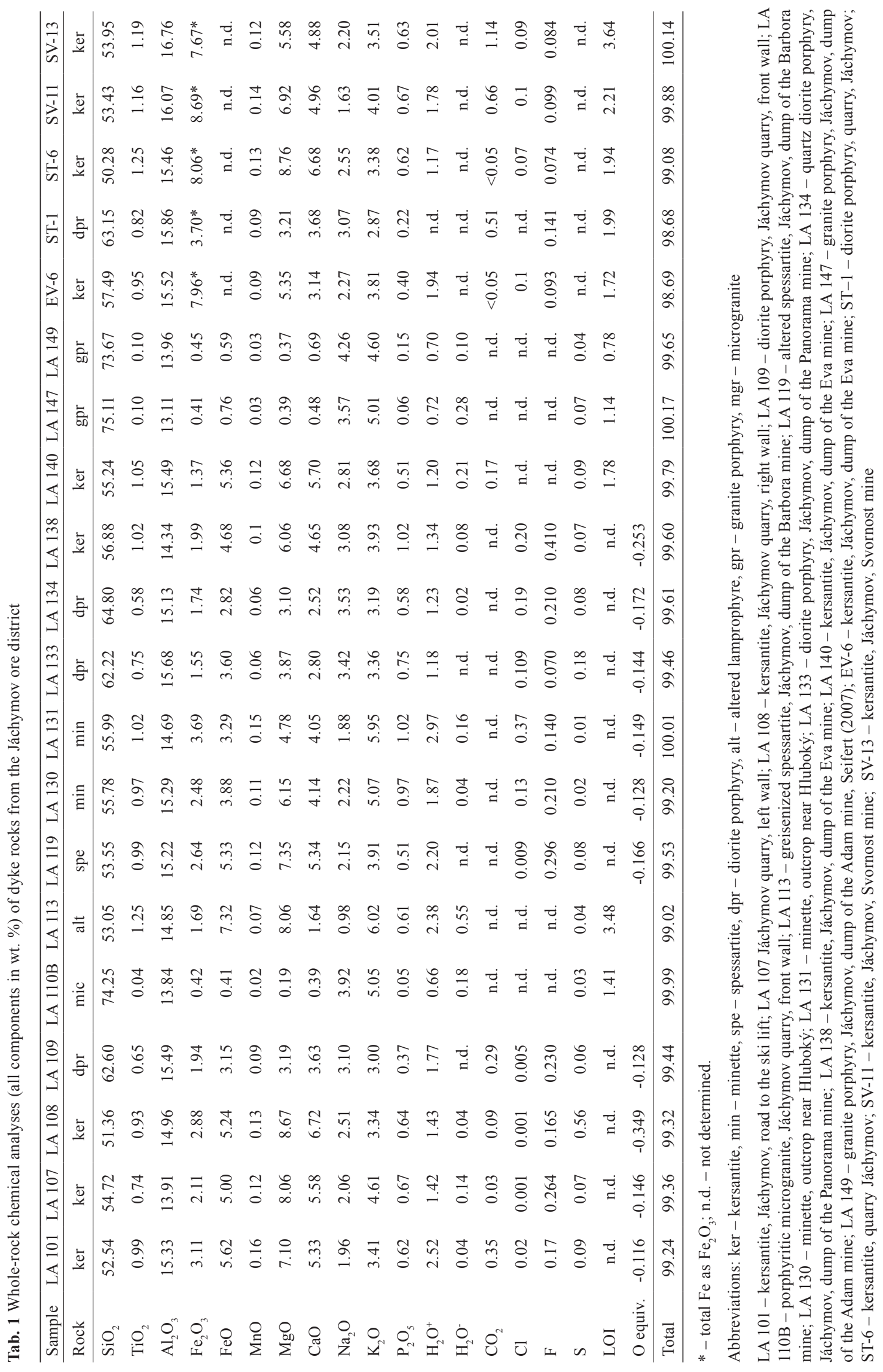




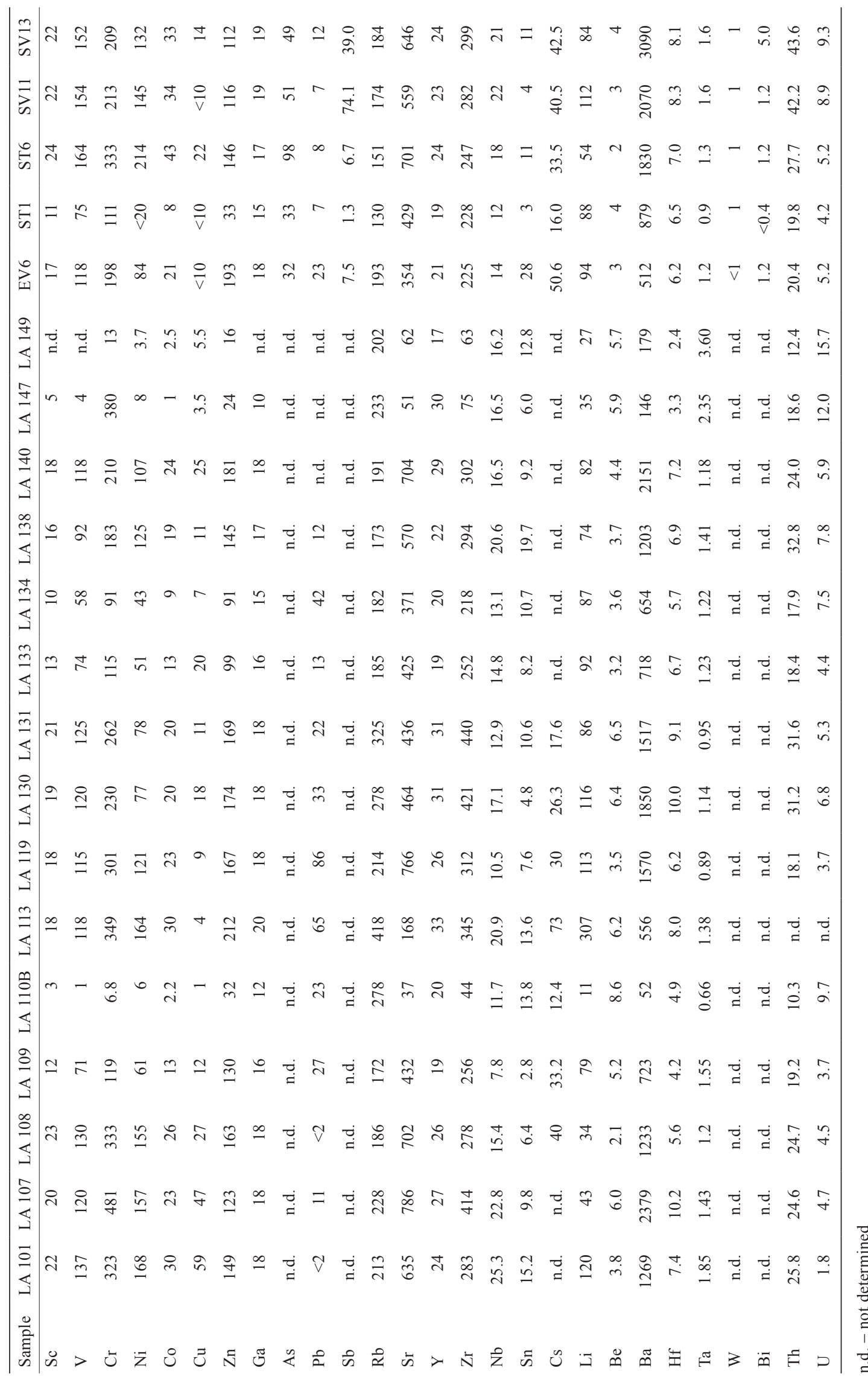




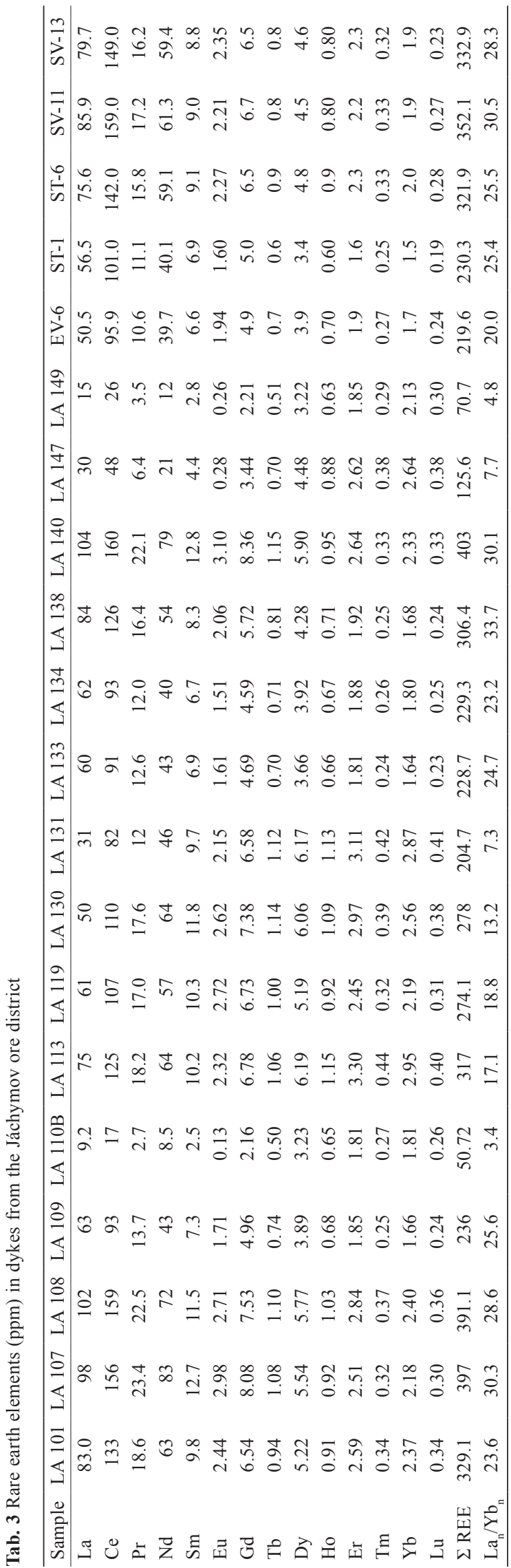

(Figs 12 and 13). Lamprophyres represent alkaline, shoshonitic magmas, whereas granite and diorite porphyries correspond to high-K calc-alkaline compositions (Fig. 13). Lamprophyres are of calc-alkaline type (CAL), which is frequently associated with granitoid intrusions (Rock 1991).

Kersantites and spessartites show decreasing $\mathrm{MgO}$ concentrations, from $8.8 \mathrm{wt}$ \% in melanocratic kersantites to $5.6 \mathrm{wt} \%$ in quartz-bearing kersantites. The elevated concentration of $\mathrm{MgO}$ in greisenized spessartite (8.06 wt. \% - sample LA 113) is matched by the enrichment in iron. Plagioclase decomposition during greisenization of spessartite appears to be responsible for depletion in calcium. Total alkalies range from 5.6 to $7.2 \mathrm{wt}$. \%, with the $\mathrm{K}_{2} \mathrm{O} / \mathrm{Na}_{2} \mathrm{O}$ ratios falling between 1.28 and 2.46. The highest contents of $\mathrm{K}_{2} \mathrm{O}$ are in minettes (5.95 wt. \%), while kersantites plot along a separate trend line positively correlated with silica. The $\mathrm{Na}_{2} \mathrm{O}$ concentrations show a remarkable scatter and depart from world calc-alkaline lamprophyre averages (Rock 1991). Relatively high alumina abundances place kersantites and spessartites close to the metaluminous-peraluminous boundary.

In contrast to other lamprophyres, minettes show higher total alkali contents (7.3 to $7.8 \mathrm{wt}$. \%) and have very high $\mathrm{K}_{2} \mathrm{O} / \mathrm{Na}_{2} \mathrm{O}$ ratios, scattering between 2.3 to 3.2 and $\mathrm{MgO}>3$ wt. $\%$. Hence they satisfy the classification criteria for ultrapotassic rocks defined by Foley et al. (1987). Greisenized spessartite from the Barbora mine (sample LA 113) has a very high $\mathrm{K}_{2} \mathrm{O} / \mathrm{Na}_{2} \mathrm{O}$ ratio (6.1), is remarkably depleted in $\mathrm{CaO}$, which imparts strongly peraluminous nature $(\mathrm{A} / \mathrm{CNK}=1.34)$. This extreme composition reflects intense replacement of primary mafic minerals by secondary dark micas.

Diorite-granodiorite porphyries display fairly narrow range of major-element compositions. In contrast to other dyke rocks, these porphyries have $\mathrm{K}_{2} \mathrm{O} \leq \mathrm{Na}_{2} \mathrm{O}$ $\left(\mathrm{K}_{2} \mathrm{O} / \mathrm{Na}_{2} \mathrm{O}=0.88-0.98\right)$. They are weakly peraluminous $(\mathrm{A} / \mathrm{CNK}=1.04-1.09)$. The $\mathrm{mg}$ values range from 53.7 to 63.2 and are relatively high for the rocks with the silica contents between 62 and 65 wt \%. Granite porphyries (and porphyritic microgranites) are $\mathrm{SiO}_{2}$-rich dykes with very low $\mathrm{TiO}_{2}$ concentrations ( 0.05 to $\left.0.10 \mathrm{wt} . \%\right)$ and mg-values (30.1 to 39.9$)$. Their weakly peraluminous nature $(\mathrm{A} / \mathrm{CNK}=1.05$ to 1.10$)$ is consistent with subordinate amounts of dark and white micas.

Most major elements show linear correlations with $\mathrm{SiO}_{2}$ from lamprophyres to diorite porphyries and granite porphyries, with well-defined gaps between the three rock groups. Concentrations of $\mathrm{TiO}_{2}, \mathrm{FeO}_{\text {tot }}, \mathrm{MgO}$, $\mathrm{CaO}$ and $\mathrm{P}_{2} \mathrm{O}_{5}$ decrease and those of $\mathrm{Na}_{2} \mathrm{O}$ increase with $\mathrm{SiO}_{2}$ linearly (Fig. 13). Such trends are compatible with cotectic crystallization of rock-forming silicates, oxides and phosphates, or suggest origin of diorite porphyries by magma mixing. It is noteworthy that the alumina concen- 


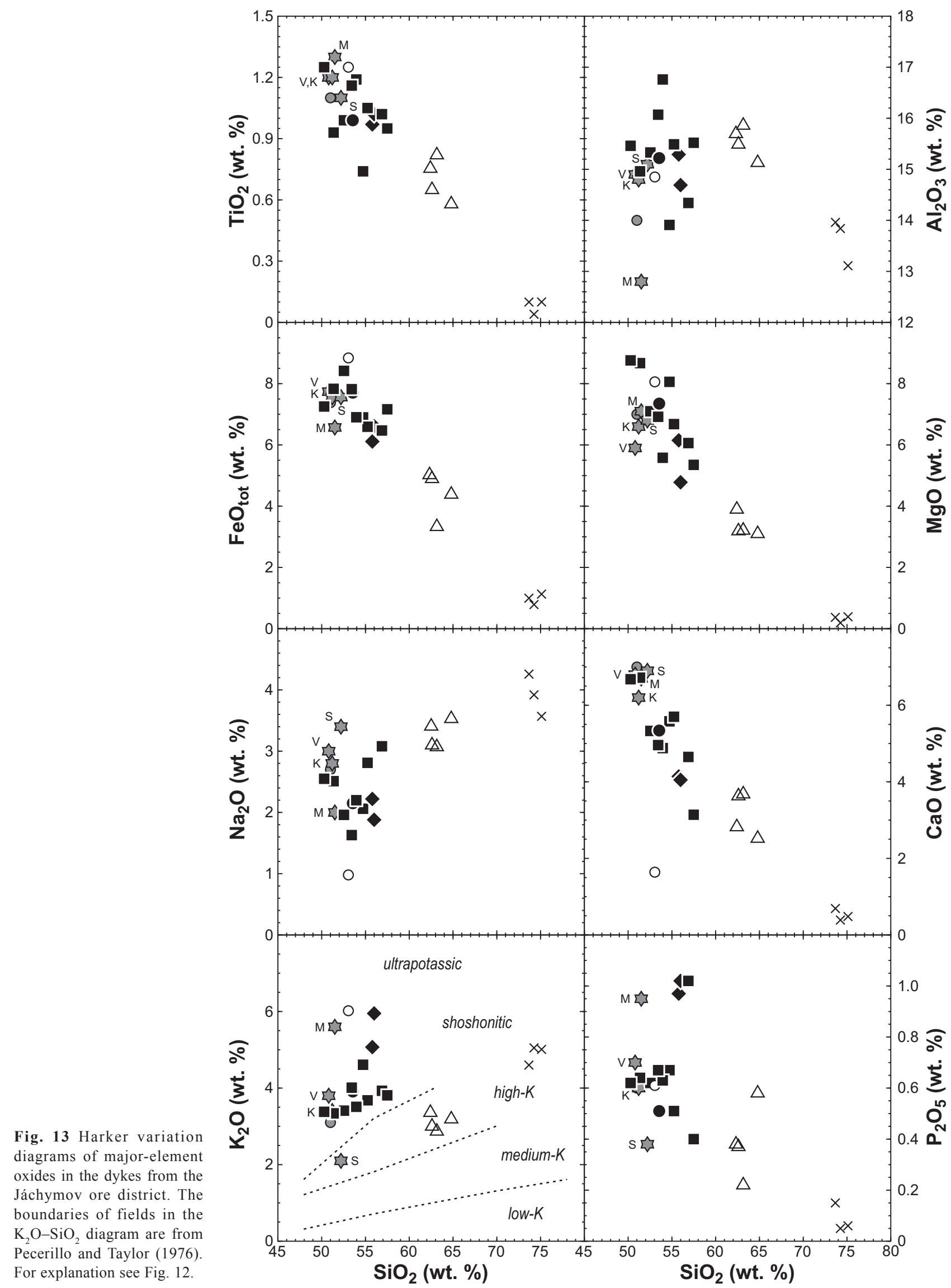


trations show a broad scatter in lamprophyres (13.9-16.7 wt. $\% \mathrm{Al}_{2} \mathrm{O}_{3}$ ) but remain elevated in diorite porphyries (15.1-15.9 wt. $\% \mathrm{Al}_{2} \mathrm{O}_{3}$ ). Abundances of $\mathrm{K}_{2} \mathrm{O}$ reach their maximum of 3.3-6.0 wt. \% in lamprophyres, in contrast with potassium depletion observed in diorite porphyries (2.9-3.4 wt. $\% \mathrm{~K}_{2} \mathrm{O}$ ).

\subsection{Volatile and trace elements}

Most of the trace elements preserve linear variations with $\mathrm{SiO}_{2}$ and mirror variations observed for major-element oxides. Compatible elements such as $\mathrm{Cr}, \mathrm{Ni}, \mathrm{V}, \mathrm{Zr}, \mathrm{Hf}$, $\mathrm{Sr}$ and $\mathrm{Ba}$ noticably decrease with increasing $\mathrm{SiO}_{2}$. In contrast, $\mathrm{Rb}$ and $\mathrm{U}$ display an incompatible increase towards granite porphyries. Abundances of $\mathrm{Nb}$ and $\mathrm{Ta}$ show moderate scatter. Behaviour of $\mathrm{Li}$ and $\mathrm{F}$ is controlled by modal contents of dark micas and concentrations of these elements decrease from lamprophyres (up to $120 \mathrm{ppm}$ $\mathrm{Li}, 0.06-0.4$ wt. \% F) towards granite porphyries (10-35 ppm Li, less than 0.06 wt. \% F).

Rubidium contents are increased in minettes and kersantites (150-220 ppm), being higher than are the average minette or kersantite compositions according to Rock (1991). Diorite porphyries have Rb concentrations, which overlap with the lower part of the interval for $\mathrm{Rb}$ contents in some kersantites. However granite porphyries have increased $\mathrm{Rb}$, similar to that of Rb-rich lamprophyres. The greisenized spessartite has Rb of $418 \mathrm{ppm}$ (not indicated in Fig. 14). Barium contents dispersed in a broad interval of 500 to $2500 \mathrm{ppm}$ show a trend line separated from diorite porphyries in correlation with silica. Diorite porphyries differ from lamprophyres by constantly lower values of $\mathrm{Ba}$ and $\mathrm{Sr}$ (Fig. 14).

The variation diagrams of the transition elements $(\mathrm{V}$, $\mathrm{Cr}$ and $\mathrm{Ni}$ ) show negative correlation with silica (Fig. 14). Vanadium contents range from 100 to $190 \mathrm{ppm}$ and their highest values correspond to the average of calkalkaline lamprophyres suggested by Rock (1991). The Cr spans the contents between 200 to $400 \mathrm{ppm}$ in kersantites with a single outlier reaching $460 \mathrm{ppm}$ in the kersantite from the Jáchymov quarry. These values are distinctly lower than those reported for the world kersantites. The $\mathrm{Cr}$ contents in minettes are lower and correspond to some lower ranges of $\mathrm{Cr}$ contents in kersantites. Diorite porphyries are significantly impoverished in $\mathrm{Cr}(\sim 100$ $\mathrm{ppm})$. The covariations of some major-element oxides with selected trace elements and among selected trace elements themselves are shown in Fig. 15. The variation between $\mathrm{Zr}$ and $\mathrm{Y}$ contents shows a linear correlation. On the contrary, a large scatter in the $\mathrm{TiO}_{2}$ vs. $\mathrm{Zr}$ diagram shows that part of $\mathrm{Zr}$ is possibly associated with titanite as documented by Seifert and Kramer (2003) for the Erzgebirge lamprophyres.
The $\mathrm{K}_{2} \mathrm{O}$ is positively correlated with $\mathrm{Rb}$ as it follows from association of $\mathrm{Rb}$ with $\mathrm{K}$ in dark micas of kersantites and spessartites. The variation between $\mathrm{La}$ and $\mathrm{P}_{2} \mathrm{O}_{5}$ that would suggest a dependence on accessory apatite is not clearly indicated. Tin is correlated neither with $\mathrm{Li}$ nor $\mathrm{F}$ and this lack of relationship stresses a common irregular distribution of cassiterite as the main carrier of tin in greisenized rocks.

The variation diagrams for the HFSE are shown in Fig. 16. In lamprophyres, $\mathrm{Zr}$ contents are always increased and vary from 200 to $450 \mathrm{ppm}$, whereas in granite porphyries they are well below $100 \mathrm{ppm}$. The $\mathrm{Zr}$ contents in minettes are distinctly higher compared to other lamprophyres. Diorite porphyries have lower $\mathrm{Zr}$ than most lamprophyres. Niobium contents are scattered in all the rock types and they are increased in most lamprophyres compared with diorite porphyries (Fig. 16). The ranges of Ta contents are similar for lamprophyres and diorite porphyries.

Uranium contents are markedly increased in some granite porphyries but in lamprophyres and diorites they are below $10 \mathrm{ppm}$ in all cases (Tabs 4 and 5, Fig. 16). The low $\mathrm{U}$ contents in mafic dykes are unexpected in view of the fact that the dykes occur within the U-mineralized district jointly with uranium-bearing ore veins. Thorium concentrations in all lamprophyres are higher than in diorite porphyries (Tab. 5). This element is also enriched compared with the global calc-alkaline lamprophyre averages according to Rock (1991). The contents of U (Ra) (Fig. 17) in diorite porphyries (20.1 ppm and $4.8 \mathrm{ppm}$, respectively) are slightly lower than in lamprophyres but they are the only group of mafic dyke rocks having $\mathrm{U}$ and $\mathrm{U}(\mathrm{Ra})$ contents nearly in equilibrium (Tabs 4 and 5), while $\mathrm{Ra}$ and $\mathrm{U}$ are in disequilibrium $(\mathrm{U}(\mathrm{Ra})>\mathrm{U})$ in all lamprophyres. The $\mathrm{U}$ and $\mathrm{Th}$ concentrations are strongly positively correlated in mafic dykes (Fig. 17). Granite porphyries have higher U contents (Tab. 5) compared with mafic rocks and do not follow identical or similar trend lines (Fig. 17). The radioactivity in silicic dyke rocks is mainly caused by $\mathrm{U}$ with the $\mathrm{Th} / \mathrm{U}$ ratio about 1 , and they contain, in contrast with lamprophyres, Ra nearly in equilibrium with $\mathrm{U}$.

The diagram $\mathrm{Zr}$ vs. Hf (Fig. 17) shows a scatter of values, which indicates possibly several $\mathrm{Zr}$ sources rather than accessory zircon as the only sink of $\mathrm{Zr}$ and Hf. The significant $\mathrm{Nb} v s$. Ta correlation proves more likely the dependence of $\mathrm{Nb}$ and $\mathrm{Ta}$ on a single mineral (possibly of the columbite-tantalite group).

The chondrite-normalized REE patterns (Fig. 18a) of lamprophyres show characteristic predominance of the LREE over HREE, which is typical of the low degree of partial melting of a mantle source (Rollinson 2003) and accords with Bachinski and Scott (1979) and Rock 


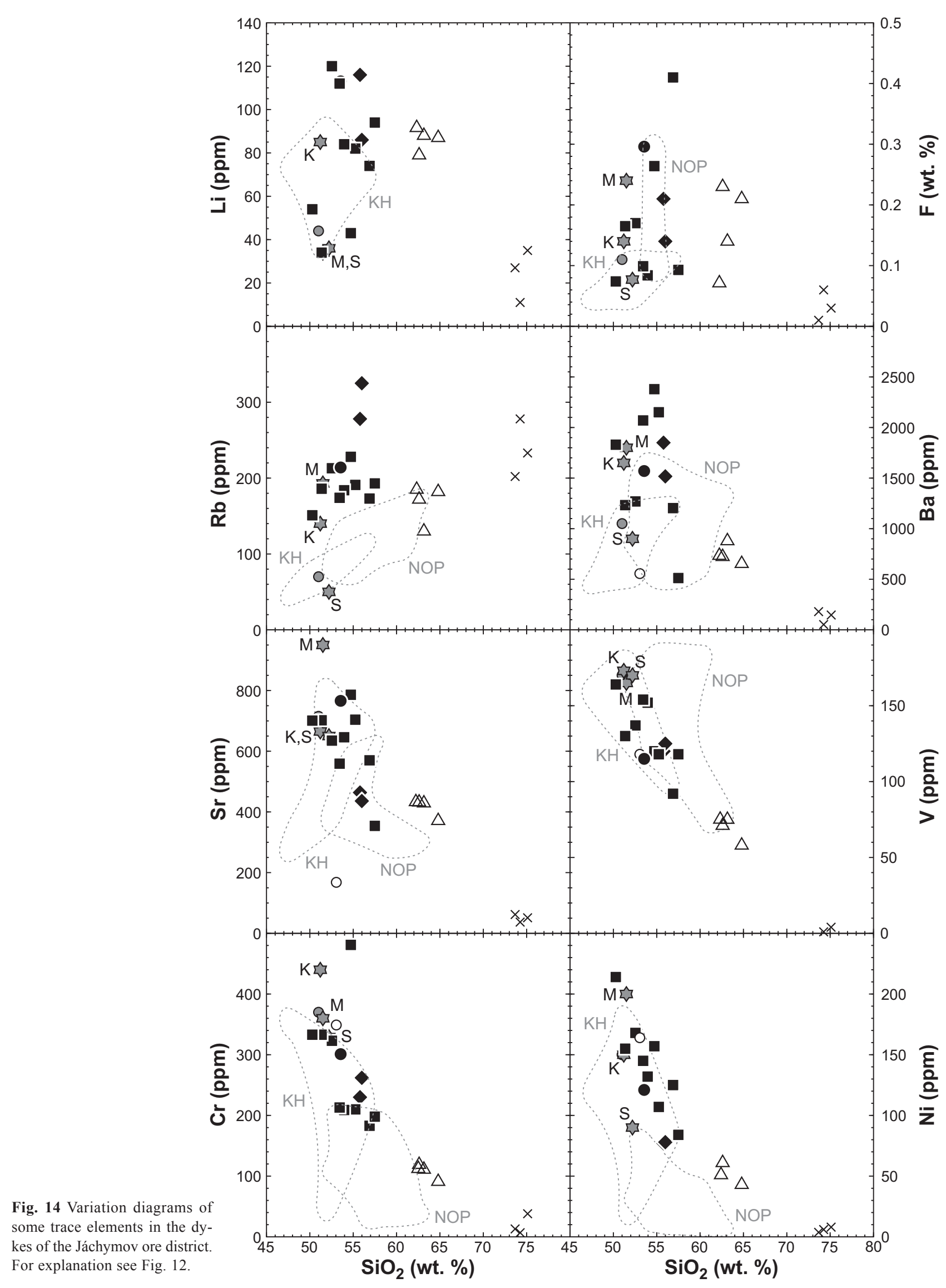



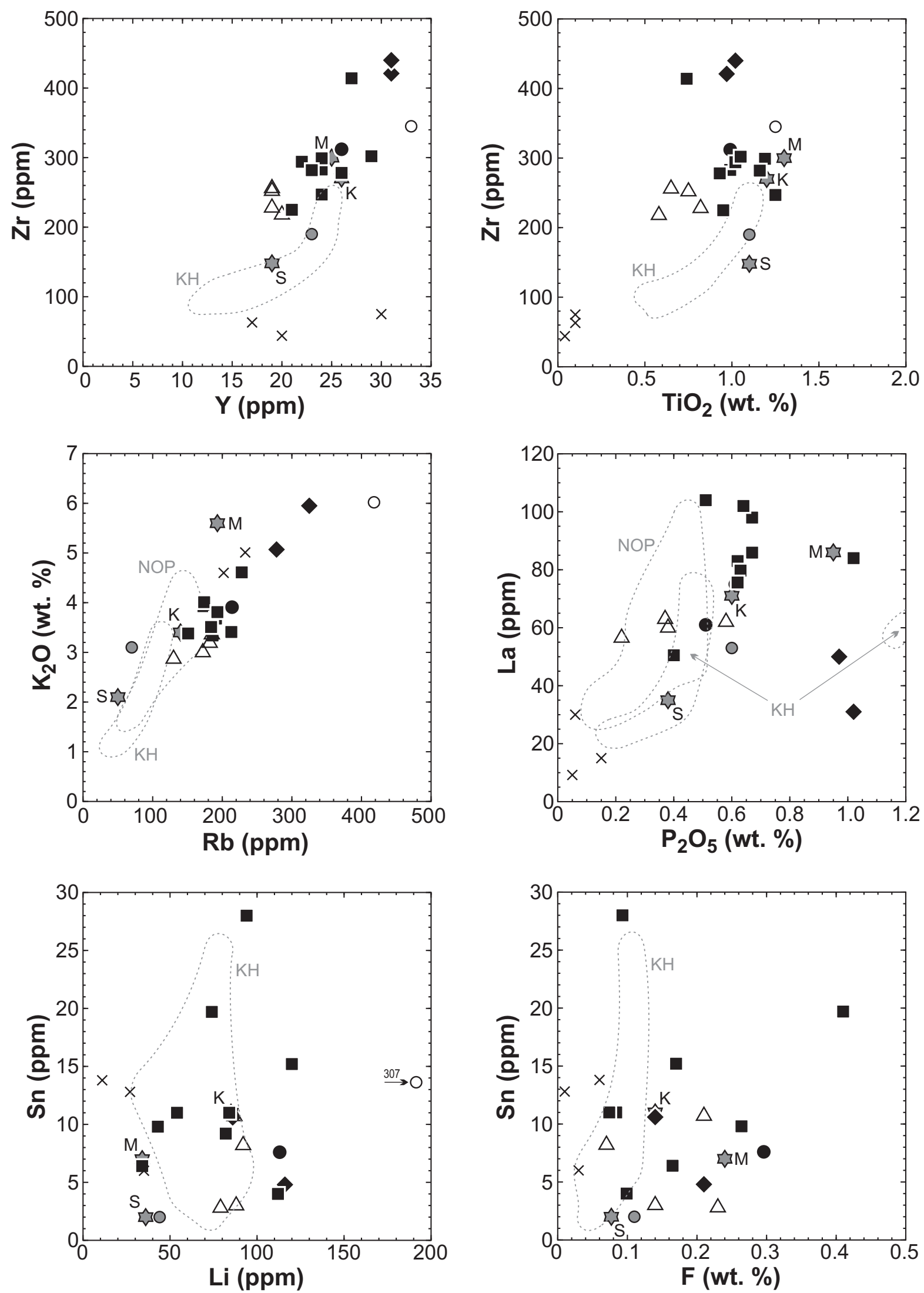

Fig. 15 The covariations of some major-element oxides with selected trace elements in the dykes of the Jáchymov ore district. For explanation see Fig. 12 


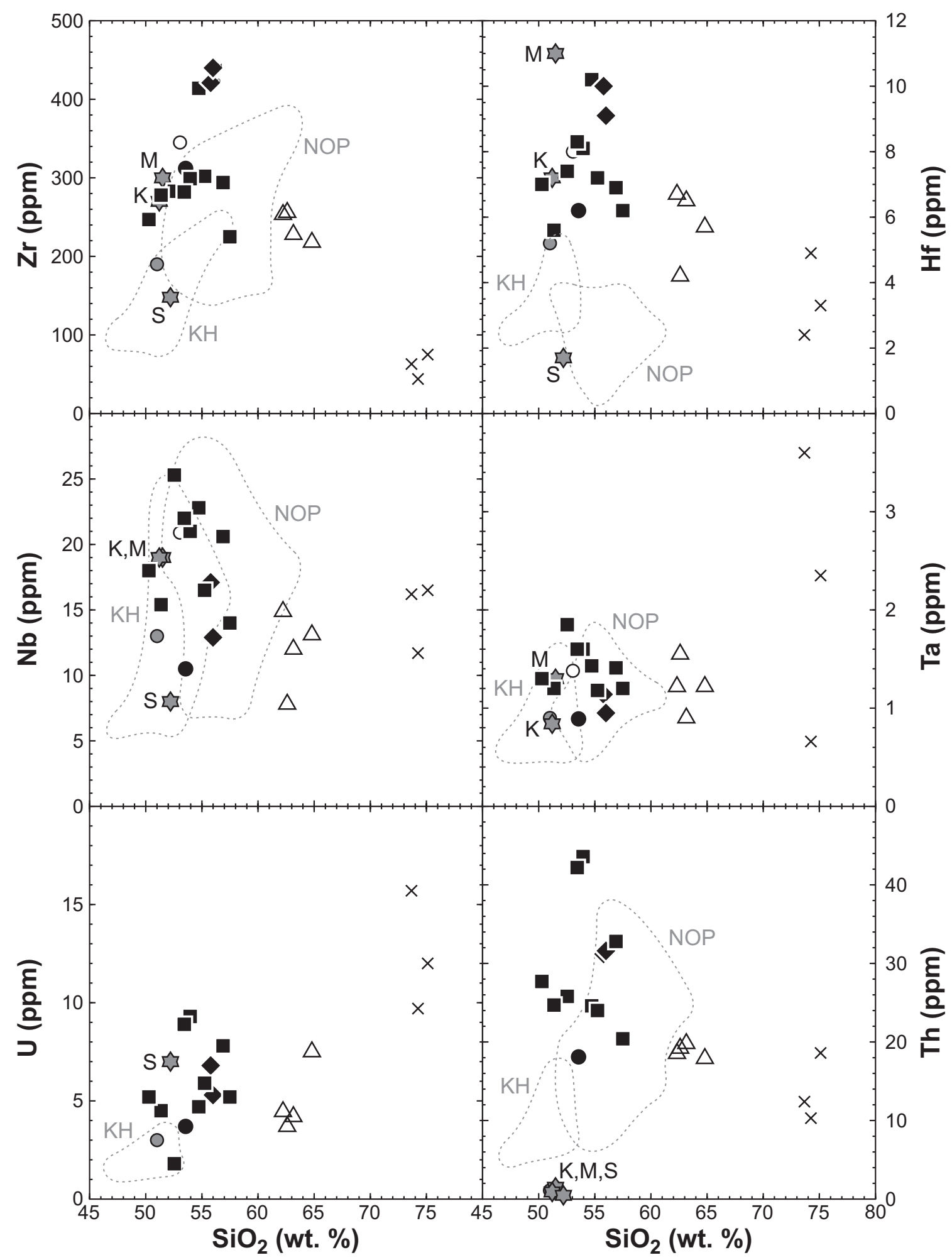

Fig. 16 Variation diagrams of the HFSE in the dykes in the Jáchymov ore district. For explanation see Fig. 12.

(1991). It is characterized by the absence of negative Eu anomaly suggesting the lack of feldspar fractionation from the melt. The course of normalized patterns for kersantites, minettes and spessartite are virtually identical.
The altered spessartite has the same pattern as unaltered rock. The dykes of diorite porphyries (Fig. 18b) are also indistinguishable from lamprophyres by the shape of their REE pattern and have approximately the same 
Tab. 4 Contents of radioactive elements (ppm and wt. \%) in dykes of the Jáchymov ore district

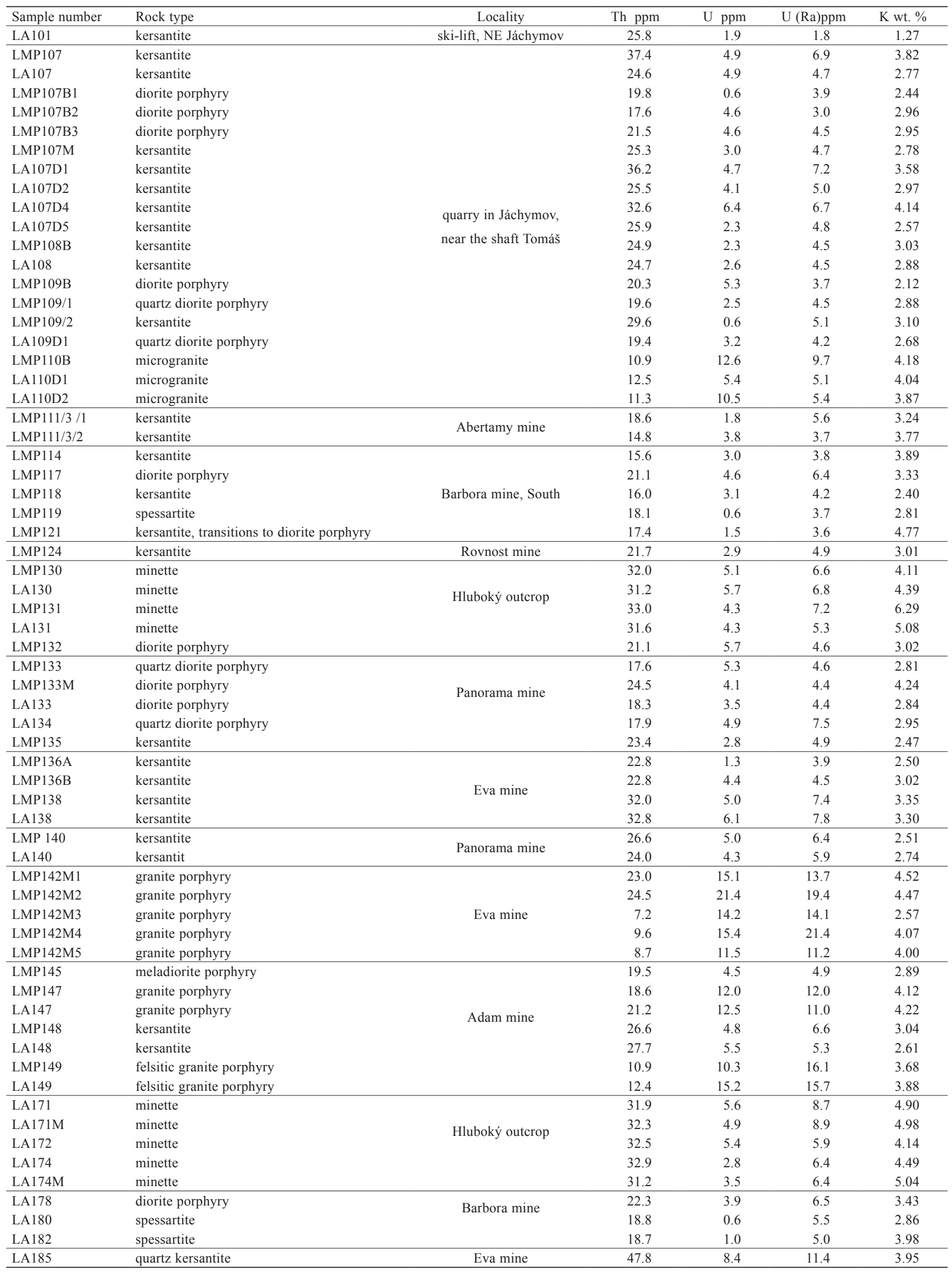



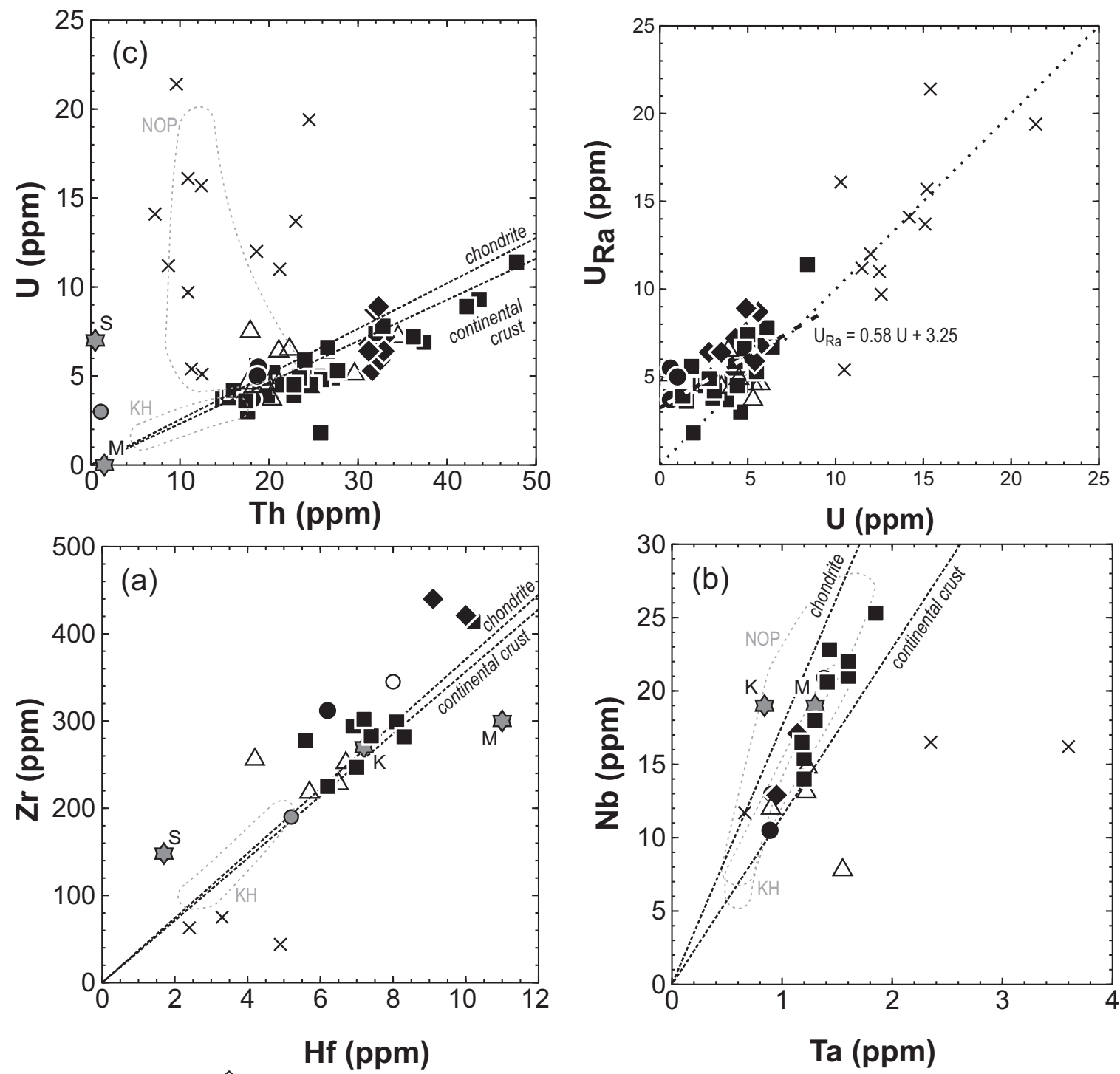

Fig. 17 Variation diagrams of some HFS elements normalized to chondrite and to the average composition of the continental crust (McDonough and Sun 1995; Rudnick and Gao 2003). The U(Ra)/U plot shows the degree of radiogenic equilibrium (see Appendix 1). For explanation see Fig.12.

Tab. 5 Statistical parameters for distribution of the radioactive elements in dykes of the Jáchymov ore district

\begin{tabular}{lcrrrr}
\hline Dyke rocks & Statistical parameter & Th ppm & U ppm & U(Ra) ppm & K wt. \% \\
\hline granite porphyries & ME & 11.85 & 12.55 & 12.85 & 4.06 \\
$(\mathrm{n}=12)$ & $\mathrm{AM}$ & 14.23 & 13.01 & 12.90 & 3.97 \\
& $\mathrm{SD}$ & 5.69 & 3.67 & 4.74 & 0.48 \\
\hline \multirow{2}{*}{ diorite porphyries } & $\mathrm{ME}$ & 19.80 & 4.60 & 4.50 & 2.95 \\
$(\mathrm{n}=16)$ & $\mathrm{AM}$ & 20.12 & 4.06 & 4.78 & 2.97 \\
& $\mathrm{SD}$ & 1.98 & 1.33 & 1.21 & 0.49 \\
\hline \multirow{2}{*}{ kersantites } & $\mathrm{ME}$ & 25.50 & 3.95 & 5.05 & 3.03 \\
$(\mathrm{n}=25)$ & $\mathrm{AM}$ & 26.14 & 3.86 & 5.43 & 3.10 \\
& $\mathrm{SD}$ & 7.39 & 1.79 & 1.83 & 0.70 \\
\hline spessartites & $\mathrm{ME}$ & 18.70 & 0.60 & 5.00 & 2.86 \\
$(\mathrm{n}=3)$ & $\mathrm{AM}$ & 18.53 & 0.73 & 4.73 & 3.22 \\
\hline \multirow{2}{*}{ minettes } & $\mathrm{ME}$ & 3.20 & 4.90 & 6.60 & 4.90 \\
$(\mathrm{n}=9)$ & $\mathrm{AM}$ & 32.07 & 4.62 & 6.91 & 4.82 \\
& $\mathrm{SD}$ & 0.63 & 0.93 & 1.13 & 0.63 \\
\hline
\end{tabular}

ME - median; AM - arithmetic mean; SD - standard deviation 


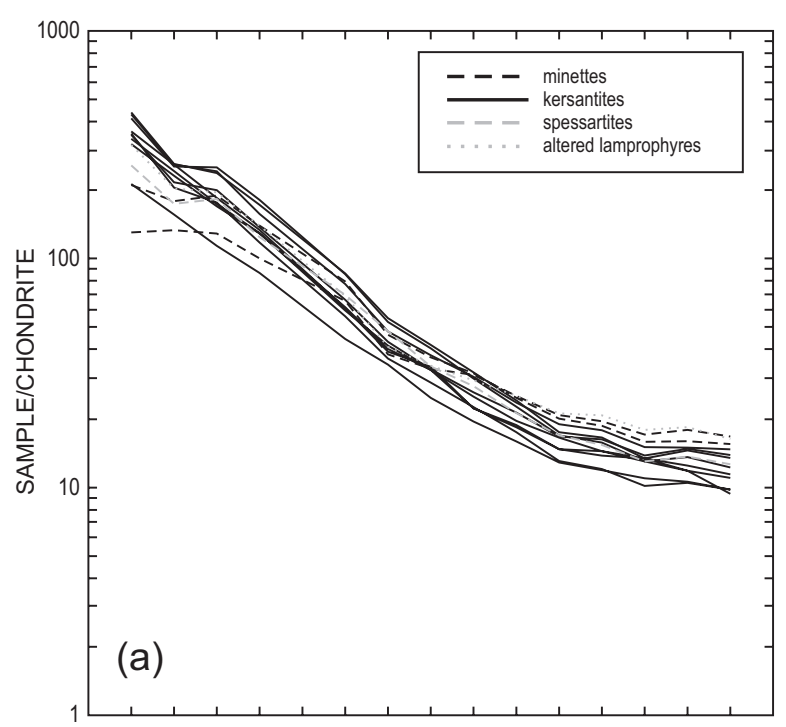

La Ce Pr Nd Pm Sm Eu Gd Tb Dy Ho Er Tm Yb Lu

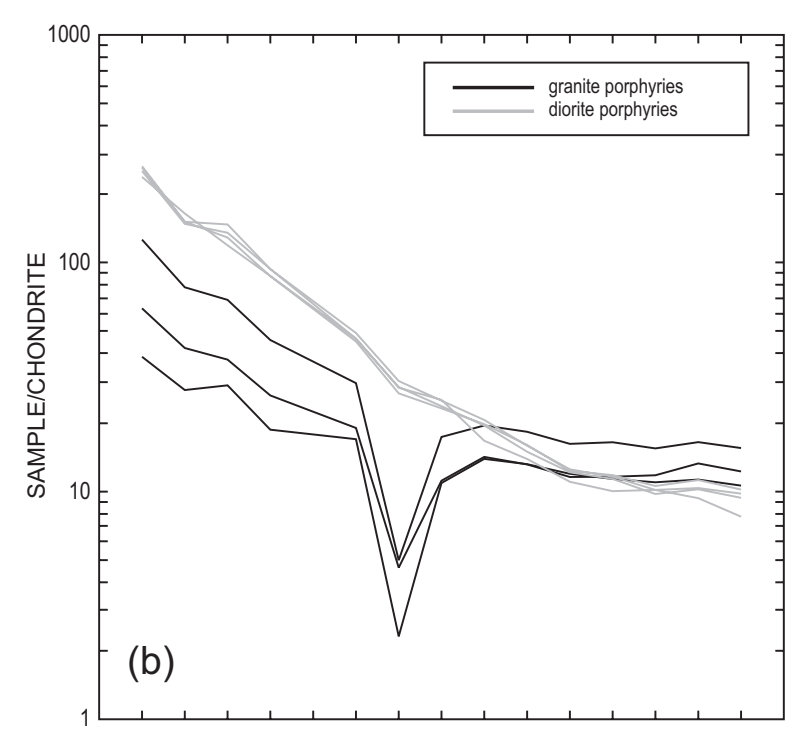

La Ce Pr Nd Pm Sm Eu Gd Tb Dy Ho Er Tm Yb Lu

Fig. 18 Chondrite-normalized REE patterns of lamprophyres (a) and porphyries (b) from the Jáchymov ore district (normalization values according to Sun and McDonough 1989).

amount of REE. Granite porphyries are characterized by lower contents of REE and a typical negative $\mathrm{Eu}$ anomaly.

\subsection{Spiderdiagrams}

Multielement variation diagrams (Fig. 19a) for lamprophyres normalized to primitive mantle (Sun and Donough
1989) show enrichment in Th, slight relative depletion in $\mathrm{Rb}$ and $\mathrm{Ba}$, as well as a strong depletion in $\mathrm{Sr}$ and HFSE. Significant troughs exist for $\mathrm{U}, \mathrm{Nb}$ and $\mathrm{Ta}$ and a very pronounced one for Ti. Spiderdiagrams for granite porphyries (Fig. 19b) have a more variegated course with the troughs for $\mathrm{Ba}, \mathrm{Nb}, \mathrm{Li}, \mathrm{La}, \mathrm{Sr}, \mathrm{Eu}$ and Ti. Diorite porphyries show patterns resembling more lamprophyres than granite porphyries for the most of mobile elements.
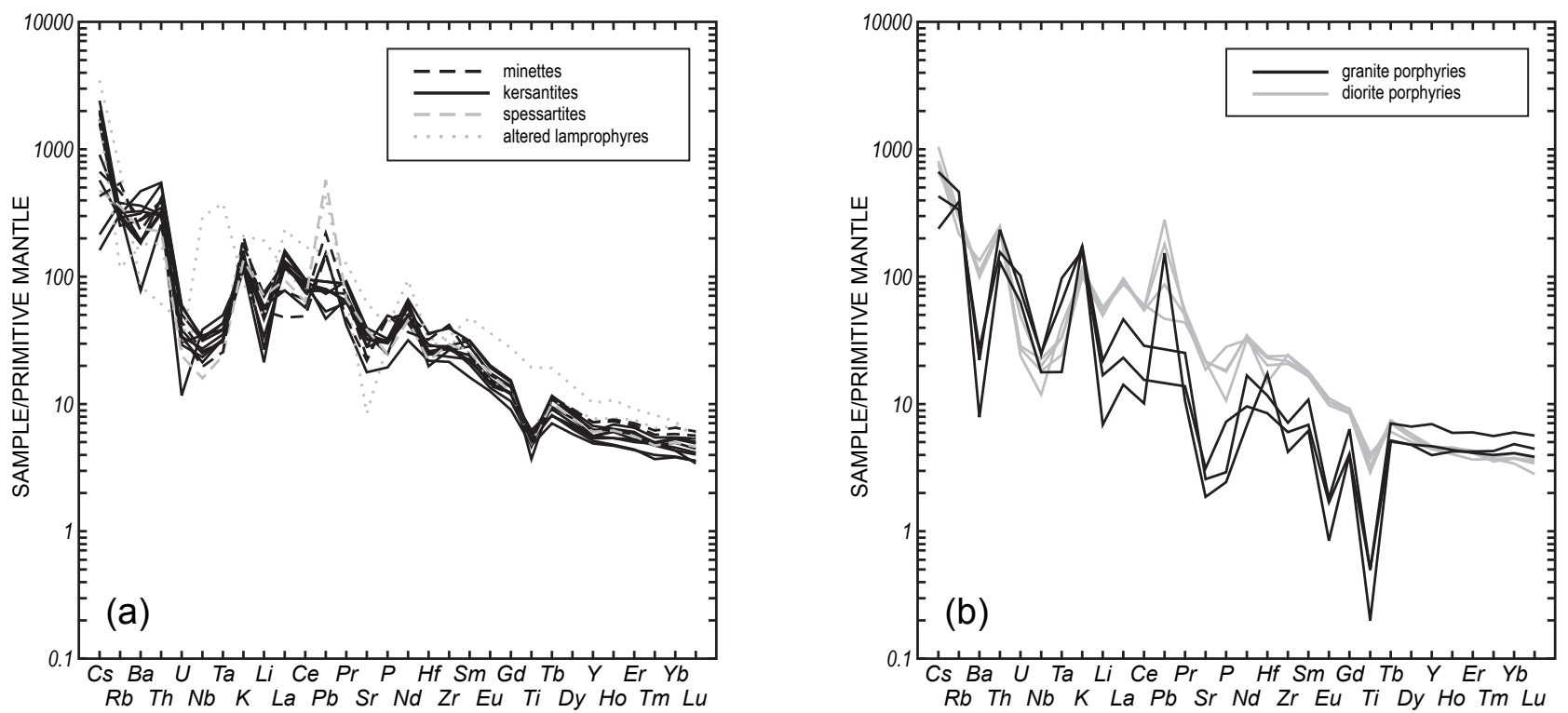

Fig. 19 Primitive mantle-normalized extended multielement plot (spider diagram). Normalizing values according to Sun and McDonough (1989). 


\section{Stable isotopes}

\subsection{Oxygen isotope composition of dyke rocks}

Oxygen isotope compositions summarised in Tab. 6 are highly variable, ranging from $\delta^{18} \mathrm{O}$ of $1.4 \%$ in the minette from Hluboký up to $7.8 \%$ SMOW in the kersantite from the Jáchymov quarry. The $\delta^{18} \mathrm{O}$ distribution is apparently not dependent on the contents of $\mathrm{SiO}_{2}$ or $\mathrm{MgO}$. The compositions of the studied kersantites and diorite porphyries fall into the interval reported in the literature for gabbros and basalts $\left(\delta^{18} \mathrm{O}=5.5\right.$ to $7.5 \%$ SMOW, Faure 1986). The oxygen of the minettes is relatively light $\left(\delta^{18} \mathrm{O}=1.4-2.0 \% \mathrm{SMOW}\right)$. This is different from the data of Kramer (1976) from the Erzgebirge (8.2 and $6.3 \%$ respectively), and the compositions of spessartites and kersantites ranging from 3.1 to $9.3 \%$. The low $\delta^{18} \mathrm{O}$ values for some Erzgebirge lamprophyres were explained by isotopic exchange of the rocks with hydrothermal solutions active after the crystallization of silicates (Kramer 1976). This has been manifested in the present study also in silicic dyke rocks from the Jáchymov district, where the $\delta^{18} \mathrm{O}$ values reached $3.9 \%$ SMOW in the phenocrystpoor granite porphyry (microgranite) and $4.7 \%$ SMOW in the granite porphyry rich in phenocrysts respectively.

\subsection{Oxygen and carbon isotopes in carbona- tes from mafic dykes}

Isotopic compositions of $\mathrm{C}$ and $\mathrm{O}$ in carbonates from the dykes in Jáchymov district and from hydrothermal ore veins are given in Tab. 7 and shown in Fig. 20. For comparison we used isotopes data for $\mathrm{C}$ and $\mathrm{O}$ in nine samples of carbonates from the arsenide and sulphoarsenide stages of mineralization (Ondruš et al. 2003). In diagram $\delta^{13} \mathrm{C} v s . \delta^{18} \mathrm{O}$ the data points for carbonates in studied mafic dykes plot outside the fields of primary magmatic carbonates. High values of $\delta^{18} \mathrm{O}$ in the studied carbonates testify to their origin at the hydrothermal stage as the $\mathrm{C}-\mathrm{O}$ isotopic compositions of mafic dykes and hydrothermal carbonates practically coincide with each other. The only exception is a single, anomalously high $\delta^{13} \mathrm{C}$ value for dolomite (2.1\%o PDB) belonging to the arsenic-sulphide stage of deposition. This might have been caused by mobilization of carbonates from intercalations of calc-silicate rocks common in the Jáchymov crystalline rocks.

The stable isotopic compositions determined in carbonates in mafic dykes are in accord with microscopic observations and suggest that carbonates are hydrothermal minerals related to the deposition of carbonates in the vein fillings and to the wall rock alterations. Thus, they are not primary magmatic carbonates as shown by Fig. 20. The isotopic composition of carbon in carbonates falls within a narrow limit of -5.7 to $-9.0 \% \delta^{13} \mathrm{C}$ (PDB), which in hydrothermal systems (in equilibrium with calcite and graphite) depends on $\mathrm{pH}$ and $f \mathrm{O}_{2}$ of parental solutions (Faure 1986).

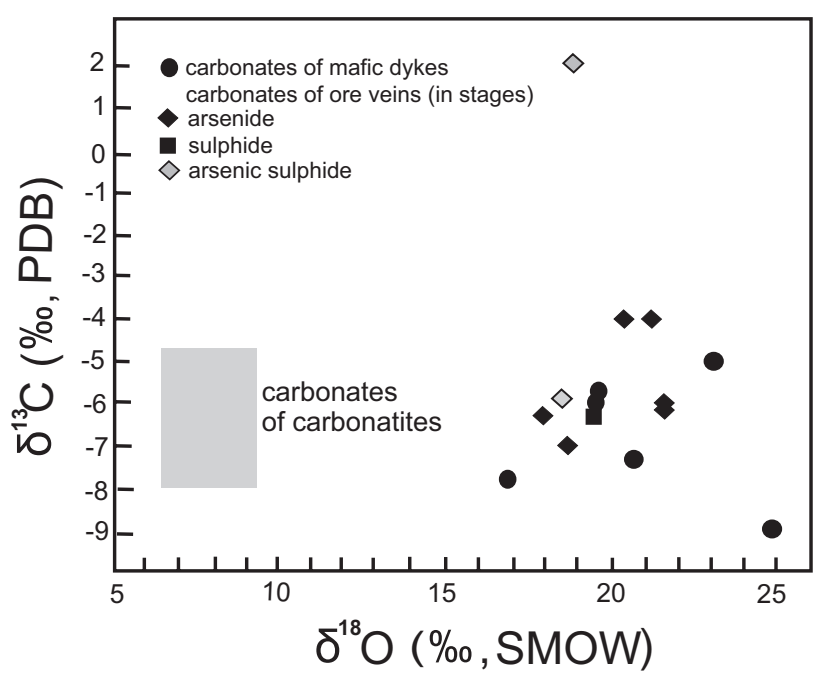

Fig. 20 Binary plot $\delta^{13} \mathrm{C}$ versus $\delta^{18} \mathrm{O}$ for the carbonates in mafic dykes and ore veins of the Jáchymov ore district (data from Žák et al. 2001; Ondruš et al. 2003).

Tab. 6 The contents of $\delta^{18} \mathrm{O}$ in dykes from the Jáchymov ore district

\begin{tabular}{|c|c|c|c|c|}
\hline Sample number & Rock type & Locality & $\delta^{18} \mathrm{O} \%$ SMOW & $* \delta^{18} \mathrm{O} \%$ SMOW \\
\hline LA 107 & kersantite & quarry, W side & 6.6 & 6.5 \\
\hline LA 108 & kersantite & quarry, $\mathrm{E}$ side & 7.8 & \\
\hline LA 109 & diorite porphyry & quarry, middle & 1.6 & 0.9 \\
\hline LA $110 \mathrm{~b}$ & microgranite & quarry,middle & 3.9 & \\
\hline LA 119 & spessartite & Barbora mine & 2.7 & \\
\hline LA 130 & minette & Hluboký outcrop & 2.0 & \\
\hline LA 133 & quartz diorite porphyry & Panorama mine & 6.2 & 6.2 \\
\hline LA 149 & granite porphyry & Adam mine & 4.7 & . \\
\hline
\end{tabular}

* - duplicate analyses 
Tab. 7 Isotopic composition of S in sulphides, and of $\mathrm{C}$ with $\mathrm{O}$ in carbonates of dykes from the Jáchymov ore district

\begin{tabular}{|c|c|c|c|c|c|c|c|c|c|}
\hline $\begin{array}{l}\text { Sample } \\
\text { number }\end{array}$ & $\begin{array}{l}\text { Petrographic } \\
\text { name }\end{array}$ & Locality & $\begin{array}{c}\mathrm{CO}_{2} \\
\%\end{array}$ & $\begin{array}{c}\mathrm{C}_{\text {carb }} \\
\%\end{array}$ & $\begin{array}{c}\mathrm{C}_{\text {tot }} \\
\%\end{array}$ & $\begin{array}{c}\mathrm{S}_{\text {tot }} \\
\%\end{array}$ & $\begin{array}{c}\delta^{13} \mathrm{C}_{\text {carb }} \\
\% \text {, PDB }\end{array}$ & $\begin{array}{c}\delta^{18} \mathrm{O}_{\text {carb }} \\
\% \text {, SMOW }\end{array}$ & $\begin{array}{l}\delta^{34} \mathrm{~S}_{\text {sulphide }} \\
\% \text {, CDT }\end{array}$ \\
\hline LA 108 & kersantite & quarry near the & 0.02 & 0.005 & 0.02 & 0.586 & n.d. & n.d. & 6.6 \\
\hline LA 109 & $\begin{array}{l}\text { quartz diorite } \\
\text { porphyry }\end{array}$ & shaft Tomáš & 0.41 & 0.112 & 0.14 & 0.027 & -5.7 & 19.6 & 3.2 \\
\hline LA 130 & minette & Hluboký & 0.03 & 0.008 & 0.03 & $<0.005$ & n.d. & n.d. & n.d. \\
\hline LA 134 & $\begin{array}{l}\text { quartz diorite } \\
\text { porphyry }\end{array}$ & Panorama & 0.26 & 0.071 & 0.08 & 0.089 & -7.3 & 20.6 & 2.0 \\
\hline LA 140 & kersantite & Eva & 0.09 & 0.025 & 0.05 & 0.087 & -9.0 & 25.0 & 0.5 \\
\hline
\end{tabular}

n.d. - not determined (due to small amount of carbonates)

\subsection{Sulphur isotopic composition of mafic dykes}

From comparison of the analyzed total sulphur and sulphidic sulphur it appears that that most sulphur in mafic dyke rocks is in the form of sulphides (Tab. 7). High amount of sulphidic sulphur in the samples of kersantite from the Jáchymov quarry (5860 $\mathrm{ppm})$ corresponds to arsenopyrite (löllingite) having $\delta^{34} \mathrm{~S}$ of $+6.6 \%$ CDT. This indicates that the sample has been contaminated by sulphur of crustal origin. The data from Žák et al. (2001) suggest that the crystalline rocks of the Krušné hory region are a sulphur reservoir with weakly positive values $\left(\delta^{34} \mathrm{~S} \sim+5.5 \%\right)$. The samples of mafic dykes have low $\mathrm{S}$ contents $(70-890 \mathrm{ppm})$ and their $\delta^{34} \mathrm{~S}$ values $(2.0$ to $6.6 \%$ CDT ) are only slightly higher than the mantle values (Faure 1986). Sulphur could have been carried by mafic rocks from a infracrustal source, even though it could have been partly affected by an admixture of crustal sulphur or fractionation of $\mathrm{H}_{2} \mathrm{~S}$ during the ascent. According to Šmejkal et al. (1974) the $\delta^{34} \mathrm{~S}$ values from the Krušné hory region range from -21 to $+17 \%$ CDT. This broad interval of values has been interpreted by Ondruš et al. (2003) as being caused by the switch in the source of sulphur in hydrothermal solutions and/or (more probably) by the changes in the crystallization conditions of sulphides.

\section{Petrophysical characteristics}

\subsection{Grain density}

The results of the measurements of petrophysical parameters are given in Tab. 8 and their statistical analysis in Tab. 9. Kersantites have been differentiated on the basis of magnetic data and the textures of the samples. The mean of grain density $(\mathrm{Dg})$ for all the groups of kersantites is practically identical. The means of grain densities for minettes and diorite porphyries are smaller than for kersantites and spessartites, mainly due to a higher content of feldspars in the former two. Grain densities of lamprophyres decrease due to alterations transforming very dense minerals like olivine and pyroxene to less dense amphibole, biotite, and chlorite. The measured values of Dg decrease in the order spessartites $\rightarrow$ common kersantites $\rightarrow$ kersantites with ophitic texture $\rightarrow$ minettes + normal diorite porphyries $\rightarrow$ magnetic diorite porphyries. The sample of quartz kersantite LA185 is an exception among kersantites as its relatively low Dg value $\left(2.728{\mathrm{~g} . \mathrm{cm}^{-3}}^{-3}\right)$ is close to those for diorite porphyries (Tab. 8). The granite porphyries have the lowest values of the measured silicic rocks from the Karlovy Vary region (Hrouda and Chlupáčová 1993).

\subsection{Magnetic properties}

Magnetic susceptibility values $\mathrm{Km}$, parameters characterising the anisotropy (degree of anisotropy - P, shape factor of anisotropy of magnetic fabric $-\mathrm{T}$ ) and values of natural remanent magnetization (NRM) are summarised in Tab. 8. Most lamprophyres and diorite porphyries have relatively low magnetic susceptibility in the order of $10^{-4}$ [SI]. Granite porphyries exhibit even lower values in the order of $10^{-5}[\mathrm{SI}]$ as expected from their mineralogical composition.

The data correspond well with high amounts (up to 50 vol. \%) of paramagnetic mafic minerals such as biotite and amphibole (Nagata 1961). Low amounts of other paramagnetic minerals (e.g., titanite, ilmenite and pyrite) do not influence the $\mathrm{Km}$ values. Increased $\mathrm{Km}$ values 
Tab. 8 Petrophysical parameters of dykes in the Jáchymov ore district

\begin{tabular}{|c|c|c|c|c|c|c|c|c|}
\hline Sample & Rock type & $\begin{array}{l}\mathrm{Dg} \\
\mathrm{g} / \mathrm{cm}^{3}\end{array}$ & $\begin{array}{c}\text { Por } \\
\text { vol. } \%\end{array}$ & $\begin{array}{c}\mathrm{Km} \\
10^{-6} \mathrm{SI}\end{array}$ & $\mathrm{P}$ & $\mathrm{T}$ & $\begin{array}{c}\text { NRM } \\
\text { nT }\end{array}$ & $\begin{array}{l}\text { Magnetic mineral } \\
\text { (notes) }\end{array}$ \\
\hline LA107A & kersantite & 2.869 & 1.10 & $\begin{array}{r}657 \\
1944\end{array}$ & $\begin{array}{l}1.048 \\
1.113\end{array}$ & $\begin{array}{r}0.560 \\
-0.067\end{array}$ & $\begin{array}{r}40.1 \\
373.3\end{array}$ & pyrrhotite* \\
\hline LMP107B1 & diorite porphyry & 2.734 & 2.00 & $\begin{array}{l}3885 \\
3427\end{array}$ & $\begin{array}{l}1.250 \\
1.287\end{array}$ & $\begin{array}{l}0.229 \\
0.319\end{array}$ & $\begin{array}{l}269.3 \\
356.1\end{array}$ & pyrrhotite* \\
\hline LMP107B2 & diorite porphyry & 2.771 & 1.40 & $\begin{array}{l}3057 \\
3716\end{array}$ & $\begin{array}{l}1.340 \\
1.353\end{array}$ & $\begin{array}{l}-0.064 \\
-0.023\end{array}$ & $\begin{array}{l}584.1 \\
440.0\end{array}$ & pyrrhotite* \\
\hline LMP107B3 & diorite porphyry & 2.714 & 1.20 & $\begin{array}{l}9961 \\
7783\end{array}$ & $\begin{array}{l}1.319 \\
1.332\end{array}$ & $\begin{array}{l}0.147 \\
0.392\end{array}$ & $\begin{array}{l}1355.0 \\
1043.0\end{array}$ & pyrrhotite* \\
\hline LMP107M & kersantite & 2.791 & 1.10 & $\begin{array}{l}3824 \\
4817\end{array}$ & $\begin{array}{l}1.092 \\
1.101\end{array}$ & $\begin{array}{l}0.148 \\
0.012\end{array}$ & $\begin{array}{r}859.5 \\
2352\end{array}$ & pyrrhotite and rare mineral with $\mathrm{T}_{\mathrm{C}}=150^{\circ} \mathrm{C}^{*}$ \\
\hline LA107D1 & kersantite & 2.819 & 0.88 & $\begin{array}{l}394 \\
395\end{array}$ & $\begin{array}{l}1.026 \\
1.012\end{array}$ & $\begin{array}{l}0.504 \\
0.674\end{array}$ & $\begin{array}{l}0.5 \\
0.1\end{array}$ & Cr-spinelides \\
\hline LA107D2 & kersantite & 2.858 & 0.46 & 7352 & 1.171 & -0.676 & 2842 & pyrrhotite* \\
\hline LA107D4 & kersantite & 2.816 & 0.70 & $\begin{array}{l}1081 \\
1261\end{array}$ & $\begin{array}{l}1.101 \\
1.096\end{array}$ & $\begin{array}{l}0.285 \\
0.509\end{array}$ & $\begin{array}{l}369 \\
435\end{array}$ & pyrrhotite $(* *)$, Cr-spinelide $(* *)$ \\
\hline LA107D5 & kersantite & 2.862 & 0.58 & $\begin{array}{l}6379 \\
6713\end{array}$ & $\begin{array}{l}1.111 \\
1.120\end{array}$ & $\begin{array}{r}0.171 \\
-0.078\end{array}$ & $\begin{array}{l}2126 \\
2261\end{array}$ & pyrrhotite* \\
\hline LMP108B & kersantite & 2.872 & 1.20 & $\begin{array}{l}4489 \\
3891\end{array}$ & $\begin{array}{l}1.092 \\
1.080\end{array}$ & $\begin{array}{l}0.711 \\
0.193\end{array}$ & $\begin{array}{l}859.5 \\
841.5\end{array}$ & $\begin{array}{l}\text { pyrrhotite*and rare mineral with } \mathrm{T}_{\mathrm{C}}=150^{\circ} \mathrm{C}^{*} \\
\text { Ti-mineral }(* *)\end{array}$ \\
\hline LMP109B & diorite porphyry & 2.734 & 5.70 & 261 & 1.034 & 0.530 & 0.4 & n.d. \\
\hline LMP109/2 & kersantite & 2.784 & 0.60 & $\begin{array}{l}7128 \\
7206\end{array}$ & $\begin{array}{l}1.170 \\
1.135\end{array}$ & $\begin{array}{r}-0.371 \\
0.250\end{array}$ & $\begin{array}{l}1835.0 \\
2220.0\end{array}$ & pyrrhotite*, Cr-spinelides, magnetite? $(* *)$ \\
\hline LA109D1 & quartz diorite porphyry & 2.727 & 1.18 & 255 & 1.011 & 0.802 & 1.3 & ilmenite, pyrite? $(* *)$ \\
\hline LMP110B & microgranite & 2.651 & 4.18 & $\begin{array}{l}40.7 \\
40.4\end{array}$ & $\begin{array}{l}1.014 \\
1.031\end{array}$ & $\begin{array}{r}-0.111 \\
0.171\end{array}$ & $\begin{array}{l}0.3 \\
0.1\end{array}$ & n.d. \\
\hline LA110D1 & microgranite & 2.611 & 0.67 & 30.0 & 1.075 & 0.310 & 0.5 & n.d. \\
\hline LA110D2 & microgranite & 2.614 & 1.98 & 7.0 & 1.063 & 0.173 & 0.2 & n.d. \\
\hline LMP111/2 & diorite porphyry & 2,798 & 0,6 & 387 & 1,033 & 0,759 & 0,85 & n.d. \\
\hline LMP111/3/1 & kersantite & 2.821 & 0.2 & 483 & 1.007 & -0.978 & 0.8 & n.d. \\
\hline LMP111/3/2 & kersantite & 2.896 & 0.6 & nd.. & nd. & nd. & nd. & n.d. \\
\hline LMP114 & kersantite & 2.859 & 0.2 & $\begin{array}{l}594 \\
555\end{array}$ & $\begin{array}{l}1.011 \\
1.013\end{array}$ & $\begin{array}{r}-0.006 \\
0.002\end{array}$ & $\begin{array}{l}0.5 \\
0.3\end{array}$ & biotitized $(* *)$, n.d. \\
\hline LMP117 & diorite porphyry & 2.813 & 0.5 & $\begin{array}{l}487 \\
496\end{array}$ & $\begin{array}{l}1.007 \\
1.008\end{array}$ & $\begin{array}{l}-0.921 \\
-0.541\end{array}$ & $\begin{array}{l}0.8 \\
1.2\end{array}$ & strongly biotitized $(* *)$, n.d. \\
\hline LMP118 & kersantite & 2.802 & 1.0 & 474 & 1.009 & -0.075 & 0.9 & chloritized $(* *)$, n.d. \\
\hline LMP119 & spessartite & 2.842 & 0.8 & 463 & 1.004 & -0.098 & 7.2 & very rare $\mathrm{Fe}$-Ti mineral, $\mathrm{T}_{\mathrm{C}}=560^{\circ} \mathrm{C}^{*}$ \\
\hline LMP121 & kersantite & 2.864 & 0.3 & $\begin{array}{l}684 \\
713\end{array}$ & $\begin{array}{l}1.009 \\
1.013\end{array}$ & $\begin{array}{l}0.056 \\
0.123\end{array}$ & $\begin{array}{l}0.2 \\
0.3\end{array}$ & paramagnetic* \\
\hline LMP124 & kersantite & 2.848 & 1.1 & $\begin{array}{l}449 \\
454\end{array}$ & $\begin{array}{l}1.014 \\
1.016\end{array}$ & $\begin{array}{l}0.452 \\
0.376\end{array}$ & $\begin{array}{l}0.8 \\
1.1\end{array}$ & n.d. \\
\hline LMP130 & minette & 2.794 & 5.1 & 359 & 1.016 & -0.275 & 2.9 & Fe-Ti mineral, very rare, $T_{C}=470^{\circ} \mathrm{C}^{*}$ \\
\hline LMP131 & minette & 2.766 & 6.29 & $\begin{array}{l}353 \\
368\end{array}$ & $\begin{array}{l}1.012 \\
1.010\end{array}$ & $\begin{array}{l}-0.275 \\
-0.108\end{array}$ & $\begin{array}{l}2.5 \\
4.2\end{array}$ & n.d. \\
\hline LMP132 & diorite porphyry & 2.705 & 1.4 & $\begin{array}{l}276 \\
281\end{array}$ & $\begin{array}{l}1.008 \\
1.012\end{array}$ & & $\begin{array}{l}0.2 \\
0.2\end{array}$ & chloritized $(* *)$, n.d. \\
\hline LMP133 & quartz diorite porphyry & 2.742 & 0.4 & $\begin{array}{l}253 \\
268\end{array}$ & $\begin{array}{l}1.022 \\
1.016\end{array}$ & $\begin{array}{r}-0.456 \\
0.175\end{array}$ & $\begin{array}{l}2.9 \\
1.7\end{array}$ & very rare pyrrhotite* \\
\hline LMP133M & diorite porphyry & 2.805 & 1.2 & 372 & 1.016 & 0.367 & 2.2 & very rare pyrrhotite* \\
\hline LMP135 & kersantite & 2.876 & 1.0 & $\begin{array}{l}473 \\
468\end{array}$ & $\begin{array}{l}1.011 \\
1.009\end{array}$ & $\begin{array}{r}0.177 \\
-0.277\end{array}$ & $\begin{array}{l}5.0 \\
0.7\end{array}$ & ilmenite $(* *), \mathrm{Cr}$-spinelides $(* *)$ \\
\hline LMP136A & kersantite & 2.847 & 0.7 & $\begin{array}{l}474 \\
469\end{array}$ & $\begin{array}{l}1.008 \\
1.008\end{array}$ & $\begin{array}{l}-0.104 \\
-0.279\end{array}$ & $\begin{array}{l}0.8 \\
0.5\end{array}$ & n.d. \\
\hline LMP136B & kersantite & 2.850 & 1.5 & $\begin{array}{l}484 \\
473\end{array}$ & $\begin{array}{l}1.009 \\
1.009\end{array}$ & $\begin{array}{l}0.275 \\
0.195\end{array}$ & $\begin{array}{l}0.5 \\
0.5\end{array}$ & n.d. \\
\hline LMP138 & kersantite & 2.784 & 0.5 & 366 & 1.052 & 0.125 & 11.2 & traces of pyrrhotite* \\
\hline LMP140 & kersantite & 2.812 & 0.9 & $\begin{array}{l}505 \\
350\end{array}$ & $\begin{array}{l}1.086 \\
1.072\end{array}$ & $\begin{array}{l}0.583 \\
0.743\end{array}$ & $\begin{array}{r}18.9 \\
5.7\end{array}$ & pyrrhotite* \\
\hline LMP142M1 & granite porphyry & 2.616 & 1.07 & $\begin{array}{r}101 \\
95\end{array}$ & $\begin{array}{l}1.023 \\
1.018\end{array}$ & $\begin{array}{l}0.844 \\
0.410\end{array}$ & $\begin{array}{l}0.8 \\
0.5\end{array}$ & n.d. \\
\hline LMP142M2 & granite porphyry & 2.605 & 0.76 & $\begin{array}{l}88 \\
92\end{array}$ & $\begin{array}{l}1.019 \\
1.028\end{array}$ & $\begin{array}{l}0.311 \\
0.341\end{array}$ & $\begin{array}{l}2.4 \\
1.5\end{array}$ & n.d. \\
\hline LMP142M3 & granite porphyry & 2.628 & 0.80 & $\begin{array}{l}26 \\
29\end{array}$ & $\begin{array}{l}1.114 \\
1.019\end{array}$ & $\begin{array}{l}0.038 \\
0.874\end{array}$ & $\begin{array}{l}1.2 \\
5.2\end{array}$ & n.d. \\
\hline LMP142M4 & granite porphyry & 2.627 & 0.61 & $\begin{array}{l}49 \\
49\end{array}$ & $\begin{array}{l}1.056 \\
1.061\end{array}$ & $\begin{array}{l}0.609 \\
0.406\end{array}$ & $\begin{array}{l}0.2 \\
0.4\end{array}$ & n.d. \\
\hline LMP142M5 & granite porphyry & 2.629 & 0.72 & $\begin{array}{l}43 \\
46\end{array}$ & $\begin{array}{l}1.019 \\
1.033\end{array}$ & $\begin{array}{l}0.623 \\
0.037\end{array}$ & $\begin{array}{l}2.4 \\
1.2\end{array}$ & n.d. \\
\hline
\end{tabular}


Tab. 8 continued

\begin{tabular}{|c|c|c|c|c|c|c|c|c|}
\hline LMP145 & meladiorite porphyry & 2.838 & 0.80 & $\begin{array}{l}459 \\
465\end{array}$ & 1.006 & $\begin{array}{l}-0.539 \\
-0.530\end{array}$ & 0.6 & pyrrhotite* \\
\hline LMP147 & granite porphyry & 2.614 & 0.72 & $\begin{array}{l}403 \\
56 \\
55\end{array}$ & $\begin{array}{l}1.000 \\
1.035 \\
1.027\end{array}$ & $\begin{array}{r}-0.530 \\
-0.043 \\
0.307\end{array}$ & $\begin{array}{l}1.1 \\
0.3 \\
0.4\end{array}$ & chloritized $(* *)$ \\
\hline LMP148 & kersantite & 2.822 & 1.20 & $\begin{array}{r}428 \\
407\end{array}$ & $\begin{array}{l}1.027 \\
1.005 \\
1.004\end{array}$ & $\begin{array}{r}0.757 \\
-0.640\end{array}$ & $\begin{array}{l}0.4 \\
0.9 \\
1.0\end{array}$ & very rare $\mathrm{Fe}$-Ti mineral with $\mathrm{T}_{\mathrm{C}}=570^{\circ} \mathrm{C}^{*}$ \\
\hline LMP149 & granite porphyry & 2.635 & 0.75 & $\begin{array}{l}46 \\
51\end{array}$ & $\begin{array}{l}1.092 \\
1.113\end{array}$ & $\begin{array}{r}0.939 \\
-0.682\end{array}$ & $\begin{array}{r}0.2 \\
19.6\end{array}$ & n.d. \\
\hline LA171 & minette & 2.799 & 1.18 & 412 & 1.023 & 0.958 & 4.5 & n.d. \\
\hline LA171M & minette & 2.786 & 1.34 & 380 & 1.020 & 0.572 & 4.0 & $\begin{array}{l}\text { very rare } \mathrm{Fe} \text {-Ti minerals, } \\
\text { with } \mathrm{T}_{\mathrm{C}}=470^{\circ} \mathrm{C} \text { and } 560^{\circ} \mathrm{C} * \text {; chloritized }(* *)\end{array}$ \\
\hline LA172 & minette & 2.793 & 5.75 & 329 & 1.021 & 0.682 & 2.2 & n.d. \\
\hline LA173 & minette & 2.775 & 7.85 & 287 & 1.018 & 0.710 & nd. & n.d. \\
\hline LA174 & minette & 2.788 & 1.23 & $\begin{array}{l}351 \\
276\end{array}$ & $\begin{array}{l}1.037 \\
1.025\end{array}$ & $\begin{array}{l}0.777 \\
0.733\end{array}$ & $\begin{array}{l}2.8 \\
4.0\end{array}$ & n.d. \\
\hline LA174M & minette & 2.777 & 1.91 & 395 & 1.012 & 0.674 & 3,5 & chloritized $(* *)$, n.d. \\
\hline LA178 & diorite porphyry & 2.805 & 0.05 & 413 & 1.011 & 0.218 & 0.7 & n.d. \\
\hline LA180 & spessartite & 2.847 & 0.20 & 525 & 1.009 & -0.619 & nd. & biotititized $(* *)$, n.d. \\
\hline LA182 & spessartite & 2.875 & 0.39 & $\begin{array}{l}553 \\
515\end{array}$ & $\begin{array}{l}1.008 \\
1.009\end{array}$ & $\begin{array}{l}0.685 \\
0.664\end{array}$ & $\begin{array}{l}6.9 \\
5.7\end{array}$ & very rare pyrrhotite*,biotitized $(* *)$ \\
\hline LA185 & quartz kersantite & 2.728 & 0.23 & 347 & 1.027 & -0.644 & 1.0 & n.d. \\
\hline
\end{tabular}

Explanations: Dg - grain density; Por - open porosity, Km - mean magnetic susceptibility; P - degree of anisotropy; T - shape factor of magnetic fabric; NRM - natural remanent magnetization

* - mineral was identified by magnetic thermoanalysis; $(* *)$ - identification in thin sections; n.d. - no thermoanalysis was carried out

Tab. 9 Statistical parameters for distribution of the grain densities and magnetic properties of dykes in the Jáchymov ore district

\begin{tabular}{|c|c|c|c|c|c|c|}
\hline Petrographic type & Statistical parameter & $\operatorname{Dg}\left(\mathrm{g} \mathrm{cm}^{-3}\right)$ & $\mathrm{Km}\left(10^{-6} \mathrm{SI}\right)$ & $\mathrm{P}$ & $\mathrm{T}$ & NRM (NT) \\
\hline \multirow{3}{*}{$\begin{array}{l}\text { minette } \\
\mathrm{n}=9(8)\end{array}$} & ME & 2.787 & 353 & 1.020 & 0.682 & 3.45 \\
\hline & $\mathrm{AM}$ & 2.785 & 346 & 1.020 & 0.399 & 3.39 \\
\hline & $\mathrm{SD}$ & 0.010 & 41 & 0.008 & 0.497 & 0.82 \\
\hline \multirow{3}{*}{$\begin{array}{l}\text { kersantite with } \\
\text { ophitic texture, } \\
\text { magnetic; } n=11 \text { (6) }\end{array}$} & $\mathrm{ME}$ & 2.837 & 4817 & 1.111 & 0.171 & 2030 \\
\hline & $\mathrm{AM}$ & 2.830 & 4397 & 1.113 & 0.095 & 1535 \\
\hline & $\mathrm{SD}$ & 0.034 & 2606 & 0.035 & 0.411 & 963 \\
\hline \multirow{3}{*}{$\begin{array}{l}\text { kersantite with } \\
\text { ophitic texture, } \\
\text { non-magnetic, } n=6\end{array}$} & $\mathrm{ME}$ & 2.822 & 418 & 1.010 & 0.340 & 0.80 \\
\hline & $\mathrm{AM}$ & 2.839 & 428 & 1.011 & 0.199 & 1.37 \\
\hline & SD & & 32 & 0.007 & 0.510 & 0.32 \\
\hline \multirow{3}{*}{$\begin{array}{l}\text { kersantite } \\
\mathrm{n}=13\end{array}$} & ME & 2.849 & 483 & 1.011 & 0.123 & 0.50 \\
\hline & $\mathrm{AM}$ & 2.850 & 514 & 1.021 & 0.112 & 1.99 \\
\hline & SD & 0.023 & 95 & 0.025 & 0.416 & 3.70 \\
\hline \multirow{3}{*}{$\begin{array}{l}\text { spessartite } \\
\mathrm{n}=6(3)\end{array}$} & ME & 2.847 & 490 & 1.007 & 0.557 & 5.70 \\
\hline & $\mathrm{AM}$ & 2.853 & 497 & 1.007 & 0.579 & 4.30 \\
\hline & $\mathrm{SD}$ & & 36 & 0.002 & 0.191 & 2.90 \\
\hline \multirow{3}{*}{$\begin{array}{l}\text { diorite porphyry, } \\
\text { magnetic, } n=6 \text { (3) }\end{array}$} & ME & 2.734 & 3800 & 1.326 & 0.188 & 512 \\
\hline & $\mathrm{AM}$ & 2.740 & 5305 & 1.314 & 0.167 & 675 \\
\hline & SD & & 2612 & 0.035 & 0.167 & 393 \\
\hline \multirow{3}{*}{$\begin{array}{l}\text { diorite porphyry, } \\
\text { non-magnetic } \\
n=11(8)\end{array}$} & $\mathrm{ME}$ & 2.798 & 281 & 1.012 & 0.197 & 0.80 \\
\hline & $\mathrm{AM}$ & 2.769 & 341 & 1.016 & 0.230 & 1.05 \\
\hline & SD & 0.043 & 90 & 0.009 & 0.416 & 0.70 \\
\hline \multirow{3}{*}{$\begin{array}{l}\text { granite porphyry } \\
\mathrm{n}=18^{*}(10)\end{array}$} & $\mathrm{ME}$ & 2.622 & 46 & 1.033 & 0.310 & 0.50 \\
\hline & $\mathrm{AM}$ & 2.623 & 52 & 1.047 & 0.303 & 1.05 \\
\hline & SD & 0.013 & 25 & 0.032 & 0.388 & 1.26 \\
\hline
\end{tabular}

ME - median; AM - arithmetic mean; SD - standard deviation;

$\mathrm{n}$ - number of samples measured by magnetometry; (in parentheses) - number of samples measured for grain density 
of $10^{-3}[\mathrm{SI}]$ have been found in kersantites and diorite porphyries from the Jáchymov quarry. Field measurements of the mafic dykes at the margins of the granite porphyry dyke (Fig. 8) showed parts with increased magnetic susceptibility, in which pyrrhotite was observed by naked eye.

\subsection{Thermoanalysis}

Thermoanalyses confirmed the presence of monoclinic pyrrhotite in lamprophyres from the Jáchymov quarry (Fig. 21). Pyrrhotite in this sample is indicated by a sudden decrease on the heating curve at $320^{\circ} \mathrm{C}$, which is the $\mathrm{T}_{\mathrm{C}}$ (the temperature of the Curie point) of monoclinic pyrrhotite (Dunlop and Özdemir 1997). The other peak between 500 and $600{ }^{\circ} \mathrm{C}$ corresponds to the origin of magnetite by oxidation, which continues during cooling. At $340{ }^{\circ} \mathrm{C}$ the curve indicates the probable appearance of maghemite. By the same method pyrrhotite was identified also in some other kersantite localities. The presence of pyrrhotite causes anomalous susceptibilities and conspicuously increased P coefficients of anisotropy and NRM values. Pyrrhotite (namely its monoclinic modification) shows anomalous magnetic crystal anisotropy, which is 1000 times lower along the Z-axis than parallel to its base. Besides pyrrhotite, other magnetic accessories as magnetite are present in very small amounts. By this feature lamprophyres differ from basalts, in which a substantial amount of magnetite belongs to their typical mineralogical characteristics.

The magnetic minerals that were identified by the thermoanalysis resemble by their $\mathrm{T}_{\mathrm{C}}$ the magnetites with admixtures of $\mathrm{Ti}, \mathrm{Cr}$ or some other trace elements. The presence of magnetite or pyrite could not be proven in most curves because magnetite or maghemite originate, albeit in relatively small amounts, during heating as a consequence of pyrite decomposition. A significant difference between the heating and cooling curves (Fig. 21) provides an indirect evidence for thermal instability of mineral assemblage in Jáchymov lamprophyres and indicates that the lamprophyres could have originally been more magnetic. Changes on heating and cooling may have occurred in spinelides, which commonly formed at the magmatic stage.

\subsection{Magnetic anisotropy}

The lamprophyres without, or with only traces of pyrrhotite show anomalously small magnetic anisotropy, characterized by $\mathrm{P}$ values $c .1 .010$ or even less (Tab. 8, Fig. 22) and thus appear as nearly isotropic. Very low values of the magnetic anisotropy P testify to randomly oriented internal magnetic structure, which indicates lack of any preferred orientation of micas and amphiboles.
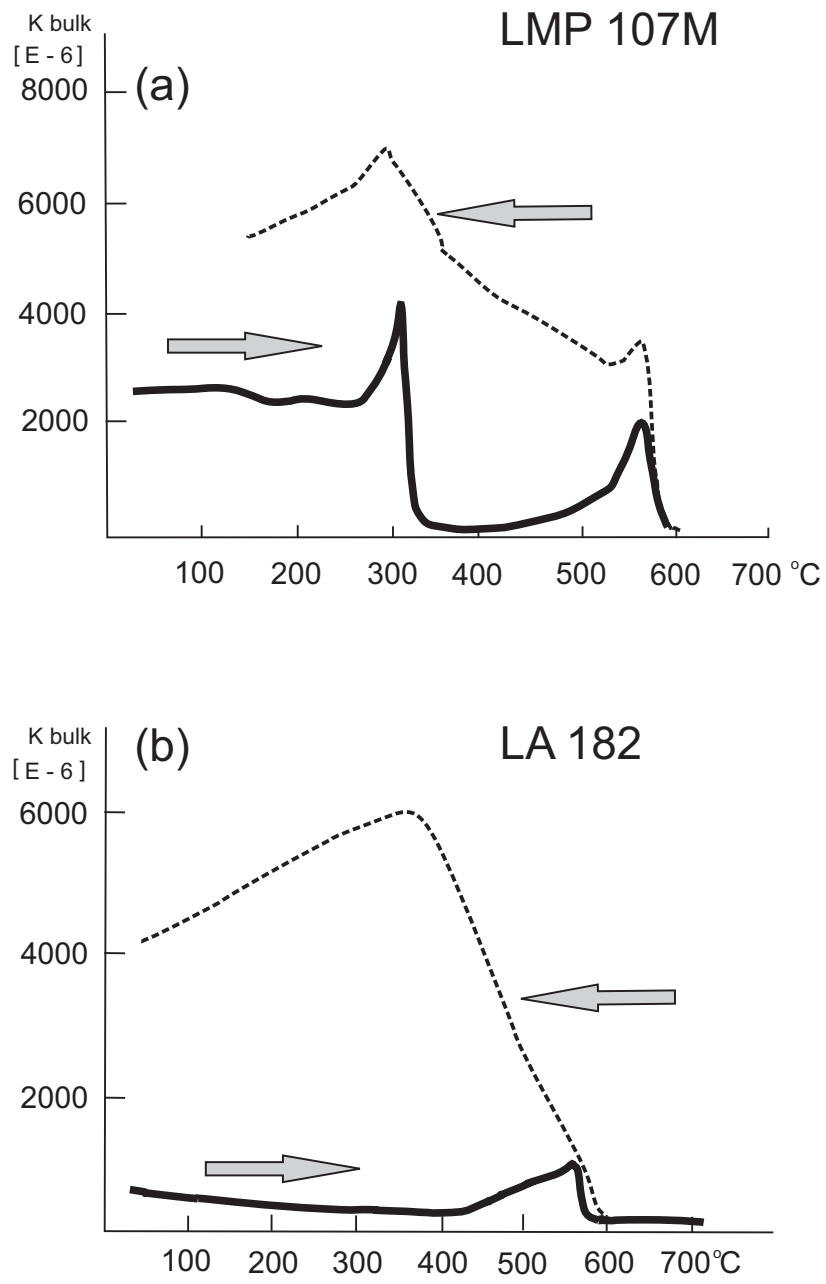

Fig. 21 Variation of magnetic susceptibility with temperature on heating and cooling (a) in kersantite from the Jáchymov quarry, (b) in spessartite from the Barbora mine.

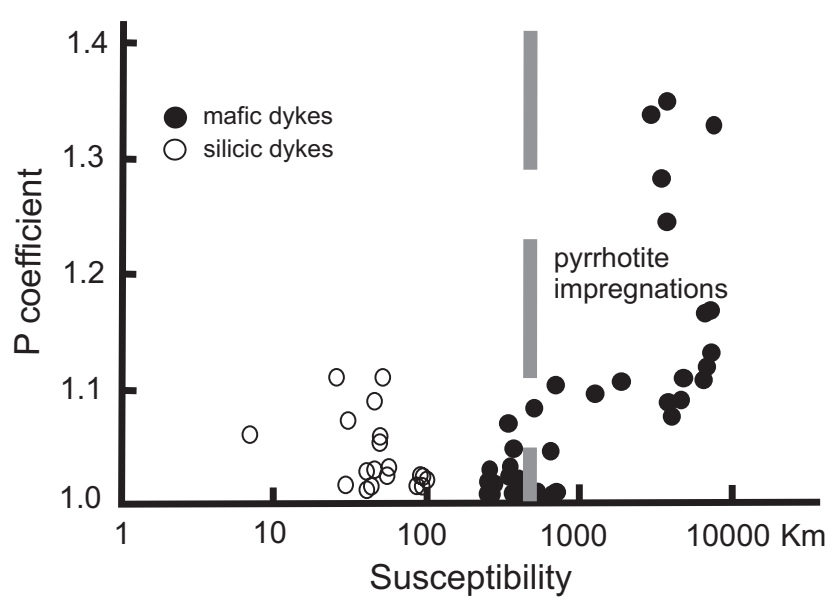

Fig. 22 Coefficients of anisotropy (P) versus magnetic susceptibility in mafic and silicic dykes of the Jáchymov ore district. 
The internal structure of lamprophyres was affected by uralitization and secondary biotitization. For instance, in the sample of kersantite from the Jáchymov quarry (LA 109/2), skeletal aggregates of pyrrhotite impregnating uralite pseudomorphs and accumulations of biotite were observed under microscope. Pilite pseudomorphs contain in places tiny grains of $\mathrm{Cr}$-spinelides. It is hard to decipher solely on textural grounds, whether these are primary or secondary having originated during deuteric and postmagmatic alterations.

Pyrrhotite is a very significant carrier of natural remanent magnetization. However, as the specimens lacking pyrrhotite show, there is always present at least one additional ferromagnetic mineral such as hematite or lepidocrocite in all mafic dyke rocks responsible for the NRM values measured.

Low values of magnetic susceptibility in silicic rocks are in agreement with their predominant quartz-feldspar composition and a very low content of ferromagnetic minerals. Hematite pigment present in most of them in variable amounts does not affect the measured values of magnetic anisotropy but it can act as a carrier of natural remanent magnetization.

\section{Discussion}

The Variscan dyke assemblage in the Jáchymov ore district is spatially associated with the exocontact of the Variscan WKEP. The contact served as a tectonically active zone within the NW trending Jáchymov-Gera Lineament. A characteristic feature of the Jáchymov district is an intimate association of mafic and silicic dykes, which occupy different fault systems and, rarely, form composite dykes. Lamprophyres belong predominantly to kersantites characterized by the presence of dark mica phenocrysts and variable amounts of amphibole, most of which is secondary. The occurrences of plagioclase phenocrysts indicate transitions of these lamprophyres to diorite porphyries, which are clearly the youngest of mafic dykes in the district. This is also evidenced by intersecting the dykes of microgranite by these mafic dykes. No minettes were found in a direct association with kersantites. The minette we studied formed a separate occurrence within the OIC granite. In a similar geological position Sattran (1965) described fine-grained quartz diorite porphyry (classified as 'porphyrite') intersecting biotite OIC granite ('biotite adamellite') near the elevation of Popovský kříž, about 5 km SW of Jáchymov.

Silicic dykes are mostly represented by granite porphyries characterized by abundant phenocrysts of quartz and feldspars in the fine-grained matrix. According to Sattran (1965), these porphyries occur in two age sequences differring in rock colours (grey and pink). However, it is also possible that the two granite porphyry varieties are simply an expression of a variable late hematitization, effects of which are observed in various igneous rocks and also in ore veins.

The rhyolitic compositions are rare among the dyke rocks in the district. We observed only a single dyke, which had a two-phase texture similar to that described from Doubí near Karlovy Vary by Štemprok et al. (2008). The typical fluidal textures noted in rhyolites crosscutting the granites in the Eibenstock part of the WKEP were not observed in course of the present study. However, their weak development was recognized within the textures of some phenocryst-poor granite porphyries found on the dumps.

The exact age relationship between the mafic dykes and the granites is poorly constrained as no contact of the petrographically studied lamprophyre was documented from the mine workings. Literature data suggest that kersantites were earlier than spessartites. Lamprophyres occur in a close association with diorite porphyries and may pass into each other within a single dyke. The temporal relations between the lamprophyres and felsic rocks are controversial, according to the numerous available observations. Our new finding confirmed the intersection of a phenocryst-poor dyke of granite porphyry (microgranite) by a dyke of dioritic porphyry, which may be classified as a LD3 lamprophyre sensu Seifert (2007). These could be possibly the youngest lamprophyres observed in the cross sections through the mines by Veselý (1986b).

Literature data point also to variable crosscutting relationships between various types of lamprophyres as well as between lamprophyres and silicic dykes. These data cannot be newly verified as the majority of mine workings is not accessible anymore. It is difficult to identify the earlier generation of lamprophyres because granites were not in a close contact with the mapped occurrences of lamprophyres in the mines (Veselý 1986a, b). Our geochemical studies show that the composition of the Jáchymov kersantites is identical, or at least very similar to the early LD1 lamprophyres (kersantites) from the Ehrenfriedersdorf reported by Seifert (2007). Using this classification scheme it is possible to speculate that the pre-granitic lamprophyres LD1 occur in the Jáchymov ore district but no direct proof is available yet.

All lamprophyres are much affected by deuteric alterations, which have changed the primary magmatic composition and textures (pilitization of olivine, uralitization of pyroxenes). As a consequence of massive pilitization, no olivine has been preserved in the samples examined. Additionally, in most samples of kersantites, clinopyroxenes have been transformed to actinolitic amphibole by uralitization. Such an alteration is probably the most severe among the lamprophyres known in the Bohemian Massif. 
Most dyke rocks are potassium-rich, ranging from highly potassic to ultrapotassic in various classifications (Rollinson 2003). The major-element composition of the Jáchymov kersantites is close to the average world kersantite chemistry reported by Rock (1991) (Figs 13 and 14). On the other hand, the Jáchymov lamprophyres show lower contents of transition elements (Fig. 14). Kersantites are significantly enriched in $\mathrm{Sn}, \mathrm{U}, \mathrm{Th}, \mathrm{Rb}$, Cs and partly in Hf. Mafic dykes are partly influenced by greisenization, which is closely connected with the occurrences of YIC granites underlaying the Jáchymov ore district. This process may have led to an increase in $\mathrm{F}, \mathrm{Li}, \mathrm{Rb}$ and $\mathrm{Cs}$ contents in some of the samples. To distinguish whether the increased concentration of these elements in the mafic dykes is due to an enrichment inherited from the mantle source or caused by secondary processes is, however, not possible.

Mafic dykes host sulphides, arsenides and carbonates and this suggests that the host rocks were affected by hydrothermal fluids related to the origin of ore veins. However, detailed studies of the $\mathrm{U}$ distribution confirmed that the mafic dykes have low uranium contents and lack of uraninite or coffinite, elsewhere the major carriers of the uranium mineralization. Also, the literature data do not show that the position of the lamprophyre dykes would control the localization of uranium-bearing ore shoots (Topinka 1979; Veselý 1986b). Mafic dykes have increased Th but its primary host is so far poorly known.

The binary variation diagrams (Figs 13-14 and 16) feature a distinct gap between the compositions of lamprophyres, diorite porphyries and silicic dykes. Mafic dykes contain commonly secondary carbonates, presence of which proves that the rocks were permeable to hydrothermal solutions, which apparently deposited carbonates in the vein fillings at the time of the uranium mineralization. These processes might have affected the trace-element composition of some mafic dykes.

The existence of lamprophyres coeval with Variscan ore mineralization has been taken as an evidence for the mantle influence in various regions of the Erzgebirge/ Krušné hory (Kramer 1976, 1988; Seifert and Baumann 1994; Seifert 1997). A causal connection between mantle-derived heat/material and the formation of various Variscan and subsequent mineralizations has been postulated on this basis. Importantly, the emplacement of mafic and silicic magmas was repeated during the whole long history of Late Variscan magmatism in the region (325 to $290 \mathrm{Ma}$ ) and it was accompanied with and followed by various stages of mineralizations. The occurrences of lamprophyres mark the crustal sections accessible to mantle-derived magmas that not necessarily contributed to ore specialization of granitic magma sources. However, their effect on the temperature regime of the tectonically weakened zones was likely substantial. These weakened zones could have been also the pathways for fluids derived from a subducted continental lithosphere to the upper crust. Such fluids could have affected granitic sources and have been responsible for their ore specialization. All the calc-alkaline lamprophyre magmas tend to be contaminated by the continental crust to some extent (Rock 1991). This makes the search for a primary source difficult. It is impossible to constrain the nature and chemistry of primary magmas to the lamprophyres in the Krušné hory/Erzgebirge for two main reasons: (1) the dykes were strongly influenced by deuteric to early post-magmatic alteration processes subsequent to emplacement of hydrous mafic magmas and (2) the dyke rocks are spatially associated with the Variscan mineralization processes, whose parental fluids invaded the associated dykes. These fluids deposited epigenetic carbonates, sulphides or arsenides, which were documented in some specimens of the dyke rocks from the Jáchymov district.

Variations of $\mathrm{mg} \#$ [i.e. molar ratio $\mathrm{MgO} /(\mathrm{MgO}+$ $\left.\mathrm{FeO}_{\mathrm{t}}\right)$ ] and k\# [i.e. molar ratio of $\mathrm{K}_{2} \mathrm{O} /\left(\mathrm{K}_{2} \mathrm{O}+\mathrm{Na}_{2} \mathrm{O}\right)$ ] values provide useful means to compare of the degree of primary character and that of metasomatic enrichment (Fig. 23). In the mg\# vs. MgO diagram (Fig. 23a) lamprophyres span a transitional array between durbachites, which are more primitive, and shoshonitic and alkaline suites, which are more fractionated. In terms of their $\mathrm{mg} \#$ values, the lamprophyres overlap with the least evolved members of the redwitzite suite in the Erzgebirge and the Northern Oberpfalz. Variation of $\mathrm{k \#} v s . \mathrm{MgO}$ (Fig. 23b) allows a closer separation of the degree of mantle enrichment prior to the Variscan partial melting event. Lamprophyres define a broad field bracketed by durbachites ( $\mathrm{k} \#=0.55$ to 0.75$)$, the redwitzite and appinite suites $(\mathrm{k} \#=0.25$ to 0.50$)$. It is worth noting that the diorite porphyries show a clear geochemical overlap with the most evolved members of the redwitzite suite in the Northern Oberpfalz. From this point of view, both the diorite porphyries and the redwitzites seem to represent geochemically similar but texturally distinct products of magma mixing between primary mantle-derived melts and continental material (Kováŕíková et al. 2007). They were probably produced (nearly?) contemporaneously during the late stages of the Variscan magmatism.

Because the $\mathrm{K}_{2} \mathrm{O}$ contents in lamprophyres are constantly high (Fig. 13), the presence of phlogopite in the mantle source is to be assumed (Foley 1990; Edgar and Vukadinovic 1992; Wunder and Melzer 2003), These could have been larger phlogopitic harzburgite regions in the mantle or increased concentrations of phlogopite or some other minerals (e.g. apatite) in the dyke-like or schlieren-like portions of the mantle, which originated by passage of fluids or melts (Foley 1990, 1992; Foley et al. 1987, 2000). In the case of spessartite or some transitional types between kersantites and spessartites it 

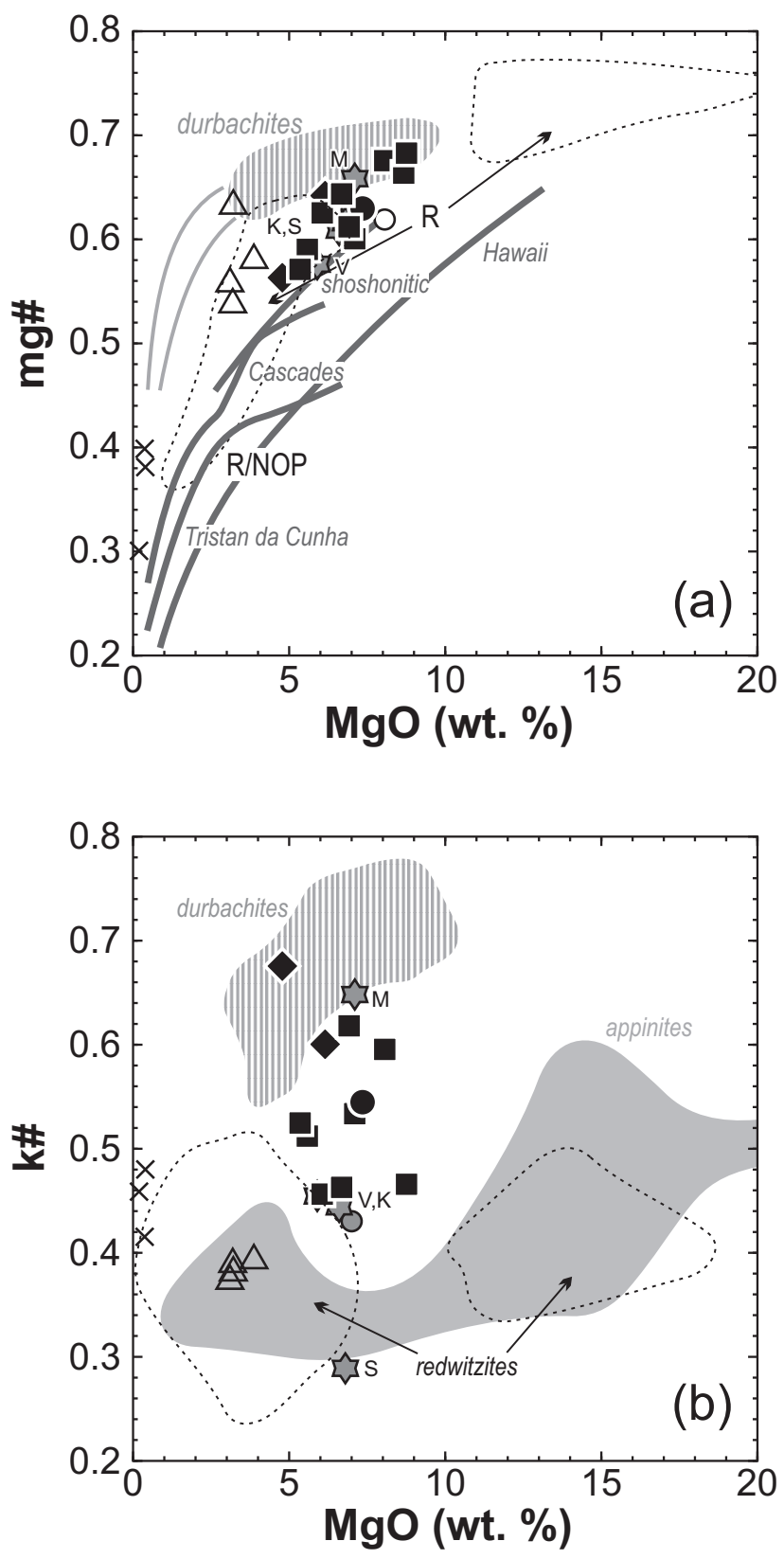

Fig. 23 Variation diagram of $\mathrm{mg}$ and $\mathrm{k}$ numbers vs. $\mathrm{MgO}$ in dykes of the Jáchymov ore district. For comparison are shown fields of durbachites (Holub 1997), appinites (Hamidullah and Bowes 1987) and redwitzites (Troll 1968; Siebel 1993; Kováŕíková 2007). For explanation see Fig. 12 .

Fig. 24 The diagrams of $\mathrm{Ca} / \mathrm{Pb}$ vs. $\mathrm{Ce}(\mathrm{a}), \mathrm{Nb} / \mathrm{U}$ vs. $\mathrm{U}(\mathrm{b})$ and $\mathrm{La} / \mathrm{Sm}$ vs. $\mathrm{La} / \mathrm{Ta}$ (c) of the dykes from the Jáchymov ore district compared with the average values for various lithological units of the continental crust and reservoirs of the primitive mantle (according to Sun and McDonough 1989; McDonough and Sun 1995; Rudnick and Gao 2003), field of the lamprophyres from the Western Alps (WA), and pelagic sediments are according to Owen (2008). For explanation see Fig. 12.
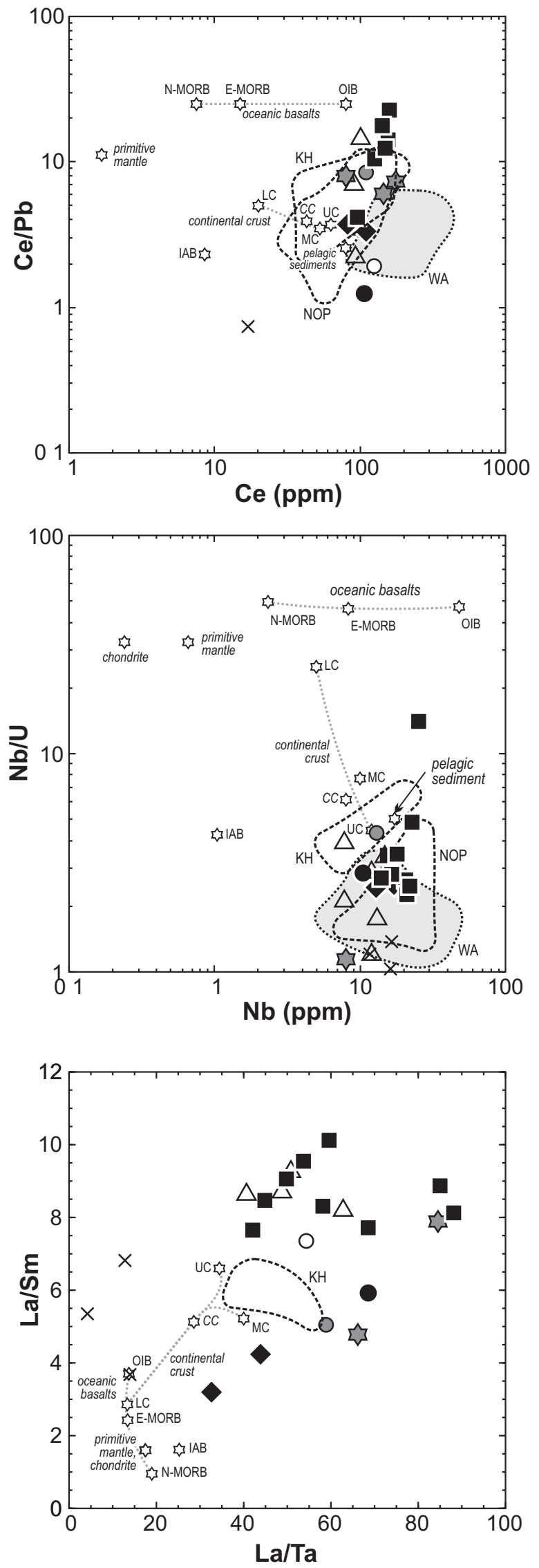
is possible to consider that the mantle source contained also amphibole. Their chemistry may be, however, related to somewhat different conditions and degree/mechanism of the enrichment processes or partly to a lower degree of melting.

We propose that subducted sediments could have been a plausible source for increased $\mathrm{K}_{2} \mathrm{O}$, Ba and $\mathrm{P}$ concentrations observed in lamprophyric melts (see also Owen 2008). The $\mathrm{Ce} / \mathrm{Pb}$ ratios of the Jáchymov lamprophyres are mostly below the range of primitive mantle and oceanic basalts. In contrast, they define a broad mixing trend between primitive-mantle (oceanic basalt) and subducted sedimentary components (Fig. 24a). In addition, the $\mathrm{Ce} / \mathrm{Pb}$ ratios of the K-rich lamprophyres overlap with those in lamprophyric magmas from the Western Alps, for which the involvement of subducted component has been independently confirmed by $\mathrm{Sr}-\mathrm{Nd}-\mathrm{Pb}$ isotope composition (Owen 2008). The hypothesis is also supported by very low $\mathrm{Nb} / \mathrm{U}$ ratios (2-12) (Fig. 24b). These geochemical features indicate possible sedimentary component and fluid fractionation of HFSE during slab devolatilization and subsequent enrichment in the mantle wedge. The $\mathrm{La} / \mathrm{Sm}$ vs. La/Ta diagram (Fig. 24c) supports enrichment in LREE as well as their decoupling from fluid-immobile HFSE (Baier et al. 2008).

According to mg\# values, concentrations of compatible trace elements such as $\mathrm{Cr}$ and $\mathrm{Ni}$, as well as the shape of the REE patterns, the Jáchymov lamprophyres represent products of a low-degree mantle melting. Relatively high contents of $\mathrm{Ni}$ and $\mathrm{Cr}$ and high mg\# values for some lamprophyres indicate primitive nature of the magma and a very small degree of differentiation (Esperanza and Holloway 1987; Rock 1991; Edgar and Mitchell 1997; Feng et al. 2004). Lamproite magmas (Bergman 1987), which appear as possible candidates for lamprophyric primary magmas (Rock 1991), are extremely vulnerable to crustal contamination. They have high volatile contents, low densities and viscosities and high hybridization potential, which makes their interaction with crustal melts rapid and efficient (Prelevic et al. 2004). Such mantle-derived lamproite melts did not find a free passage through the continental crust and were usually thoroughly modified by an uptake of the crustal components.

If we apply this hypothesis for the Krušné hory/Erzgebirge lamprophyres, the colinear behaviour of kersantites, porphyries and silicic rocks in many binary variation diagrams can be explained by hybridization of primary mafic magma by silicic component rather than by a closed-system fractional crystallization. The latter is not generally accepted as explanation for variations within lamprophyre clan because of their rapid emplacement and crystallization (Rock 1991). Thus, the variable degree of crustal contamination could be one of the main causes for the variability in the composition of principal groups of mafic dykes in the Jáchymov ore district. The composition of diorite porphyries can be well explained by mixing between the compositions of lamprophyres and silicic melts.

From the compositions of two end-member basic (mafic) and acid (felsic) magmas it is possible to calculate the chemistry of hybrid magmas according to the linear mixing relationship (Langmuir et al. 1978):

$$
\mathrm{C}_{\mathrm{M}}=\mathrm{X}_{\mathrm{A}} \times \mathrm{C}_{\mathrm{A}}+\left(1-\mathrm{X}_{\mathrm{A}}\right) \times \mathrm{C}_{\mathrm{B}}
$$

where

$\mathrm{C}_{\mathrm{M}}=$ concentration of the element in the hybrid melt, $\mathrm{C}_{\mathrm{A}}=$ concentration of the element in silicic component, $\mathrm{C}_{\mathrm{B}}=$ concentration of the element in mafic component, $\mathrm{X}_{\mathrm{A}}=$ the fraction of silicic component participating in mixing $(0-1)$.

In binary diagrams the diorite porphyries plot between the fields of silicic dykes and lamprophyres (Figs 13-15) and may therefore represent their mixtures. Thus lamprophyres and diorite porphyries seem to differ from each other by the degree of contamination by the crustal material. Using these calculations we can estimate the amount of acid component (corresponding to silicic magmas) added to a kersantite based on the average amounts of $\mathrm{CaO}, \mathrm{FeO}$ and $\mathrm{MgO}$ to be $c .40$ to 50 wt. \%. It is difficult to decipher, whether the contamination occurred via mixing of two contrasting magmas or the mafic magma simply assimilated crustal material of granitic composition. Given the absence of data on the primary lamprophyre magmas it is possible to accept both explanations.

Relative enrichment of light rare earth elements (LREE) and, large ion lithophile elements [LILE, e.g., $\mathrm{Cs}, \mathrm{Ba}, \mathrm{Rb}$ )] leading to increased LREE/HFSE and LILE/ HFSE ratios in lamprophyres is generally accepted as a consequence of enrichment processes caused by dehydration of subducted slabs (McNeil and Kerrich 1986; Foley et al. 2000; Feng et al. 2004). The lamprophyres from Jáchymov have also moderately increased contents of some high field strength elements (e.g. $\mathrm{Zr}, \mathrm{Hf}, \mathrm{Nb}$, and $\mathrm{Ta}$ ) and also relatively increased $\mathrm{Th} / \mathrm{Ta}$ ratios over average calc-alkaline lamprophyres (Rock 1991) suggesting that their mantle source has been modified by the elemental enrichment over the subduction zone. This enrichment could be ascribed to various fluids and melts (Wylie 1978; Prouteau et al. 2001). Despite of high LILE/HFSE and LILE/LREE ratios, which indicate a mantle source influenced by a mass transfer in a suprasubduction environment, these geochemical characteristics do not prove a close temporal relationship between the subduction of a lithospheric slab and partial melting of the modified mantle source. However, increased $\mathrm{Li}, \mathrm{F}$ and $\mathrm{Rb}$ contents can be also due to greisenization and the effect of primary 
enrichment in mantle and of secondary hydrothermal alteration in upper crust cannot be clearly separated.

We propose that the lamprophyre magmas in the Jáchymov ore district do not represent an extensive heat source but indicate pathways for subsequent migration of ore-forming fluids. This is confirmed by important hydrothermal alteration observed in nearly all lamprophyre dykes of the Jáchymov district. The diverse geochemical signature of lamprophyres within a single area together with the recurrent emplacement of silicic and mafic dykes suggest cyclic nature and simultaneous interaction of partial melting and fluid generation mechanisms.

\section{Conclusions}

The ore district of Jáchymov in the western Krušné hory hosts a Variscan assemblage of mafic and silicic dykes intersected by U- and Ag-bearing ore veins. The dykes include lamprophyres (kersantites, spessartites and minettes) affected by deuteric processes, which eradicated all magmatic olivine and pyroxenes. Mafic dykes show moderately increased $\mathrm{Cr}$ and $\mathrm{Ni}$ contents with high $\mathrm{mg \#}$ values indicative of a mantle source and high $\mathrm{K}, \mathrm{Rb}$, $\mathrm{Ba}$ and La contents, which suggest a crustal component introduced into the magma possibly via mantle metasomatism. The geochemistry of diorite porphyries shows a pronounced crustal contamination of lamprophyric magmas by crustal material due to mixing of a silicic magma with a mafic one. Mafic dykes have been influenced by hydrothermal solutions, which deposited epigenetic sulphides (mainly pyrrhotite and arsenopyrite) and carbonates. The $\mathrm{U}$ contents have not been notably increased in mafic dykes, while Th is enriched compared with the values reported for the dykes of similar composition in the literature. The occurrences of lamprophyres in the district testify to a connection of uranium deposits via a deep tectonic zone (the Jáchymov-Gera Lineament) with the mantle at the time of Variscan mineralization. Dykes and ore mineralization formed after the $\mathrm{K}$ metasomatism in the mantle had occurred. The massive deuteric alterations of lamprophyres coeval with ore mineralization emphasize the possible role of mantle fluids in transport of some elements, including economically important ore components.

Acknowledgments. This study has been supported by the Grant Agency of the Charles University (project 165/1998) and by the Ministry of Education of the Czech Republic (project MSM0021620855). We would like to thank Marta Pudilová for sample preparation for isotopic analysis and Karel Žák for measurements of oxygen isotopes. Milan Fišera and Jaromír Ulrych are gratefully thanked for careful reviews and helpful suggestions improving the manuscript. Critical comments and editorial notes by Vojtěch Janoušek are appreciated with many thanks.

\section{References}

Abdullaev KM (1957) Dykes and mineralisation. Gosudarstvennoe Nauchno Tekhnicheskoe Izdatelstvo Literatury po Geologii i Okhrane Nedr, Moscow, pp 1-232 (in Russian)

AČejev BN, Harlass E (1968) Zum Problem der Alterstellung von Lamprophyren im westlichen Erzgebirge. Geologie 17: 1178-1194

Ashley PM, Cоок NDJ, Hill RL, Kent AJR (1994) Shoshonitic lamprophyre dykes and their relation to mesothermal Au-Sb veins at Hillgrove, New South Wales, Australia. Lithos 32: 249-272

BACHINSKI SW, SсоTT RB (1979) Rare-earth and other trace element contents and the origin of minettes (mica lamprophyres). Geochim Cosmochim Acta 43: 93-100

Baier J, Audétat A, Keppler H (2008) The origin of the negative niobium tantalum anomaly in subduction zone magmas. Earth Planet Sci Lett 267: 290-300

BAUMANN L, GoRNY S (1964) Neue tektonische und petrographische Untersuchungsergebnisse in der Zinnlagerstätte Tannenberg-Mühlleiten. Freiberg Forsch H C181: 89-117

Baumann L, Kuschka E, Seifert T (2000) Lagerstätten des Erzgebirges. Enke, Stuttgart, pp 1-300

BERGMAN SC (1987) Lamproites and other potassium-rich igneous rocks: a review of their occurrence, mineralogy and geochemistry. In: Fitton JG, Upton BGJ (eds) Alkaline Igneous Rocks. Geol Soc London Spec Publ 30: pp 103-190

Dunlop D J, ÖZdemiR Ö (1997) Rock Magnetism: Fundamentals and Frontiers. Cambridge University Press, New York, pp 1-573

Edgar AD, Mitchell RH (1997) Ultra high pressure-temperature melting experiments on an $\mathrm{SiO}_{2}$-rich lamproite from Smoky Butte, Montana: derivation of siliceous lamproite magmas from enriched sources deep in continental crust. J Petrol 58: 457-477

EdGAR AD, VuKadinOvic D (1992) Implications of experimental petrology to the evolution of ultrapotassic rocks. Lithos 28: 205-220

Efremova C V (1983) Dykes and Endogenous Mineralisation. Nedra, Moscow, pp 1-223 (in Russian)

EsPerANZA S, Holloway JR (1987) On the origin of some mica-lamprophyres: experimental evidence from a mafic minette. Contrib Mineral Petrol 95: 207-216

FAURE G (1986) Principles of Isotope Geology, $2^{\text {nd }}$ ed., John Wiley and Sons, New York, pp 1-589 
Feng G, Weiming F, Yuejun W, Ming Z (2004) Origin of early Cretaceous calc-alkaline lamprophyres from the Sulu orogen in eastern China: implications for enrichment processes beneath continental collisional belts. Lithos 78: 291-305

Foley SF (1990) A review and assessment of experiments on kimberlites, lamproites and lamprophyres as guide to their origin. Proc Indian Acad Sci 99: 57-80

Foley SF (1992) Vein-plus-wall-rock melting mechanisms in the lithosphere and the origin of potassic alkaline magmas. Lithos 28: 435-453

Foley SF, Venturelli G, Green DH, Toscani L (1987) The ultrapotassic rocks: characteristics, classification and constrains for petrological models. Earth Sci Rev 24: $81-143$

Foley SF, Barth MG, Jenner GA (2000) Rutile/melt partition coefficients and an assessment of the influence of the mantle on the trace element characteristics of subduction zone magmas. Geochim Cosmochim Acta 64: 933-938

Hamidullah S, Bowes DR (1987) Petrogenesis of the appinite suite, Appin District, Western Scotland. Acta Univ Carol, Geol 31: 295-396

Holub FV (1997) Ultrapotassic plutonic rocks of the durbachite series in the Bohemian Massif: petrology, geochemistry and petrogenetic interpretation. Sbor geol Věd, Ložisk Geol Mineral 31: 5-26

Holub FV, ŠTEMPROK M (1999) Variscan lamprophyres and granitoid-related mineralizations: comparison of the Krušné hory-Erzgebirge and Central Bohemian batholiths. In Stanley C et al. (eds) Mineral Deposits: Processes to Processing. Balkema, Rotterdam, vol 1, pp 365-368

Hösel G, Breiter K (1995) Mineral Resources ErzgebirgeVogtland/Krušné hory, Map 2: Metals, Fluorite/Barite - occurrences and environmental impact, map 1: 100000. Sächsisches Landesamt für Umwelt und Geologie, Bereich Boden und Geologie, Freiberg and Czech Geological Survey, Prague

HROUDA F (1980) Magnetocrystalline anisotropy of rocks and massive ores: a mathematical model study and its fabric implications. J Struct Geol 2: 459-462

HROUDA F (1994) A technique for the measurement of thermal changes of magnetic susceptibility of weakly magnetic rocks by the CS-2 apparatus and KLY-2 kappabridge. Geophys J Int 118: 604-612

Hrouda F, CHLupÁČOVÁ M (1993) A petrophysical study, part II. Density, magnetic properties, elasticity, and radioactivity. In: Vrána S, Štědrá V (eds) Geological model of Western Bohemia in Relation to the Deep Borehole KTB in FRG. Czech Geological Survey, Prague, pp 1-110

Kempe U, Bombach K, Matukov D, Schlothauer T, Hutschenreuther J, Wolf D, Sergeev S (2004) $\mathrm{Pb} / \mathrm{Pb}$ and $\mathrm{U} / \mathrm{Pb}$ zircon dating of subvolcanic rhyolite as a time marker for Hercynian granite magmatism and $\mathrm{Sn}$ mineralization in the Eibenstock granite, Erzgebirge,
Germany: considering effects of zircon alteration. Miner Depos 39: 523-535

Komínek J, Chrt J, Landa O (1994) Uranium mineralization in the western Krušné hory Mts. (Erzgebirge) and the Slavkovský les region (Czech Republic). Monogr Series Mineral Deposits 31: 209-230

KonopÁseK J (1998) Formation and destabilization of the high pressure assemblage garnet-phengite-paragonite (Krušné hory Mountains): the significance of the Tschermak substitution in the metamorphism of pelitic rocks. Lithos 42: 269-284

Konopásek J, Schulmann K, Lexa O (2001) Structural evolution of the central part of the Krušné hory (Erzgebirge) during Variscan decompression. J Struct Geol 23: 1373-1392

KováŘííová P, Siebel W, Jelínek E, Štemprok M, Kachlík V, Holub FV, Blecha V (2007) Petrology, geochemistry and zircon ages for redwitzite at Abertamy, NW Bohemian Massif (Czech Republic): tracing the mantle component in Late Variscan intrusions. Chem Erde 67: 151-174

Kramer W (1976) Genese der Lamprophyre im Bereich der Fichtelgebirgisch-Erzgebirgischen Antiklinalzone. Chem Erde 35: 1-49

Kramer W (1988) Magmengenetische Aspekte der Lithosphärenentwicklung - Geochemich-petrologische Untersuchung basaltoider variszischer Gesteins-Formationen sowie mafischer und ultramafischer Xenolithe im nordöstlichen Zentraleuropa. Schriftenreihe Geol Wiss 26: pp 1-136

Kramer W, Seifert W (1994) Mica-lamprophyres and related volcanics of the Erzgebirge and metallogeny aspects. In Seltmann R, Kämpf H, Möller P (eds) Metallogeny of Collisional Belts. Czech Geological Survey, Prague, pp 159-165

Lange H, Tischendorf G, Pälchen W, Klemm I, Ossenkopf W (1972) Fortschrite der Metalogenie im Erzgebirge. Zur Petrographie und Geochemie der Granite des Erzgebirges. Geologie 21: 457-493

Langmuir CH, Vocke RD, Hanson GN, Hart SR (1978) A general mixing equation with applications to Icelandic basalts. Earth Planet Sci Lett 37: 380-392

LaUbe GC (1876): Geologie des böhmischen Erzgebirges, Archiv Naturwiss Landesforschung Böhmen. Prag, Teil 1, pp 1-208

Le Maitre RW (ed), Streckeisen A, Zanettin B, Le Bas MJ, Bonin B, Bateman P, Bellieni G, Dudek A, Efremova S, Keller J, Lameyre J, Sabine PA, Schmid R, Sørensen H, Wooley AR (2002). Igneous rocks. A Classification and Glossary of Terms. Cambridge University Press, Cambridge, pp 1-236

MAJER J (2004) Ore mining and the town of St. Joachimsthal/ Jáchymov at the time of Georgius Agricola. Geojournal 32: 91-99 
McDonough WF, Sun SS (1995) The composition of the Earth. Chem Geol 120: 223-253

McNeil AM, KerRich R (1986) Archaean lamprophyre dikes and gold mineralization, Ontario. The conjunction of LILE-enriched magmas, deep crustal structures and gold concentrations. Can J Earth Sci 23: 324-343

Mingram B, Kröner A, Hegner E, Krentz O (2004) Zircon ages, geochemistry, and $\mathrm{Nd}$ isotopic systematics of pre-Variscan orthogneisses from the Erzgebirge, Saxony (Germany), and geodynamic interpretation. Int J Earth Sci 93: 706-727

Mitchell RH (1994) The lamprophyre facies. Mineral Petrol 51: 137-146

MRŇA F, PAVLŮ D (1967) The deposits of Ag-Bi-Co-Ni-As formation in the Bohemian Massif. Sbor geol Věd, Ložisk Geol Mineral 9: 97-104 (in Czech)

Müller D, Groves DI (1997) Potassic Igneous Rocks and Associated Gold-copper Mineralization. Lecture Notes in Earth Sciences 56, Springer, Berlin, pp 1-238

Murphy JB, Pisarevsky SA, Nance RD, Keppie JD (2004) Neoproterozoic-Early Paleozoic evolution of peri-Gondwanan terranes: implications for Laurentia-Gondwana connections. Int J Earth Sci 93: 659-682

NAGata T (1961) Rock Magnetism. Maruzen, Tokyo, pp $1-350$

NĚMEC D (1973) Differentiation series of minettes in the Central Bohemian Pluton. J Geol 81: 632-642

Newton RJ, Bottrell SH, Dean SP, Hatfield D, Raiswell R (1995) An evaluation of the use of the chromous chloride reduction method for isotopic analysis of pyrite in rocks and sediments. Chem Geol 125: 317-320

Novák J, Pivec E, Holub FV, Štemprok M (2001) Greisenization of lamprophyres in the Krupka Sn-W district in the eastern Krušné hory/Erzgebirge, Czech Republic. In Piestrzynski et al. (eds) Mineral Deposits at the Beginning of the $21^{\text {st }}$ Century. Sweets and Zeilinger Publishers, Lisse, pp 485-488

Ondruš P, Veselovský F, Hloušek J, Skála R, VavŘín I, FrÝdA J, ČEJKA J, GabAšová A (1997) Secondary minerals of the Jáchymov (Joachimsthal) ore district. J Czech Geol Soc 42: 3-76

Ondruš P, Veselovský $\mathrm{F}$, Gabašová A, Drábek M, Dobeš P, Malý K, SeJKora J (2003) Ore-forming processes and mineral parageneses of the Jáchymov ore district. J Czech Geol Soc 48: 157-192

OwEN JP (2008) Geochemistry of lamprophyres from the Western Alps, Italy: implications for the origin of an enriched isotopic component in the Italian mantle. Contrib Mineral Petrol 155: 341-362

Peccerillo R, Taylor SR (1976) Geochemistry of Eocene calc-alkaline volcanic rocks from the Kastamonu area, northen Turkey. Contrib Mineral Petrol 58: 63-81

Pivec E, Holub FV, Lang M, Novák JK, Štemprok M (2002)

Rock-forming minerals of lamprophyres and associated mafic dykes from the Krušné hory/Erzgebirge (Czech Republic). J Czech Geol Soc 47: 23-32

Prelevic D, Foley SF, Cvetkovic V, Romer RL (2004) Origin of minette by mixing of lamproite and dacite magmas in Veliki Majdan, Serbia. J Petrol 45: 759-792

Prouteau G, Scaillet B, Pichavant M, Maury R (2001) Evidence for mantle metasomatism by hydrous silicic melts derived from subducted oceanic crust. Nature 410: $197-200$

Rовв L (2004) Introduction to Ore-forming Processes. Blackwell Publishing, Oxford, pp 1-373

Rock NMS (1977) The nature and origin of lamprophyres: some definitions, distinctions and derivations. Earth Sci Rev 13: 123-169

Rock NMS (1991) Lamprophyres. Blackie, Van Norstrand Reinhold, Glasgow, pp 1-285

Rock NMS, Groves DI, Perring CS, Golding SD (1989) Gold, lamprophyres, and porphyries: what does their association mean? Econ Geol Monogr 6: 609-625

Rollinson HR (2003) Using Geochemical Data: Evaluation, Presentation and Interpretation. Pearson Prentice Hall, Harlow, pp 1-352

Romer RL, Thomas R, Stein HJ, Rhede D (2007) Dating multiply overprinted Sn-mineralized granites - examples from the Erzgebirge, Germany. Miner Depos 42: $337-359$

RUDNICK RL, GAO S (2003) Composition of the continental crust. In: Rudnick RL (ed) The Crust. Treatise on Geochemistry 3, Elsevier, Amsterdam, pp 1-64

SATtRAn V (1965) Variscan igneous rocks of the Jáchymov ore district. Sbor geol Věd, Geol: 7-36 (in Czech)

SatTRAN V (1966) Tectonics of the Jáchymov ore district. Sbor geol Věd, Geol 10: 39-82 (in Czech)

SEIFERT T (1994) Zur Metallogenie der Lagerstätendistriktes Marienberg. Unpublished PhD Thesis, TU Bergakademie, Freiberg, pp 1-173

SEIFERT T (1997) Mantle metasomatism and associated late Variscan Sn and base metal mineralization in the Erzgebirge (Germany). In Hatton CJ (ed) Plumes, Plates and Mineralization, University of Pretoria, Pretoria, pp 89-90

SeIFERT T (1999) Relationship between late Variscan lamprophyres and hydrothermal vein mineralization in the Erzgebirge. In Stanley CJ et al. (eds) Mineral Deposits: Processes to Processing, Rotterdam, pp 429-432

SeIFERT T (2007) Genesis and Metallogenetic Potential of Permo-Carboniferous Lamprophyric Intrusions in the SaxoThuringian Zone of the Mid-European Variscides. Millpress Science Publishers, Rotterdam, Netherlands: pp 1-306

Seifert T, BAumann L (1994) On the metallogeny of the Central Erzgebirge anticlinal area (Marienberg district), Saxony, Germany. Monogr Series Mineral Deposits 31: 169-190

Seifert T, Kempe U (1994) Zinn-Wolfram-Lagerstätten und spät-variszische Magmatite des Erzgebirges. Beih Eur J Mineral 6: 125-172. 
Seifert W, Kramer W (2003) Accessory titanite: an important carrier of zirconium in lamprophyres. Lithos 71:81-98

Seifert T, Baumann L, Jung D (1992) On the problem of the relationship between $\mathrm{Sn}(-\mathrm{W})$ and quartz-polymetal mineralizations in the Marienberg deposit district. Z geol Wiss 20: 371-392

Siebel W (1993) Der Leuchtenberger Granit und seine assoziierten magmatische Gesteine: Zeitliche und Stoffliche Entwickulgsprozesse im Verlauf der Enstehung des Nordoberpfalz-Plutons. Unpublished PhD Thesis, Ruprechts Karls Universität, Heidelberg, pp 1-308

ShchUKIN SI (1974) Lamprophyres and ores. Geol Rud Mestorozh 16: 97-101 (in Russian)

Sun SS, McDonough WF (1989) Chemical and isotopic systematics of oceanic basalts: implications for mantle composition and processes. In: Saunders AD, Norry MJ (eds) Magmatism in the Ocean Basins. Geol Soc London Spec Pub 42: pp 313-345

ŠKVOR V (1974) Geology of the Czech part of the Krušné hory and Smrčiny. Knih Ústř Úst Geol 48, Czech Geological Survey, Prague: pp 1-120 (in Czech)

ŠKVOR V, SATTRAN V (1974) Krušné hory, western part, set of regional maps 1:50 000. Czech Geological Survey, Prague (in Czech)

ŠMeJKal V, Haur A, HLadíková J, VavŘín I (1974) Isotopic composition of sulphur of some sedimentary and endogenous sulphides in the Bohemian Massif. Čas Mineral Geol 19: 226-237

ŠTEMPROK M (1986) Petrology and geochemistry of the Czechoslovak part of the Krušné hory Mts. granite Pluton. Sbor Geol Věd, Ložisk Geol Mineral 27: 111-156

Štemprok M, Seltmann R (1994) The metallogeny of the Erzgebirge/Krušné hory. In: Seltmann R, Kämpf H, Möller P (eds) Metallogeny of Collisional Orogens. Czech Geological Survey, Prague, pp 61-69

Štemprok M, NovÁk JK, DAVID J (1994): The association between granites and tin-tungsten mineralization in the Krušné hory (Erzgebirge), Czech Republic. Monogr Series Mineral Deposits 31: 97-129

Štemprok M, Zouber V, Pivec E, Lang M (1996) Karlovy Vary Pluton: an example of a comagmatic sequence of Sn-bearing body, Freiberg Forsch H C467, 7-26

Štemprok M, Chlupáčová M, Holub FV, Novák J, Pivec E (1999) Petrology of mafic dykes from the Jáchymov ore district and their petrophysical properties. Zpr Geol Výzk v Roce 1998: 142-145 (in Czech)
Štemprok M, Holub FV, Chlupáčová M, Lang M, Novák JK, Pivec E (2000) Petrographic and geochemical study of lamprophyres in the Czech part of the Krušné hory batholith. Zpr Geol Výzk v Roce 1999: 80-82 (in Czech)

Štemprok M, Dolejš D, Müller A, Seltmann R (2008) Textural evidence of magma decompression, devolatilization and disequilibrium quenching: an example from the Western Krušné hory/Erzgebirge Pluton. Contrib Mineral Petrol 155: 93-109

Tarling DH, Hrouda F (1993) The Magnetic Anisotropy of Rocks. Chapman \& Hall, London, pp 1-217

Topinka I (1979) Ore geology of the Jáchymov ore field. Unpublished MSci. Thesis, Charles University, Prague (in Czech)

Troll G (1968) Gliederung der redwitzitischen Gesteine Bayerns nach Stoff- und Gefügemerkmalen. Teil 1. Die Typlokalität von Marktredwitz in Oberfranken. Abhand. Bayerische Akad Wissen Mat Naturwissen. Klasse 133: $1-86$

Veselý T (1986a) The Jáchymov uranium deposit. Krystalinikum 18: 133-165

VESELÝ T (1986b) Structure and significance of the ore knots in the uranium deposit of Jáchymov. Sbor geol Vẽd, Ložisk Geol Mineral 27: 7-109 (in Czech)

Watznauer A (1964) Der heutige Stand des Lamprophyrsproblems. Geologie 12: 812-820

Wimmenauer W (1973) Granites and lamprophyres. Bull Soc Géol France 15: 195-198

Wunder B, Melzer S (2003) Experimental evidence on phlogopitic mantle metasomatism induced by phengite dehydratation. Eur J Mineral 15: 641-647

Wyllie PJ (1978) Mantle fluid compositions buffered in peridotite- $\mathrm{CO}_{2}-\mathrm{H}_{2} \mathrm{O}$ by carbonates, amphibole and phlogopite. J Geol 86: 687-713

WyMAn DA, KerRich R (1988) Lamprophyres as source of gold. Nature 332: 209-210

Zoubek V, ŠTemprok M, Vyskočll V (1996) Geotectonic position of the Krušné hory (Erzgebirge) tin-bearing batholith in the geological structure of Europe (a review). Freiberg Forsch H C467: 59-85

ŽÁa K, Štemprok M, Holub FV, JaČKová I, NovÁk JK, VeseLOVSKÝ F (2001) Isotope composition of sulfur in sulfides, of carbon and oxygen in carbonates from mafic dyke rocks in the Czech part of the Krušné hory/Erzgebirge area. Zpr Geol Výzk v Roce 2000: 111-114 (in Czech) 


\section{Appendix 1}

\section{Gamma spectrometry - methodology}

The samples crushed to grains under $3 \mathrm{~mm}$ were closed in plastic cases, and when equilibrium between radium and radon was attained they were placed to a shielded $\mathrm{NaI}(\mathrm{Tl})$ detector $4 "$ in diameter and $4 "$ in height, with energy resolution of $7.9 \%(662 \mathrm{keV})$. Spectra measured with a multichannel spectrometer RT-50 were evaluated by comparison with spectra of the IAEA standards from Vienna and IIZ standards from Prague. The measuring time was 20 minutes, sample mass range close to $400 \mathrm{~g}$. As the $\mathrm{U}$ content obtained on the basis of low-power gamma radiation of ${ }^{234} \mathrm{Th}$ and ${ }^{235} \mathrm{U}$ isotopes is not very accurate, the content of $\mathrm{U}(\mathrm{Ra})$ (equivalent Uranium) was determined using gamma rays of ${ }^{222} \mathrm{Rn}$ daughter progeny as was the content of Th using ${ }^{220} \mathrm{Rn}$ progeny. If radioactive equilibrium was attained and preserved in the decay chain, then the values of $U$ and $U(R a)$ should be equal. However, differences frequently occured in altered rocks. Standard deviations of a single determination of a little radioactive rock was $\pm 0.3 \mathrm{ppm}$ for $\mathrm{Th}$, $\pm 0.5 \mathrm{ppm}$ for $\mathrm{U}, \pm 0.1 \mathrm{ppm}$ for $\mathrm{U}(\mathrm{Ra})$ and $\pm 0.04 \%$ for $\mathrm{K}$. 